UII norden

Den nordiska konventionen om arv, testamente och boutredning (antagen i Köpenhamn 19.11.1934) 

4 norden 



\section{Den nordiska konventionen om arv, testamente och boutredning (antagen i Köpenhamn 19.11.1934)}

En översyn av konventionsregleringen föreslagen av den nordiska expertgruppen för familjerättsfrågor 
Den nordiska konventionen om arv, testamente och boutredning

(antagen i Köpenhamn 19.11.1934)

En översyn av konventionsregleringen föreslagen av den nordiska expertgruppen för

familjerättsfrågor

ISBN 978-92-893-2541-7

http://dx.doi.org/10.6027/TN2013-528

TemaNord 2013:528

(C) Nordiska ministerrådet 2013

Layout: Hanne Lebech/NMR

Omslagsfoto: ImageSelect

Tryck: Rosendahls-Schultz Grafisk

Upplaga: 330

Printed in Denmark

Denna rapport är utgiven av med finansiellt stöd från Nordiska ministerrådet. Innehållet i rapporten avspeglar inte nödvändigtvis Nordiska ministerrådets synpunkter, åsikter eller rekommendationer.

www.norden.org/sv/publikationer

\section{Det nordiska samarbetet}

Det nordiska samarbetet är ett av världens mest omfattande regionala samarbeten. Det omfattar Danmark, Finland, Island, Norge och Sverige samt Färöarna, Grönland och Åland.

Det nordiska samarbetet är politiskt, ekonomiskt och kulturellt förankrat och är en viktig partner i europeiskt och internationellt samarbete. Den nordiska gemenskapen arbetar för ett starkt Norden i ett starkt Europa.

Det nordiska samarbetet ska stärka nordiska och regionala intressen och värderingar i en global omvärld. Gemensamma värderingar länderna emellan bidrar till att stärka Nordens ställning som en av världens mest innovativa och konkurrenskraftiga regioner.

\section{Nordiska ministerrådet}

Ved Stranden 18

DK-1061 København K

Telefon $(+45) 33960200$

www.norden.org 


\section{Innehåll}

1. Nordiskt samarbete inom internationell familje- och arvsrätt - bakgrund och framtidsvisioner.

2. Arvskonventionens tillkomst, tillämpningsområde och struktur............................... 11

3. Översikt över nuvarande konventionsreglering ......................................................... 13

4. Behörighet, tillämplig lag samt erkännande och verkställighet enligt

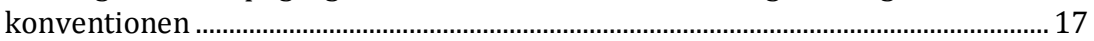

$4.1 \quad$ Behörig myndighet....................................................................................... 17

4.2 Tillämplig lag: huvudregeln och den så kallade femårsregeln ....................... 18

4.3 Om efterlevande makes rättsställning - lagvalsfrågor och

ländernas materiella arvsrätt........................................................................... 19

4.4 Erkännande och verkställighet.......................................................................... 23

5. Om allmänt tillämpliga internationellt privaträttsliga regler i de nordiska länderna - särskilt lagval ........................................................................................... 25

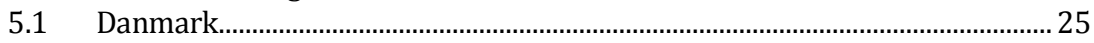

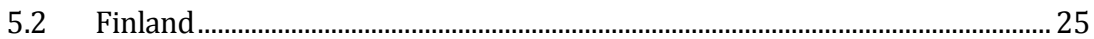

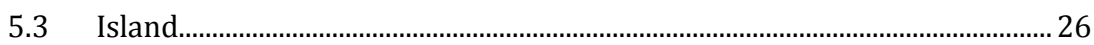

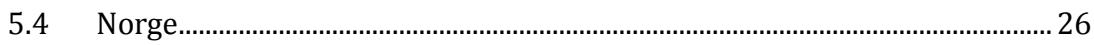

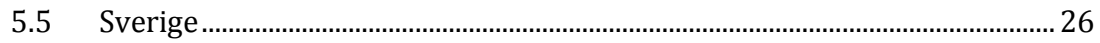

6. Mot en moderniserad arvskonvention......................................................................... 27

6.1 Senare rättsutveckling och praktiska behov .................................................... 27

6.2 Relationen till EU:s arvsförordning .................................................................... 29

6.3 Vilka situationer avses omfattas av de reviderade nordiska

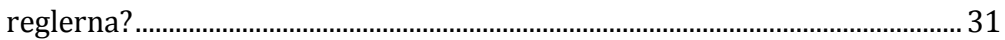

6.4 Vilken stats lag ska bestämma över arvet när arvlåtaren inte har

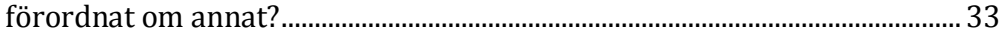

6.5 Arvlåtarens rätt att bestämma tillämplig lag.................................................... 35

6.6 Efterlevande makes rättsställning - finns det behov att samordna tillämplig lag för arv med tillämplig lag för makars

förmögenhetsförhållanden?

6.7 Hur förhåller sig konventionen och förslaget till personer av samma kön som har ingått äktenskap, registrerade partner och samboende personer?

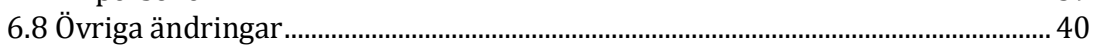


7. De föreslagna ändringarna jämte motivering .............................................................. 41

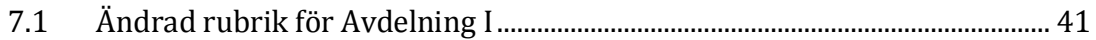

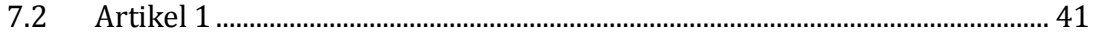

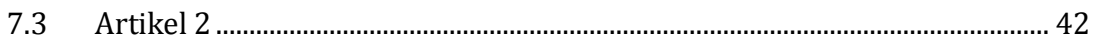

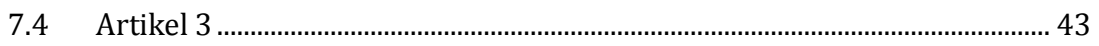

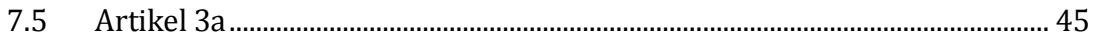

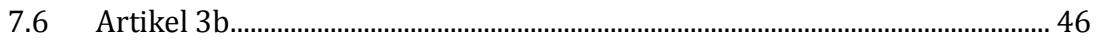

7.7 Artikel 4 - (upphävd 1975) ........................................................................... 47

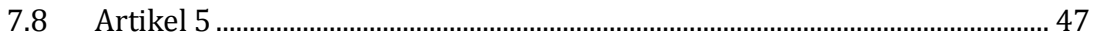

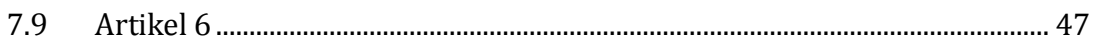

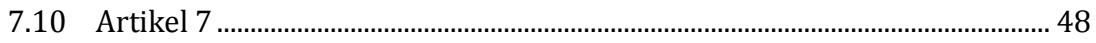

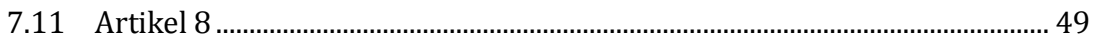

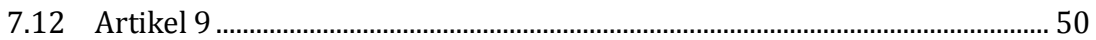

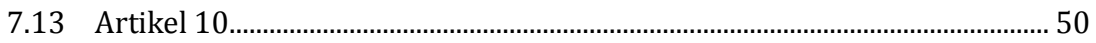

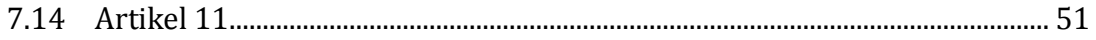

7.15 Artikel 12

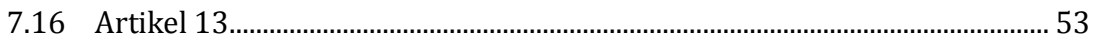

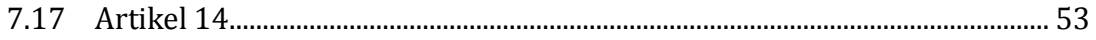

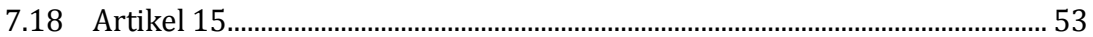

7.19 Artikel 16 ................................................................................................... 54

7.20 Oförändrad rubrik för Avdelning II Den dödes gäld........................................... 54

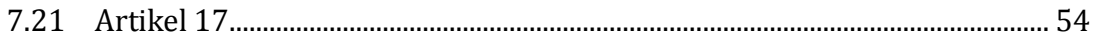

7.22 Artikel 18......................................................................................................... 55

7.23 Oförändrad rubrik för Avdelning III Boutredning, bodelning och

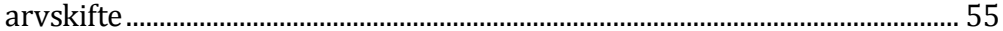

7.24 Artikel 19...................................................................................................... 56

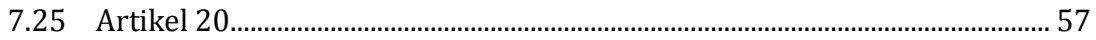

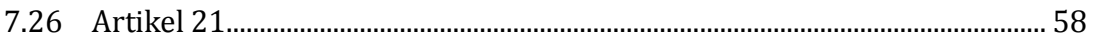

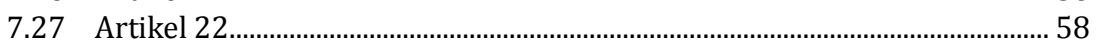

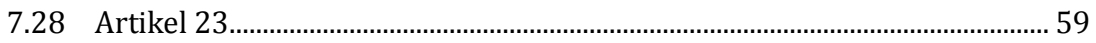

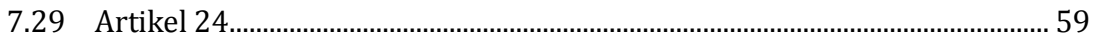

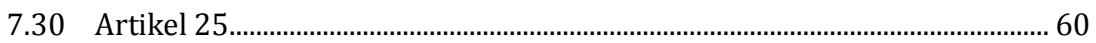

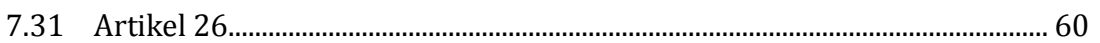

7.32 Oförändrad rubrik för Avdelning IV Allmänna bestämmelser ....................... 60

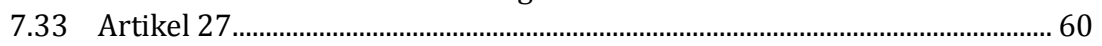

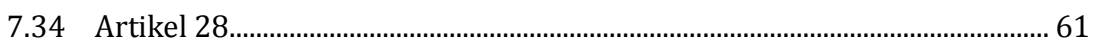

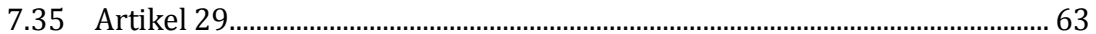

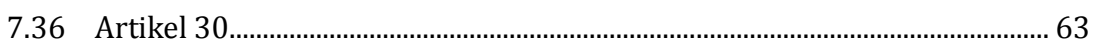

8. Bilaga: Överenskommelse om ändring i den nordiska arvskonventionen

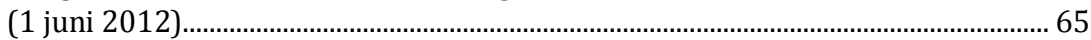




\section{Nordiskt samarbete inom internationell familje- och arvsrätt - bakgrund och framtidsvisioner}

I början av 1900-talet kunde de nordiska länderna komma överens om grundläggande principer avseende hur en modern, materiell familjerätt, särskilt äktenskapsrätt, ska se ut. Det framgångsrika samarbetet kompletterades på 1930-talet genom antagandet av tre i sak omfattande familje- och arvsrättsliga konventioner mellan länderna, avsedda att underlätta för nordiska medborgare att flytta mellan länderna. I internationell jämförelse framstår dessa konventioner än i dag i väsentliga delar som progressiva och enkla att tillämpa, och de konkretiserar innebörden av ömsesidigt förtroende mellan de nordiska länderna inom det familje- och arvsrättsliga området. Regleringarna återspeglar och är anpassade till ländernas materiella familje- och arvsrätt.

Numera är tre av länderna (Danmark, Finland och Sverige) medlemsstater i Europeiska unionen (EU) som sedan 1999 har lagstiftningskompetens rörande gränsöverskridande familje- och arvsfrågor. Medan Finland och Sverige deltar i detta samarbete har Danmark beviljats undantag att inte omfattas av det. Nya, av EU antagna förordningar har gett de nordiska länderna anledning att se över de egna konventionerna på området. År 2001 justerades ett antal bestämmelser i 1962 års konvention (ursprungligen från 1931) angående indrivning av underhållsbidrag. Samma år såg man över bland annat bestämmelserna avseende domsrätt i äktenskapsmål i 1931 års konvention innehållande internationellt privaträttsliga bestämmelser om äktenskap, adoption och förmynderskap. I januari 2006 ingicks en överenskommelse om ändring av den sistnämnda konventionens bestämmelser avseende makars förmögenhetsförhållanden.

Omedelbart efter det sistnämnda arbetet tog länderna itu med uppgiften att modernisera bestämmelserna i 1934 års konvention om arv, testamente och boutredning. Den nordiska expertgruppen för familjerättsfrågor, där samtliga nordiska länder är representerade, har haft ansvaret för översynen, liksom för tidigare här angivna revideringar av de nordiska familjerättskonventionerna. Översynen har begränsats till konventionens mest grundläggande bestämmelser om tillämplig lag beträffande vilka ändringsbehovet bedömts vara störst. Enligt expert- 
gruppens bedömning är konventionsregleringen i övrigt väsentligen välfungerande; gruppen känner i vart fall inte till några särskilda olägenheter som skulle ha uppstått vid konventionens tillämpning. Utgångspunkten har varit att förutom nya lagvalsregler endast föreslå nödvändiga moderniseringar av språket, utan att någon ändring i sak varit avsedd. Dock föreslås även uppenbart obsoleta bestämmelser, eller delar i någon bestämmelse, bli upphävda. I vissa fall har expertgruppen haft svårt att bedöma huruvida en konventionsbestämmelse fortfarande fyller en funktion. I dessa fall föreslås ingen ändring i sak, men expertgruppen uppmanar länderna att återkomma till de identifierade frågorna vid ett senare tillfälle.

Det är resultaten av arbetet med revidering av den nordiska arvskonventionen som redovisas i denna promemoria. Expertgruppen slutförde sitt ursprungliga arbete i slutet av år 2009, kort efter att EUkommissionen kommit med ett förslag till Europaparlamentets och rådets förordning om behörighet, tillämplig lag, erkännande och verkställighet av domar och officiella handlingar i samband med arv och om inrättande av ett europeiskt arvsintyg. ${ }^{1}$ När arbetet med EU:s arvsförordning närmade sitt slut begärde Sverige, stött av Finland, ett undantag för att länderna emellan få tillämpa den nordiska arvskonventionen i en reviderad lydelse. Då frågan om undantaget förhandlats färdigt inom EU beslutade den nordiska expertgruppen att återuppta sitt arbete med översynen av den nordiska konventionen, i syfte att både ta till vara de fördelar som undantaget medför ${ }^{2}$ och att föra sitt förslag till nya lagvalsregler mer i linje med lagvalsreglerna i EU:s arvsförordning vars slutgiltigta text antogs den 4 juli 2012.

Expertgruppens nu framlagda nya förslag 3 innebär, med andra ord, ett förslag om att de enkla och välfungerande nordiska bestämmelserna om erkännande och verkställighet fortsätter att vara tillämpliga de nordiska länderna emellan, liksom bestämmelserna avseende administrativa förfaranden kring en kvarlåtenskaps överföring, samtidigt som konventionens

\footnotetext{
${ }^{1}$ Bryssel den 14.10.2009, KOM(2009) 154 slutlig. 2009/0157 (COD).

2 Det beviljade undantaget i artikel 75.3 i arvsförordningen har följande lydelse.

Denna förordning ska inte hindra tillämpningen av konventionen av

den 19 november 1934 mellan Sverige, Danmark, Finland, Island och Norge innehållande internationella privaträttsliga bestämmelser om arv, testamente och boutredning, ändrad genom en mellanstatlig överenskommelse mellan dessa stater av den 1 juni 2012, av de medlemsstater som är parter $i$ konventionen, $i$ den utsträckning som konventionen föreskriver

a) regler avseende förvaltningen av dödsboet såsom anges $i$ konventionen och medverkan av myndigheter $i$ de fördragsslutande staterna, och

b) enklare och snabbare förfaranden för erkännande och verkställighet av domar i samband med arv.

3 Den förklarande rapporten med förslaget färdigställdes den 29 mars 2012. Efter det att Europaparlamentets och rådets förordning (EU) nr 650/2012 av den 4 juli 2012 om behörighet, tillämplig lag, erkännande och verkställighet av domar samt godkännande och verkställighet av officiella handlingar i samband med arv och om inrättandet av ett europeiskt arvsintyg (arvsförordningen) antogs, har förklarande rapporten uppdaterats så att hänvisningarna till arvsförordningen överensstämmer med den slutgiltiga lydelsen av förordningen.
} 
grundläggande lagvalsregler justerats så att de i allt väsentligt motsvarar bestämmelserna i arvsförordningen. Enligt expertgruppens mening uppnås på detta sätt en välbalanserad och tillräckligt modern reglering som är ägnad att främja rörligheten mellan länderna. Förslaget kan även förväntas medföra ökad rättssäkerhet för de berörda personerna avseende vilka regler som gäller. 



\section{Arvskonventionens tillkomst, tillämpningsområde och struktur}

Konventionen mellan de fem nordiska länderna om arv, testamente och boutredning undertecknades i Köpenhamn den 19 november 1934. Efter deposition av ratifikationsinstrumenten den 14 juni 1935 trädde konventionen i kraft den 1 januari 1936. De senaste ändringarna är från 1970talet då man dels såg över bestämmelserna angående formen för testamentariska förordnanden, dels justerade villkoren för erkännande och verkställighet av i ett annat nordiskt land meddelade avgöranden om arv och testamente. Den först nämnda ändringen aktualiserades i anledning av överväganden om tillträde till 1961 års Haagkonvention om lagkonflikter i fråga om formen för testamentariska förordnanden. ${ }^{4}$ Den andra ändringen föranleddes av ländernas överenskommelse år 1977 om en ny konvention om erkännande och verkställighet av nordiska domar på privaträttens område. ${ }^{5}$ Det danska utrikesministeriet är depositarie.

Tillämpningsområdet för konventionen avser i huvudsak situationer där den avlidne var medborgare i en nordisk stat och hade hemvist i en annan nordisk stat vid tidpunkten för dödsfallet. I något fall synes konventionen dock även omfatta situationer där den avlidne hade hemvist i samma stat där han eller hon var medborgare. ${ }^{6}$ I konventionstexten hänvisas sålunda till såväl situationer där den avlidne var medborgare $i$ en fördragsslutande stat med hemvist $i$ en annan fördragsslutande stat som situationer där den avlidne var medborgare i fördragsslutande stat med hemvist i samma fördragsslutande stat. Konventionens tillämpningskriterier är att se som en kompromiss mellan nationalitetsprincipen, enligt vilken arvsfrågorna bör bedömas med utgångspunkt i den avlidnes sista medborgarskap, och hemvistprincipen, enligt vilken den avlidnes sista hemvist i stället bör vara utgångspunkt. Vid tiden för konventionens utarbetande var nämligen nationalitetsprinci-

\footnotetext{
4 De danska motiven finns i Folketingstidende 1973-74, Tillæg A, sp. 540ff, de finska motiven finns i RP nr 171/1975, de norska motiven finns i kgl. Res. 1 februari 1974 och de svenska motiven finns i prop. 1973:175. ${ }^{5}$ De danska motiven finns i Folketingstidende 1976-77, Tillæg A, sp. 704ff, de norska motiven finns i Ot.prp.nr.39 (1976-1977), de finska motiven finns i RP nr 37/1977 och de svenska motiven finns i prop. 1976/77:128.

${ }^{6}$ Detta torde gälla t.ex. angå ende artikel 19.
} 
pen väl förankrad i både finsk och svensk rättspraxis vid bedömningen av internationella arvsfrågor, medan hemvistprincipen tillämpades i de övriga nordiska länderna.

Konventionen består ursprungligen av 30 artiklar, indelade i fyra avdelningar. I den första avdelningen (art. 1-16) finns bestämmelser om tillämplig lag i frågor om arv, testamente och oskiftat bo. Den andra avdelningen (art. 17-18) innehåller särskilda regler om den dödes skulder. I avdelning tre (art. 19-26) finns i huvudsak behörighetsregler för boutredning, bodelning och arvskifte. I avdelning fyra (art. 27-30) är allmänna bestämmelser av olika slag samlade, inklusive den viktiga regeln om ömsesidigt erkännande och verkställighet av domar och förlikningar avseende arv, testamente, m.m. Konventionen kompletteras med ett slutprotokoll som länderna antog i samband med konventionens undertecknande. 


\section{3. Översikt över nuvarande konventionsreglering}

- Art. 1-3 innehåller bestämmelser om tillämplig lag i materiella frågor om arv, testamente och oskiftat bo. I art. 3 finns också särskilda regler om behörighet beträffande tillsyn m.m. och om bouppteckning i situationer där boet behålls oskiftat med tillämpning av ett annat lands lag.

- Art. 4 är upphävd sedan 1975. Den gäller dock fortfarande i förhållande till Färöarna.

- Art. 5 föreskriver att art. 2-3 ska tillämpas också i fråga om adoptivbarn.

- Art 6 är en regel om att den som enligt art. 1-3 begär tillämpning av medborgarskapslandets lag har bevisbördan för att förutsättningarna för det är uppfyllda och för innehållet i denna lag. I ett slutprotokoll har konventionsstaterna också åtagit sig att genom respektive ministerium lämna upplysningar om gällande rätt.

- Art. 7 hänvisar i fråga om de materiella bodelningsfrågorna till den nordiska äktenskapskonventionens lagvalsregler.

- Art. 8 anvisar tillämplig lag för bedömning av ett testamentes giltighet till formen. Bestämmelsen är anpassad till 1961 års Haagkonvention, vilken Danmark, Finland, Norge och Sverige har tillträtt.

- Art. 9 anger tillämplig lag för bedömning av testationshabilitet.

- Art. 10 anger tillämplig lag för bedömning av testamentes ogiltighet på grund av brister beträffande viljeförklaringen.

- Art. 11 innebär att finska eller svenska bestämmelser om bevakning och klander av testamente, respektive norska tidsfrister avseende testamente, alltid ska tillämpas om den avlidne hade hemvist i landet.

- Art. 12 föreskriver att frågor om arvsavtal, gåva för dödsfalls skull och förskott på arv bedöms enligt lagen i det land där arvlåtaren hade hemvist då rättshandlingen företogs.

- Art. 13 gör lex rei sitae tillämplig för speciella rättigheter till fast egendom, t.ex. i fråga om fideikommiss.

- Art. 14 föreskriver att ett förbehåll vid adoption om testationsfrihet trots adoptionen (tidigare möjligt i Danmark och Island) ska gälla i alla konventionsstater.

- Art. 15 anger tillämplig lag för fråga om förverkande av arvsrätt.

- Art. 16 anger tillämplig lag för frågan om preskription av arvsrätt. 
- Art. 17 anger tillämplig lag för fråga om ansvar för den avlidnes skulder, fullgörande av legat eller ändamålsbestämmelse i testamente och för underhåll för barn utom äktenskap.

- Art. 18 anger att en proklama (kallelse att göra fordringar mot boet gällande) har verkan mot en känd borgenär med hemvist i en annan nordisk stat endast om borgenären får vetskap om proklaman och dess verkan.

- Art. 19 innehåller de grundläggande reglerna om att det är myndigheterna i den stat där den avlidne hade hemvist vid sin död som är behöriga i frågor om boutredning, bodelning och arvskifte. Behörigheten omfattar all den avlidnes egendom, oavsett i vilken fördragsslutande stat den finns. Är det fråga om ett bo som en efterlevande make innehaft som oskiftat, ska förfarandet ske i den sist avlidne makens sista hemvistland.

- Art. 20 anger tillämplig lag för frågor om efterlevande makes rätt att ta ut viss egendom vid bodelning.

- Art. 21 innehåller huvudregeln som innebär att internationell behörighet i tvister om arv, testamente, efterlevande makes rätt eller fordran mot dödsboet ligger hos domstolarna i den stat där boutredning, bodelning och arvskifte sker. Parterna kan genom avtal få tvisten prövad i en annan konventionsstat. Sådan prorogation kan inte ske om på grund av hemvistlandets lag boutredning ska göras av offentlig myndighet, testamentsexekutor eller boutredningsman. Prorogation är också utesluten om tvisten rör klander av testamente efter någon som hade hemvist i Sverige eller Finland, eller klander av bodelning eller arvskifte efter någon som hade hemvist i Finland.

- Art. 22 innehåller bestämmelser om bistånd till boutredning i annan konventionsstat beträffande egendom som finns i landet.

- Art. 23 bestämmer att begränsningarna av möjligheten till specialexekution under offentligt skifte i Danmark, Island och Norge ska tillämpas också för egendom som finns i annan konventionsstat, med undantag för utmätning för skatt och uttagande ur säkerhet.

- Art. 24 hänvisar i fråga om förmånsrätt vid offentligt skifte i Danmark, Island och Norge till bestämmelserna i 1933 års nordiska konkurskonvention (i förhållandet mellan Danmark, Finland, Norge och Sverige numera i ny lydelse).

- Art. 25 föreskriver att krav på inskrivning (tinglysning) av en överlåtelse eller en utmätning som förutsättning för att den ska kunna åberopas mot dödsboet inte tillämpas beträffande egendom som finns i annan konventionsstat. Bestämmelsen har en motsvarighet i den nordiska konkurskonventionen.

- Art. 26 är en hjälpregel för att fastställa i vilken stat vissa särskilda typer av egendom (fordran grundad på presentationspapper, annan fordran samt registrerade fartyg och luftfartyg) ska anses finnas.

- Art. 27 föreskriver att ett domstolsbeslut i en konventionsstat om omhändertagande av boet för utredning och skifte eller om 
efterlevande makes rätt att sitta i oskiftat bo ska gälla i alla konventionsstater.

- Art. 28 föreskriver tillämpning av lagen i den konventionsstat där erkännande eller verkställighet begärs ifråga om dom eller förlikning avseende rätt till arv eller testamente, efterlevande makes rätt, boutredning eller skifte i anledning av dödsfall eller ansvar för den avlidnes skulder.

- Art. 29 är en övergångsbestämmelse enligt vilken konventionen inte är tillämplig när arvlåtaren dött före konventionens ikraftträdande.

- Art. 30 innehåller bestämmelser om ratifikation, ikraftträdande och uppsägning.

I det till konventionen bifogade slutprotokollet kom länderna överens om förfarandet vid begäran om upplysningar angående innehållet i någon av staterna gällande lag. En sådan begäran framställs till justitieministeriet, utom i Sverige där den framställs till utrikesdepartementet. 



\section{Behörighet, tillämplig lag samt erkännande och verkställighet enligt konventionen}

Nedan återges konventionens huvudregler vad gäller bedömningen av internationell behörighet, valet av tillämplig lag samt erkännande och verkställighet av avgöranden.

\subsection{Behörig myndighet}

"Boutredning, bodelning och arvskifte efter medborgare i fördragsslutande stat, som vid sin död hade hemvist i sådan stat, skola äga rum i enlighet med lagen i den stat, där den döde hade hemvist, och, såvitt enligt nämnda lag domstol skall medverka, ankomma på domstol i den staten." (Art. 19 första stycket)

"Boutredning, bodelning och arvskifte skola omfatta till boet hörande egendom jämväl i annan fördragsslutande stat." (Art. 19 tredje stycket)

"Tvist om arv eller testamente efter medborgare i fördragsslutande stat, som hade hemvist i sådan stat, eller om efterlevande makes rätt eller om fordran mot dödsboet skall upptagas av domstol i den stat, vars lag enligt artikel 19 skall gälla i fråga om dödsbobehandlingen." (Art. 21 första stycket)

"Äro parterna därom ense, må tvisten upptagas i annan fördragsslutande stat, dock ej där boet är föremål för behandling av arvsdomstol eller av testamentsexekutor eller av domstol förordnad boutredningsman eller skiftesman eller tvisten avser klander av bodelning eller arvskifte i sådant bo eller av testamente efter någon som hade hemvist $\mathrm{i}$ Finland eller Sverige, eller av bodelning eller arvskifte efter någon som hade hemvist i Finland." (Art. 21 andra stycket)

Grundregeln om den internationella behörigheten är att det är myndigheterna i den nordiska stat där den avlidne hade hemvist vid sin död som är behöriga i fråga om boutredning, bodelning och arvskifte samt tvister om arv, testamente, efterlevande makes rätt eller fordran mot dödsboet (art. 19 och art. 21). Det finns vissa begränsade möjligheter för tvistande parter att komma överens om att prövningen ska ske i en annan nordisk stat (art. 21 andra stycket). Universali- 
tetsprincipen (enhetsprincipen) tillämpas, det vill säga behörigheten omfattar all den avlidnes egendom, oavsett vilken fördragsslutande stat den finns i (art. 19 tredje stycket).

\subsection{Tillämplig lag: huvudregeln och den så kallade femårsregeln}

"Hade medborgare i fördragsslutande stat vid sin död hemvist i annan sådan stat, gälle i fråga om rätt till arv efter honom lagen i sistnämnda stat. Där den döde icke vid dödsfallet sedan minst fem år hade hemvist $\mathrm{i}$ den staten, skall dock lagen i hans hemland vinna tillämpning, såframt det yrkas av någon arvinge eller testamentstagare, vars rätt därav beror. Skulle enligt hemlandets lag arvet tillfalla staten, må sådant yrkande ej väckas." (Art. 1 första stycket)

"Yrkandet om tillämpning av hemlandets lag skall väckas inom sex månader från dödsfallet eller, om arvskifte äger rum efter utgången av sagda tid, sist vid arvskiftet. Sedan arvskifte skett, må ej i något fall den som deltagit i skiftet väcka sådant yrkande." (Art. 1 andra stycket)

Tillämplig lag för den materiella frågan om rätt till arv är enligt huvudregeln lagen i den nordiska stat där den avlidne hade hemvist vid sin död (art. 1 första stycket). Om hemvistet hade varat kortare tid än fem år, kan en arvinge eller testamentstagare vars rätt påverkas av det yrka att lagen i den nordiska stat där den avlidne var medborgare i stället tillämpas. Yrkandet måste framställas inom sex månader från dödsfallet eller senast vid arvskiftet (art. 1 andra stycket).

Som exempel kan ges följande fall. Den förmögne norske medborgaren Arne hade vid sin död hemvist i Sverige sedan tre år. Arne har upprättat ett testamente som ger hans bror Helge hela kvarlåtenskapen, med följden att Arnes son och enda arvinge Torstein inte kan få ut sin laglott. Enligt huvudregeln är svensk rätt - Ärvdabalken - tillämplig på rätten till arv efter Arne. Svensk rätt ger Torstein rätt att påkalla jämkning av testamentet för att få ut sin laglott (= halva lagenliga arvsandelen). För att hindra detta gör Helge omgående bruk av femårsregeln och yrkar tillämpning av norsk lag. Torstein får nöja sig med det norska laglottsskyddet som är begränsat till 1 miljon norska kronor. - Om i stället Arne varit mindre förmögen med en kvarlåtenskap på ett värde motsvarande 1 miljon norska kronor skulle Torstein - genom att yrka tillämpning av norsk lag - kunna säkerställa sig ett laglottsskydd på $2 / 3$ av kvarlåtenskapens värde, i stället för det mer begränsade svenska laglottsskyddet ( $1 / 2$ av kvarlåtenskapen).

Tillämplig lag för själva förfarandet vid boutredning, bodelning och arvskifte är alltid lagen i det land där förrättningen äger rum, dvs. lex fori (art. 19). 


\subsection{Om efterlevande makes rättsställning - lagvalsfrågor och ländernas materiella arvsrätt}

\subsubsection{Utgångspunkten}

Vid tiden för konventionens utarbetande fanns det betydelsefulla skillnader mellan länderna vad gäller efterlevande makes rätt till kvarlåtenskap, särskilt rätten att sitta i oskiftat bo. För att komma till rätta med dessa olikheter innehåller konventionen olika regler om tillämplig lag beroende på om den avlidne har efterlämnat bröstarvinge eller inte. Reglerna avser i första hand att gynna den efterlevande maken på så sätt att denne i möjligaste mån säkerställs rätten till oskiftat dödsbo när sådan rätt finns antingen enligt lagen i den avlidnes hemviststat eller medborgarskapsstat. Det bör noteras att konventionen utgår från att bodelningsfrågorna, med något undantag, bedöms enligt den stats lag som anvisas av bestämmelserna om makars förmögenhetsförhållanden i den nordiska äktenskapskonventionen, se art. 7 i arvskonventionen. Det innebär med andra ord att konventionen syftar på situationer där både de materiella bodelningsfrågorna och de materiella arvsfrågorna är att bedöma enligt de fördragsslutande staternas lagar.

Efterlevande makes rättsställning regleras särskilt i flera artiklar av konventionen, såsom art. 1 tredje stycket, art. 2, art. 3, liksom även i art. 5-7, art. 19 andra stycket och art. 20.

\subsubsection{Om rätten att sitta i oskiftat bo i avsaknad av bröstarvinge}

"Bestämmelserna i första och andra styckena om rätt till arv skola tilllämpas också i fråga om efterlevande makes rätt att sitta i oskiftat bo, när bröstarvinge ej finnes, och på sådan rätt till bidrag till uppehälle och utbildning ur kvarlåtenskap som tillkommer arvinge eller efterlevande make. Detsamma gäller rätt för efterlevande make att ur boet uttaga egendom intill visst penningvärde." (Art. 1 tredje stycket)

Huvudregeln om tillämpningen av hemvistlandets lag gäller alltså också i fråga om efterlevande makes rätt att sitta i oskiftat bo när det inte finns någon bröstarvinge, om efterlevande makes eller arvinges rätt att få ut bidrag till uppehälle och utbildning ur kvarlåtenskapen och om efterlevande makes rätt att få ut visst belopp ur boet (art. 1 tredje stycket). Femårsregeln står till förfogande även i dessa fall. 


\subsubsection{Om rätten att sitta i oskiftat bo tillsammans med bröstarvinge}

"Hade den döde hemvist i fördragsslutande stat, vars lag tillägger efterlevande make rätt att sitta i oskiftat bo med bröstarvinge, skall den lagen vinna tillämpning, ändå att den döde var medborgare i annan fördragsslutande stat. Där den döde icke sedan minst fem år hade hemvist $\mathrm{i}$ förstnämnda stat, äge dock bröstarvinge att, genast eller vid en senare tidpunkt, påkalla bodelning, såvitt dylik rätt enligt lagen i den dödes hemland tillkommer honom. Sådan rätt äge ej rum, när efterlevande maken vid äktenskapets ingående var medborgare i den stat, där den döde hade hemvist." (Art. 2)

"Hade den döde hemvist i fördragsslutande stat, vars lag ej tillägger efterlevande make rätt att sitta i oskiftat bo med bröstarvinge, men förelåg sådan rätt enligt lagen i den dödes hemland, skall den lagen vinna tillämpning, där den döde ej sedan fem år hade hemvist i förstnämnda stat." (Art. 3, förkortad.)

Av de ovan citerade bestämmelserna följer att lagen i den avlidnes sista hemvistland tillämpas om den ger efterlevande maken rätt att sitta i oskiftat bo med bröstarvinge (art. 2). Om hemvistet hade varat kortare tid än fem år, kan bröstarvingen kräva att bodelning ändå görs, om bröstarvingen har rätt till det enligt lagen i den stat där den avlidne var medborgare. Bröstarvingen kan dock inte kräva det, om den stat som den avlidne sist hade hemvist $i$ är en stat som den andra maken var medborgare i vid den tidpunkt då äktenskapet ingicks. Om det i stället är så att det sista hemvistlandets lag inte ger den efterlevande maken rätt att sitta i oskiftat bo med bröstarvinge och hemvistet hade varat kortare tid än fem år, tillämpas lagen i det land där den avlidne var medborgare, om den lagen ger den efterlevande maken en sådan rätt (art. 3).

\subsubsection{Gällande rätt i länderna avseende efterlevande makes rättsställning}

Sedan konventionens tillkomst har betydande ändringar ägt rum i lagstiftningen i länderna vad gäller efterlevande makes rätt till den avlidne makens kvarlåtenskap. Den gällande rätten beskrivs kortfattat nedan.

\section{Danmark $^{7}$}

Om arvlåtaren var gift och efterlämnar inga bröstarvingar tillfaller kvarlåtenskapen den efterlevande maken. Vid den efterlevande makens död delas boet i utgångsläget mellan båda makarnas släktingar, så att vardera sidan får hälften av boet. 
Om däremot en gift arvlåtare efterlämnar bröstarvingar, ärver den efterlevande maken hälften av den avlidnes kvarlåtenskap. Den efterlevande maken får dock alltid ta ut så pass mycket egendom ur boet att den, tillsammans med den efterlevandes andel i bodelningen, hans eller hennes arvsandel samt enskilda egendom, motsvarar ett värde på 680000 Dkr (nivån år 2012). Den efterlevande makens rätt att behålla boet oskiftat i sin besittning är, om arvlåtaren efterlämnar särkullbarn, beroende av deras samtycke. Om de inte samtycker, kan den efterlevande maken behålla boet oskiftat i förhållande till de övriga arvingarna. Den efterlevande maken har rätt att när som helst begära skifte med en eller flera bröstarvingar. Boet ska alltid skiftas om den efterlevande maken ingår ett nytt äktenskap.

\section{Finland $^{8}$}

Om arvlåtaren var gift och efterlämnar inga bröstarvingar tillfaller kvarlåtenskapen den efterlevande maken. När den efterlevande maken dör, har vissa släktingar till den först avlidne maken rätt att få hälften av den efterlevande makens bo som efterarv.

Om däremot en gift arvlåtare efterlämnar bröstarvingar är utgångspunkten att den efterlevande maken får behålla den avlidnes kvarlåtenskap oskiftat i sin besittning endast om annat inte följer av en bröstarvinges krav på skifte eller av den avlidnes testamente. Oavsett bröstarvinges eller testamentstagares krav på skifte får emellertid den efterlevande maken behålla i sin besittning den bostad som använts som makarnas gemensamma hem, eller annan lämplig bostad som ingår i kvarlåtenskapen, om det inte i den efterlevande makens förmögenhet finns en som hem lämplig bostad. Sedvanligt bohag som finns i det gemensamma hemmet ska alltid lämnas oskiftat i den efterlevande makens besittning. Den efterlevande makens rätt till det gemensamma hemmet och det gemensamma bohaget påverkas inte av ett nytt äktenskap som han eller hon ingår.

\section{Island $^{9}$}

Om arvlåtaren var gift och efterlämnar inga bröstarvingar tillfaller kvarlåtenskapen den efterlevande maken. Vid den efterlevande makens död delas boet så att båda makarnas släktingar får hälften var av den kvarvarande egendomen.

Om däremot en gift arvlåtare efterlämnar bröstarvingar, ärver den efterlevande maken en tredjedel av den avlidnes kvarlåtenskap. Rätten att behålla boet oskiftat är beroende av bröstarvingarnas samtycke, utom när makarna hade ett testamente där de förordnat att den efterlevande

\footnotetext{
${ }^{8}$ De relevanta bestämmelserna återfinns i ärvdabalkens 3 kap. 1 -1a §§.

${ }^{9}$ De relevanta bestämmelserna återfinns i Erfðalögum nr. 8/1962, I. kafla.
} 
maken ska ha rätt att behålla boet oskiftat i sin besittning. Den efterlevande maken har rätt att när som helst begära skifte med en eller flera bröstarvingar. Boet ska alltid skiftas om den efterlevande maken ingår ett nytt äktenskap.

\section{Norge $^{10}$}

Om arvlåtaren var gift och efterlämnar inga bröstarvingar ärver den efterlevande maken hälften av kvarlåtenskapen, utan att efterarv aktualiseras. Om arvlåtaren efterlämnar bröstarvingar omfattar den efterlevande makens arvsrätt en fjärdedel av kvarlåtenskapen. Den efterlevande maken tillerkänns alltid rätt till ett s.k. minstearv, vars storlek beror på om den avlidne efterlämnar bröstarvingar eller inte. "Minstearvet" går före bröstarvingarnas rätt till laglott och kan inte sättas åt sidan genom testamente.

Den efterlevande maken har rätt att sitta i oskiftat bo. Om den avlidne maken efterlämnar särkullbarn måste dessa dock samtycka till "uskiftet". Om de inte samtycker, kan den efterlevande maken behålla boet oskiftat i förhållande till de övriga arvingarna. Boet ska alltid skiftas om den efterlevande maken ingår ett nytt äktenskap.

\section{Sverige $^{11}$}

Om arvlåtaren var gift tillfaller hela kvarlåtenskapen (såväl giftorättsgods som enskild egendom) enligt huvudregeln den efterlevande maken med fri förfoganderätt. Detta gäller både när den avlidne maken inte efterlämnar några bröstarvingar och när den avlidne efterlämnar bröstarvingar som är makarnas gemensamma. Andra bröstarvingar till den avlidne maken har däremot rätt att få ut sitt arv omgående vid arvlåtarens död, om de inte har avstått från sin arvsrätt till förmån för den efterlevande maken. Den efterlevande makens arvsrätt kan av arvlåtaren sättas åt sidan genom ett testamente.

Genom den s.k. basbeloppsregeln tillerkänns den efterlevande maken rätt att ur kvarlåtenskapen, så långt den räcker, alltid få egendom till ett så stort värde att den tillsammans med egendom som den efterlevande maken fick vid bodelningen eller som utgör den efterlevande makens enskilda egendom motsvarar fyra gånger det gällande basbeloppet. (År 2012 var basbeloppet $44900 \mathrm{Skr}$ )

Vid den efterlevande makens död delas kvarlåtenskapen mellan arvingarna efter vardera maken.

\footnotetext{
${ }^{10}$ De relevanta bestämmelserna om efterlevande makes arvsrätt finns i arveloven $\S \S$ 6-8 och bestämmelserna om efterlevande makes rätt till oskiftat bo i arveloven kapittel III.

11 De relevanta bestämmelserna finns primärt i 3 kap. $1 \S$ ärvdabalken.
} 


\subsection{Erkännande och verkställighet}

"I fråga om erkännande och verkställighet av dom eller förlikning om rätt att på grund av arv eller testamente, efterlevande makes rätt, boutredning eller skifte i anledning av dödsfall eller ansvarighet för den dödes gäld gäller lagen i den stat där erkännande eller verkställighet begäres." (Art. 28)

Vad gäller erkännande och verkställighet av domar som har meddelats eller förlikningar ingångna i en konventionsstat hänvisar art. 28 till lagen i den stat där erkännande eller verkställighet begärs. Denna bestämmelse kompletteras av art. 1 i 1977 års nordiska konvention om erkännande och verkställighet av domar på privaträttens område, ${ }^{12}$ enligt vilken såväl erkännande som verkställighet av en annan konventionsstats dom, annat avgörande och förlikning ska ske enligt lagen i den konventionsstat där erkännande och verkställighet söks. Den senare konventionen är en ramkonvention som har införlivats genom särskild lagstiftning i var och en av de fördragsslutande staterna med undantag av Island där 1932 års nordiska domskonvention fortfarande gäller. ${ }^{13}$ I Danmark, Finland, Norge och Sverige tillämpas 1977 års konvention på ärvande under förutsättning att det rör sig om ett avgörande eller en förlikning i ett nordiskt land och att den avlidne vid sin död både var medborgare i en nordisk stat och hade hemvist i någon av staterna. ${ }^{14}$ Tanken bakom konventionen har varit att avgöranden erkännas och verkställs på samma villkor som motsvarande inhemska avgöranden. Det krävs sålunda inte någon särskild prövning av huruvida ett i en nordisk stat meddelat avgörande gäller och kan verkställas i de övriga staterna.

\footnotetext{
12 Konventionen mellan Sverige, Danmark, Finland, Island och Norge om erkännande och verkställighet av domar på privaträttens område, Köpenhamn 11.10.1977.

13 Konventionen mellan Sverige, Danmark, Finland, Island och Norge om erkännande och verkställighetet av domar. Köpenhamn 16.3.1932.

${ }^{14}$ I Danmark gäller bekendtgörelse nr. 39 af 7 juni 1978 LTC, i Finland gäller lagen om erkännande och verkställighet av nordiska domar angående privaträttsliga anspråk (588/1977), i Norge tillämpas lov 10 juni $1977 \mathrm{nr} .71$ om anerkjennelse og fullbyrdelse av nordiske dommer på privatrettens område och i Sverige gäller lagen (1977:595) om erkännande och verkställighet av nordiska domar på privaträttens område.
} 



\section{Om allmänt tillämpliga internationellt privaträttsliga regler i de nordiska länderna - särskilt lagval}

Samtliga nordiska länder förutom Island omfattas av 1961 års Haagkonvention om tillämplig lag för testamentariska förordnanden. ${ }^{15}$ Lagvalsreglerna i denna konvention är universella, med vilket avses att de är tillämpliga oavsett om den utpekade lagen är en konventionsstats lag eller en annan stats lag. Härutöver gäller följande i de nordiska länderna.

\subsection{Danmark}

Dansk lagstiftning saknar regler om vilken stats lag som ska tillämpas på rätten till arv i de utomnordiska förhållandena. Enligt rättspraxis och doktrin tillämpas lagen i den stat där den avlidne hade hemvist (bopæl) vid sin död. Den tillämpliga lagen avser all den avlidnes egendom oavsett egendomens art och läge. Arvlåtaren torde inte ha rätt att förordna om vilken stats lag som gäller för rätten till arv.

\subsection{Finland}

Finland har sedan år 2002 allmänt tillämplig lagstiftning om internationella arvsfrågor i form av ett nytt 26 kapitel i ärvdabalken. Rätten till arv bestäms i första hand enligt den lag som arvlåtaren har bestämt ska gälla; flera alternativ gäller härvidlag. Om den avlidne inte har förordnat om annat bedöms rätten till arv enligt lagen i den stat där den avlidne hade hemvist vid sin död, om bosättningen där hade varat i minst fem år eller om den avlidne var medborgare där. Om ett sådant villkor inte är uppfyllt tillämpas lagen i den stat där arvlåtaren var medborgare, utom när det

15 Convention on the Conflicts of Laws Relating to the Form of Testamentary Dispositions, The Hague 5.10.1961. 
fanns väsentligt närmare anknytning till ett annat land. Den på arvet tillämpliga lagen omfattar all den avlidnes egendom.

\subsection{Island}

I Island finns inga lagfästa allmänt tillämpliga regler om rätten till arv. Enligt rättspraxis och doktrin tillämpas lagen i den stat där den avlidne hade hemvist vid sin död. Den tillämpliga lagen avser all den avlidnes egendom. Arvlåtaren torde inte ha rätt att förordna om tillämplig lag för rätten till arv.

\subsection{Norge}

Också Norge saknar allmänt tillämplig lagstiftning om internationella arvsfrågor. Enligt rättspraxis och doktrin styrs rätten till arv av lagen i den stat där den avlidne hade hemvist vid sin död. Denna lag omfattar all den avlidnes egendom. Arvlåtaren torde inte få bestämma vilken stats lag som ska gälla för rätten till arv.

\subsection{Sverige}

De allmänt tillämpliga reglerna om arv finns i lagen (1937:81) om internationella rättsförhållanden rörande arv. Lagen i den stat där den avlidne var medborgare vid sin död gäller för rätten till arv och omfattar i princip all den avlidnes egendom, oavsett egendomens art eller läge. Arvlåtaren har inte rätt att förordna om tillämplig lag för rätten till arv. År 1987 föreslog en utredning - familjelagssakkunniga - nya allmänt tillämpliga arvsregler för internationella förhållanden. Enligt förslaget skulle hemvistprincipen ersätta nationalitetsprincipen. Rätten till arv skulle enligt huvudregeln bedömas enligt lagen i den stat där den avlidne hade hemvist vid dödsfallet. Om emellertid den avlidne inte hade varit bosatt i den staten i minst två år skulle dock lagen i den stat tillämpas där han eller hon närmast förut hade haft hemvist, om det yrkas av en arvinge eller testamentstagare vars rätt beror därav. Arvlåtaren skulle vidare ha rätt att inom vissa gränser förordna om tillämplig lag för rätten till arv. Vidare föreslogs att den efterlevande makens rätt till arv alltid skulle bedömas enligt den lag som gäller vid bodelningen mellan den efterlevande maken och den avlidnes arvingar. Förslaget togs väl emot av remissinstanserna men har inte lett till lagstiftning. 


\section{Mot en moderniserad arvskonvention}

\subsection{Senare rättsutveckling och praktiska behov}

Den nordiska arvskonventionen kom till i syfte att underlätta flyttningen inom Norden genom enhetliga internationellt privaträttsliga regler om boutredning, arv och testamenten. Sedan dess, och inte minst efter tillkomsten av den gemensamma nordiska arbetsmarknaden år 1955, har rörligheten mellan länderna ökat markant. Det följer att den nordiska arvskonventionen är ett praktiskt relevant regelverk. Efter konventionens tillkomst har flera ändringar ägt rum inom ländernas materiella arvsrätt, andra närliggande områden och vad gäller allmänt tillämpliga internationellt privaträttsliga regler om arv och testamenten. Länderna såg år 2006 över de internordiska bestämmelserna avseende makars förmögenhetsförhållanden i 1931 års konvention. Enligt expertgruppens mening behöver även lagvalsregleringen i arvskonventionen ses över så att den står i samklang med den övriga rättsutvecklingen och bättre tillgodoser de behov som idag finns på det arvs- och testamentsrättsliga området vid flyttning inom Norden. För en översyn talar även att Finland och Sverige kommer att bli bundna av EU:s arvsförordning, när den börjar tillämpas. Det är angeläget att de internordiska reglerna står i samklang med arvsförordningen samtidigt som etablerade och välfungerande nordiska lösningar tas tillvara.

Enligt den nuvarande regleringen i arvskonventionen byts tillämplig lag på arv omedelbart vid byte av hemvist inom Norden. Resultaten i den rättsjämförande studie som initierades av de nordiska justitieministerierna i slutet av 1990-talet visar att det fortfarande finns betydande skillnader mellan de nordiska ländernas materiella regleringar, särskilt vad gäller efterlevande makes rätt till arv och vilka begränsningar som reglerna om laglott sätter för testationsfriheten, även om regelverken närmat sig varandra. ${ }^{16}$ Personer som flyttar mellan länderna kan ofta antas sakna kunskap om sådana skillnader. Resultatet kan också gå stick i stäv mot de efterlevandes förväntningar. I gällande rätt har de efterlevande, när döden inträffat, möjlighet att motverka effekten av bytet av

${ }^{16}$ Se Peter Lødrup, Nordisk arverett. En sammenlignende studie av dansk, finsk, islandsk, norsk og svensk rett med drøftelser av harmoniseringsmuligheter og reformbehov. Nord 2003:3. 
tillämplig lag och begära tillämpning av lagen i den avlidnes medborgarskapsstat, så länge som den avlidnes sista hemvist i det nya landet inte varat i minst fem år. Enligt expertgruppens förslag bör femårsregeln, vars tillämplighet styrs av de efterlevande, upphävas. I gengäld finns det anledning att överväga om inte bosättningen i det nya landet ska ha haft en viss varaktighet innan där gällande lag ska ersätta lagen i den tidigare hemviststaten.

Den nordiska expertgruppens första preferens var att föreslå samma lösning som nyligen antagits i den nordiska äktenskapskonventionen vad gäller byte av tillämplig lag för makars förmögenhetsförhållanden vid byte av hemvist inom Norden. För att tillämplig lag ska bytas ska makarnas bosättning i det nya landet ha varat i två år. ${ }^{17}$ På likadant sätt skulle en arvlåtares bosättning i en nordisk stat ha varat i minst två år för att där gällande lag ska vara tillämplig på arv och testamente. Utgången i förhandlingarna inom EU avseende Finlands och Sveriges rätt till undantag från arvsförordningen föranledde dock att expertgruppen fann anledning att ompröva sitt tidigare förslag. I och med att Finland och Sverige enligt villkoren i det beviljade undantaget är förpliktade att tillämpa arvsförordningens lagvalsregler, utom när annat kan följa av art. 75.3 punkten a gällande förfarandefrågor, beslutade expertgruppen att överge tvåårsregeln till förmån för den lösning som avses gälla enligt arvsförordningen. Enligt huvudregeln i arvsförordningen tillämpas lagen i den stat där arvlåtarens hemvist var vid dödstidpunkten. Undantagsvis medger arvsförordningen dock tillämpning av lagen i en annan stat till vilken arvlåtaren hade en uppenbart närmare anknytning, vilket t.ex. kan vara fallet när arvlåtaren relativt kort före dödsfallet flyttat till hemviststaten. ${ }^{18}$

Olikheterna mellan de nordiska ländernas regleringar och en allmän internationell utveckling i riktning mot att tillåta en arvlåtare att själv bestämma över tillämplig lag för rätten till arv efter honom eller henne (s.k. partsautonomi) har aktualiserat frågan om behovet att införa en motsvarande möjlighet i den nordiska arvskonventionen. Enligt den gällande lydelsen saknar arvlåtaren möjlighet att själv förordna om lagvalet. I stället åtnjuter arvingar och testamentstagare en rätt att disponera över den tillämpliga lagen, förutsatt att arvlåtarens hemvist i det nya landet inte varat i minst fem år. En sådan ordning, som lägger större vikt vid de efterlevandes än arvlåtarens egna önskemål, synes både opraktisk och otidsenlig och saknar motsvarighet i andra internationella instrument, EU:s arvsförordning inkluderad.

Enligt den nordiska äktenskapskonventionens år 2006 antagna nya lydelse har makar och blivande makar en rätt att inom vissa gränser av-

${ }^{17}$ Se konventionens art. 3a, såsom reviderad genom 2006 års ändringskonvention.

18 Se arvsförordningens artikel. 21 och därtill kopplade ingressatser. 
tala om tillämplig lag för förmögenhetsförhållandena i äktenskapet. ${ }^{19}$ Enligt expertgruppens mening är det angeläget att arvskonventionen ändras så att en arvlåtare som omfattas av konventionen ges rätt att inom vissa gränser förordna om tillämplig lag för rätten till arv efter honom eller henne. I gruppens ursprungliga förslag var lagvalsalternativen förenliga med dem som gäller enligt äktenskapskonventionen. Förslaget har senare justerats så att det även i detta hänseende motsvarar vad som tillåts enligt EU:s arvsförordning. Enligt arvsförordningen får en arvlåtare förordna att arvet ska bedömas enligt lagen i en stat där arvlåtaren vid tidpunkten för förordnandet eller vid sin död är medborgare.

\subsection{Relationen till EU:s arvsförordning}

Såsom framgått (avsnitt 1), lade EU-kommissionen fram ett förslag till Europaparlamentets och rådets förordning om behörighet, tillämplig lag, erkännande och verkställighet av domar och officiella handlingar i samband med arv och om inrättande av ett europeiskt arvsintyg sedan den nordiska expertgruppen i allt väsentligt slutfört sitt uppdrag år 2009. Både likheter och skillnader visade sig finnas mellan expertgruppens förslag och förordningsförslaget. En viktig likhet var att de båda förslagen lämnade utrymme för arvlåtarens lagvalsfrihet och, i avsaknad av ett lagvalsförordnande av arvlåtaren, lät hemvistprincipen styra över lagvalet. I enskildheter skilde sig förslagen dock åt. Vidare, medan expertgruppen inte hade funnit behov av att se över arvskonventionens regler avseende behörighet och erkännande och verkställighet, innehöll kommissionens förslag utförliga sådana regler liksom även förslag om införande av ett europeiskt arvsintyg. Expertgruppen gjorde initialt den bedömningen att dess eget förslag var enklare, mer flexibelt och bättre lämpat för de internordiska arvsförhållandena. Det inledda revideringsarbetet borde därför slutföras, förutsatt att det inte stötte på något hinder från EU:s sida.

På hösten 2011, när innehållet i EU:s arvsförordning i sak var i det närmaste klart, begärde Finland och Sverige ett undantag för att länderna emellan få tillämpa den nordiska arvskonventionen i en reviderad lydelse. Resultatet av dessa förhandlingar framgår av arvsförordningens art. 75.3. Enligt denna ska förordningen inte hindra att en reviderad nordisk arvskonvention ska få tillämpas av EU-medlemsstater som är parter till denna konvention (dvs. Finland och Sverige) i den mån som konventionen innehåller (a) "regler avseende förvaltningen av dödsboet såsom anges i konventionen och medverkan av myndigheter i de fördrags-

${ }^{19}$ Se konventionens art. 3, såsom reviderad genom 2006 års ändringskonvention. 
slutande staterna", och (b) "enklare och snabbare förfaranden för erkännande och verkställighet av domar i samband med arv". En förutsättning för att detta undantag ska gälla är dock att en reviderad version av den nordiska arvskonventionen har antagits innan EU:s arvsförordning antas.

Det beviljade undantaget är inte bara bundet i tid, utan klart mindre generöst än vad länderna hade begärt. Mest slående är att det inte omfattar de artiklar avseende tillämplig lag för kvarlåtenskapens överföring som stått i förgrunden för det nordiska revideringsarbetet. De regler i den reviderade arvskonventionen som Finland och Sverige enligt art. 75.3 får tillämpa är, som framgått, begränsade till regler för förfarandeaspekter avseende dödsboförvaltning och enklare och snabbare förfaranden för erkännande och verkställighet av domar. I båda hänseendena innebär förslaget till revideringskonventionen inte någon ändring i sak i förhållande till vad som gäller enligt arvskonventionens nuvarande lydelse.

Den nordiska expertgruppen har i det uppkomna läget mötts på nytt för att analysera tillgängliga handlingsalternativ. Fyra sådana har identifierats.

Ett alternativ går ut på att avbryta det nordiska revideringsarbetet, utan att någon ändring i arvskonventionen genomförs. För detta alternativ talar främst den enorma tidspress som länderna utsatts för i och med att en revideringskonvention måste vara antagen innan arvsförordningen antas inom EU.

Ett annat alternativ innebär att länderna fortsätter med revideringsarbetet, i enlighet med expertgruppens förslag från 2009. Arbetet med en revidering av den nordiska arvskonventionen har haft ett starkt politiskt stöd i länderna. Konventionen har fungerat bra i rättstillämpningen och är tämligen enkel att tillämpa. De år 2009 föreslagna lagvalsreglerna innebär en viktig modernisering av konventionen och återspeglar de lösningar som länderna för något år sedan kom överens om avseende makars förmögenhetsförhållanden. Dessa senare lösningar har också genomförts i samtliga länder.

Ett tredje alternativ är att det ursprungliga förslaget till revideringskonventionen från 2009 justeras så att de mest grundläggande lagvalsreglerna avseende materiella testaments- och arvsfrågor blir i linje med arvsförordningens motsvarande bestämmelser. En fördel med denna lösning är att lagvalet i viktiga hänseenden inte kommer att skilja sig åt vare sig det görs i de av arvsförordningen bundna EUmedlemsstaterna Sverige eller Finland eller i de nordiska länderna som står utanför EU-samarbetet, nämligen Island och Norge och i förekommande fall även Danmark. ${ }^{20}$ En viss och behövlig modernisering av konventionen kan sålunda uppnås. En annan fördel är att de enkla och välfungerande nordiska bestämmelserna om erkännande och verkställighet

20 Som bekant, har Danmark av EU beviljats ett undantag för att inte delta i EU:s s.k. civilrättsliga samarbete, alltså den typ av frågor som bland annat arvsförordningen handlar om. 
fortsätter att vara tillämpliga de nordiska länderna emellan, liksom bestämmelserna avseende administrativa förfaranden kring en kvarlåtenskaps överföring. Däremot kommer Finland och Sverige att vara bundna av arvsförordningens regler om jurisdiktion, och av alla de övriga bestämmelser som inte omfattas av det beviljade undantaget. Enligt expertgruppens analyser behöver dock detta inte medföra några större praktiska olägenheter i de internordiska relationerna.

Ytterligare ett alternativ som diskuterats har varit utsikterna att på sikt kunna få till stånd ett avtal mellan EU, å ena sidan, och Danmark, Island och Norge, å andra sidan, om en överenskommelse om väsentligen likartade regler som i arvsförordningen. Det är dock oklart hur realistiskt och genomförbart detta alternativ är. Arvsförordningens invecklade struktur och innehåll gör även att den kanske inte heller framstår som attraktiv för de länder som inte har deltagit i förhandlingarna.

Expertgruppen har efter överläggningar valt att förespråka det tredje alternativet. Den stora fördelen med denna lösning är att internordiska arv fortsätter att styras av likartade regler. En nödvän dig modernisering avseende valet av tillämplig lag kan uppnås, samtidigt som konventionens enkla förfarande-, erkännande- och verkställighetsmekanismer kan behållas oförändrade.

\subsection{Vilka situationer avses omfattas av de reviderade nordiska reglerna?}

\subsubsection{En fortsatt stark internordisk anknytning genom både hemvist och medborgarskap}

En första fråga som expertgruppen hade att ta ställning till var vilka situationer som de nya reglerna bör omfatta. I sin nuvarande lydelse förutsätter arvskonventionens tillämplighet, med något undantag, att den avlidne vid sin död var medborgare i en fördragsslutande stat och då hade hemvist i en annan fördragsslutande stat. Det förutsätts med andra ord enligt huvudregeln att anknytning finns till två olika nordiska länder, genom arvlåtarens medborgarskap och arvlåtarens hemvist. Genom att konventionen beaktar dessa anknytningsmoment endast vid dödstidpunkten, spelar det idag ingen roll om den avlidne tidigare varit medborgare i en icke fördragsslutande stat eller tidigare haft hemvist $\mathrm{i}$ en sådan stat. Konventionens regler kan endast medföra tillämpning av de fördragsslutande staternas lagar.

Enligt expertgruppens mening är det en naturlig utgångspunkt att de internordiska reglerna även framöver avser fall där den avlidne vid sin bortgång både var nordisk medborgare och hade hemvist i en annan nordisk stat. Sådana regler har visat sig fylla ett praktiskt behov. 
Liksom hittills bör alltså konventionen även framöver primärt avse situationer där den döde vid sin bortgång var nordisk medborgare men hade hemvist i en annan nordisk stat. I några fall skulle det dock föra för långt att hålla fast vid kravet på en sådan anknytningskombination. Om sålunda en nordisk medborgare har förordnat att en fördragsslutande stats lag ska tillämpas på rätten till arv efter honom eller henne, bör lagvalsförordnandets giltighet kunna prövas enligt konventionen även om arvlåtaren vid sin död hade hemvist i den stat där han eller hon också var medborgare och situationen följaktligen vid dödstillfället framstår som "intern". Det är i praktiken inte ovanligt att en nordisk medborgare, som länge haft hemvist i en annan nordisk stat, senare återvänder till den stat vari han eller hon är medborgare. I ett sådant fall talar såväl praktiska skäl som önskan om förutsebarhet för att situationen fortsätter att omfattas av konventionen. Det kan även hända att konventionens behörighetsregler, som föreslås bli oförändrade, kan omfatta situationer som vid tidpunkten för dödsfallet framstår som "interna".

Expertgruppen har övervägt huruvida det finns behov av en viss skärpning av konventionens tillämpningskriterier. Det har särskilt diskuterats huruvida konventionens bestämmelser borde vara tillämpliga endast under förutsättning att den avlidnes sista bosättning inom de fördragsslutande staterna vid dödstidpunkten hade varat i minst två år. Så blev också innehållet i expertgruppens ursprungliga förslag. I och med utgången i förhandlingarna inom EU avseende räckvidden av ett nordiskt undantag och expertgruppens preferens för det ovan identifierade tredje alternativet har en sådan skärpning, som saknar egentligt motstycke i arvsförordningens lagvalsregler, inte längre varit aktuell.

\subsubsection{Endast en fördragsslutande stats lag kan bli tillämplig}

Enligt expertgruppens mening bör utgångspunkten vara att den nordiska arvskonventionen även framöver endast kan leda till tillämpning av en annan fördragsslutande stats lag. ${ }^{21}$ Detta ska gälla i såväl de fall där arvlåtaren själv har förordnat om tillämplig lag som de fall där tilllämplig lag fastställs utan sådant förordnande.

En fördel med denna lösning är att den inskränker konventionens tilllämplighet till situationer som har starka nordiska anknytningar. Konventionens ursprungliga syfte att underlätta flyttning inom de nordiska länderna fortsätter därmed att vara giltigt. Lösningen har även den fördelen att konventionsregleringen kan hållas relativt enkel, genom att det till exempel inte finns behov av någon bestämmelse om ordre public. Även

\footnotetext{
${ }^{21}$ Ett undantag sedan översynen år 1975 är konventionens art. 8 som även kan medföra tillämpning av en icke fördragsslutande stats lag. Artikeln har utformats med utgångspunkt i 1961 års Haagkonvention om tillämplig lag för formen för testamentariska förordnanden. I sak föreslås inga förändringar till denna artikel.
} 
om det finns skillnader mellan de fördragsslutande staternas regleringar på det arvs- och testamentsrättsliga området, är dessa skillnader inte av sådan karaktär att de motiverar en särskild bestämmelse om ordre public. En annan bedömning vore sannolikt påkallad om konventionen även kunde medföra tillämpning av en icke fördragsslutande stats lag.

\subsection{Vilken stats lag ska bestämma över arvet när arvlåtaren inte har förordnat om annat?}

\subsubsection{Arvskonventionens nuvarande lydelse och jämförelser}

Enligt den gällande lydelsen av arvskonventionen byts tillämplig lag för rätten till arv omgående när en nordisk medborgare tar hemvist i ett annat nordiskt land, men med de inskränkningar som följer av en s.k. femårsregel till skydd för arvingar och testamentstagare. Tillämpning av hemvistprincipen gäller alltså som utgångspunkt, men kan på begäran av arvinge eller testamentstagare åsidosättas till förmån för tillämpning av medborgarskapsstatens lag så länge som arvlåtarens sista hemvist i det nya landet inte varat i minst fem år. Konventionen ger inte arvlåtaren själv någon möjlighet att förordna om tillämplig lag för arv och testamente.

För femårsregeln talade vid konventionens utarbetande de stora skillnaderna mellan ländernas lagar, särskilt i fråga om legal arvsrätt och efterlevande makes rätt till oskiftat dödsbo. Lösningen motiverades i förarbetena med hänsyn till såväl arvlåtaren själv - arvlåtaren antogs behöva viss tid för att anpassa sig till traditionerna i det nya landet och bli förtrogen med där gällande arvslag bland annat för att kunna bedöma behovet av att upprätta testamente - som arvingarnas berättigade förväntningar. ${ }^{22}$ Fråga var vidare om en kompromiss mellan hemvistprincipen och nationalitetsprincipen. Det bör noteras att det alltså inte är arvlåtaren som bestämmer vilken stats lag som ska tillämpas när hemvistet inte varat $\mathrm{i}$ fem år, utan i stället arvingar och testamentstagare.

Den nuvarande lösningen kan jämföras med Finlands allmänna regler för ärvande. Om arvlåtaren inte har förordnat om annat tillämpas i första hand lagen i den stat där arvlåtaren vid sin död hade hemvist. Om emellertid arvlåtaren tidigare haft hemvist i en annan stat, tillämpas lagen i den sista hemviststaten endast om arvlåtaren vid sin död var medborgare där eller hade varit bosatt där i minst fem år omedelbart före sin död. I sista hand tillämpas lagen i det land arvlåtaren var medborgare i. Reglerna lämnar i det fallet ett visst utrymme för tillämpningen av lagen i en stat till

22 NJA II 1935 s. 358 f. 
vilken arvlåtaren med beaktande av alla omständigheter hade en väsentligt närmare anknytning än till medborgarskapsstaten.

Den finska lösningen är influerad av 1989 års Haagkonvention om tillämplig lag för rätten till avlidna personers kvarlåtenskap. Enligt konventionens artikel 3 gäller följande:" (1) Succession is governed by the law of the State in which the deceased at the time of his death was habitually resident, if he then was a national of that State. (2) Succession is also governed by the law of the State in which the deceased at the time of his death was habitually resident if he had been resident there for a period of no less than five years immediately preceding his death. However, in exceptional circumstances, if at the time of his death he was manifestly more closely connected with the State of which he then was a national, the law of that State applies."

Det svenska förslaget av familjelagssakkunniga från år 1987 är däremot mer i linje med den nuvarande huvudregeln i den nordiska arvskonventionen. Rätten till arv bedöms enligt lagen i den stat där den avlidne hade hemvist vid sin död. Denna lag kan dock åsidosättas till förmån för tillämpning av lagen i den närmast förutvarande hemviststaten, på begäran av en intresserad arvinge eller testamentstagare, under förutsättning att arvlåtarens bosättning i det senaste hemvistlandet inte varat i minst två år. Ett ytterligare villkor för att en sådan begäran får framställas är att arvlåtaren vid sin död inte var medborgare i den sista hemviststaten eller tidigare haft hemvist där.

\subsection{2 Ändringsbehov}

Expertgruppen har ställt sig följande frågor. Är ett omgående byte av tilllämplig lag som huvudregel fortfarande motiverat när en nordisk medborgare byter hemvist inom Norden? Är det rimligt att kräva fem års hemvist i det nya landet för att där gällande lag inte på begäran av arvinge eller testamentstagare ska kunna ersättas av lagen i medborgarskapsstaten?

Expertgruppen har kommit fram till att i båda hänseendena är en ändring påkallad. Gruppens ursprungliga preferens var att följa den modell som länderna antagit vad gäller byte av tillämplig lag för makars förmögenhetsförhållanden när nordiska makar byter hemvist inom Norden utan att ha avtalat om annat. Detta skulle ha inneburit att vid flyttning från en fördragsslutande stat till en annan byts tillämplig lag enligt huvudregeln till den nya hemviststatens lag först när bosättningen i det nya landet varat i två år. Tillämplig lag skulle dock bytas omgående till lagen i den nya hemviststaten om den avlidne tidigare haft hemvist i den staten.

Expertgruppen noterade att kravet på en två års bosättning kunde i internationell jämförelse framstå som en kort period, men fann det väl lämpat i de internordiska situationerna med hänsyn till att olikheterna mellan lagarna i Norden är begränsade. Enligt expertgruppens ursprungliga förslag skulle således, i händelse av hemvistbyte, den senaste 
bosättningen ha haft en viss varaktighet - två år - för att där gällande lag ska bli tillämplig, eller att arvlåtaren tidigare haft hemvist i den staten. Om dessa rekvisit inte var uppfyllda skulle enligt förslaget lagen i den fördragsslutande stat gälla där arvlåtaren närmast förut hade hemvist. Om även den bosättningen hade varat kortare tid än två år, skulle tilllämplig lag bestämmas med beaktande av till vilken fördragsslutande stat den avlidne, med hänsyn tagen till samtliga omständigheter, hade starkast anknytning. Förslaget var inspirerat av både den finska lagen och Haagkonventionen, men även av det svenska förslaget från 1987. Dessa modeller tillmäter, fastän på olika sätt, arvlåtarens medborgarskap och tidigare hemvist betydelse.

Efter utgången i förhandlingarna inom EU har detta förslag modifierats så att det motsvarar vad som följer av arvsförordningen. Det uttryckliga kravet på två års bosättning i det nya landet har således utgått, liksom de övriga speciella nyanserna i det ursprungliga förslaget. En nackdel med detta är att den tydlighet och förutsebarhet som en tvåårsregel kan förväntas föra med sig går förlorade. Samtidigt är det svårt att se att skillnaderna skulle ha några större praktiska konsekvenser. Särskilt som den undantagsregel som i stället införs efter förebild i arvsförordningen medger ett visst, om än begränsat, utrymme för att beakta bl.a. den omständigheten att arvlåtaren tämligen kort tid före dödsfallet fătt hemvist i en annan fördragsslutande stat. Att de nordiska länderna även framöver kan tillämpa likartade regler på ärvande framstår däremot som en definitiv fördel, varför expertgruppen har valt att föreslå en justering i enlighet med arvsförordningen.

\subsection{Arvlåtarens rätt att bestämma tillämplig lag}

\subsubsection{Arvskonventionens nuvarande lydelse och jämförelser}

Iögonenfallande är att den gällande ordningen i den nordiska arvskonventionen inte tillåter arvlåtaren själv att bestämma över tillämplig lag. Valmöjligheten tillkommer i stället arvingar och testamentstagare.

Under senare årtionden har det i en del länder, däribland Finland, förekommit en utveckling i riktning mot att tillåta arvlåtaren att inom vissa gränser bestämma vilken lag som ska tillämpas i fråga om arvet. Enligt de finska reglerna får arvlåtaren som tillämplig lag förordna lagen i den stat i vilken arvlåtaren är medborgare när förordnandet ges eller vid sin död, eller lagen i den stat där arvlåtaren har hemvist när förordnandet ges eller vid sin död eller där han eller hon tidigare har haft hemvist. En gift arvlåtare får därutöver förordna som tillämplig lag lagen i den stat som gäller för förmögenhetsförhålland ena i äktenskapet.

Även i den år 1989 i Haag antagna konventionen finns en sådan rätt föreskriven (art. 5). Arvlåtarens förordnande är verksamt under förutsätt- 
ning att det avser lagen i ett land där arvlåtaren vid tidpunkten för förordnandet eller sin död var medborgare eller hade hemvist. Någon särskild regel avseende en gift arvlåtares valmöjligheter finns inte i konventionen.

Enligt det svenska förslaget från 1987 skulle arvlåtarens lagvalsförordnande vara verksamt om det avser tillämpning av lagen i en stat där arvlåtaren vid förordnandet eller sin död hade hemvist eller var medborgare eller där han eller hon tidigare hade haft hemvist.

\subsection{2 Ändringsbehov}

Ett argument för att tillåta arvlåtaren att bestämma över tillämplig lag är att arvlåtaren har en rätt att genom testamente i sak förordna om sin kvarlåtenskap. Enligt gällande rätt kan skillnaderna mellan de nordiska länderna vad avser testationsfriheten och laglottsskyddets omfattning medföra att ett testamente, som var giltigt till sitt innehåll när det upprättades i en nordisk stat enligt där gällande regler, inte kan genomföras ifall arvlåtaren vid sin död hade haft hemvist i minst fem år i en annan nordisk stat. Genom att förordna om tillämplig lag kan arvlåtaren, ifall lagvalsfriheten godtas, skapa förutsebarhet om vilken stats lag som kommer att gälla. Vidare: Om det är möjligt att välja tillämplig lag, underlättas kvarlåtenskapsplaneringen och arvlåtarens möjligheter att nå det sakliga resultat som han eller hon eftersträvar.

Ytterligare ett argument som talar för att tillåta att arvlåtaren får förordna om tillämplig lag för kvarlåtenskapens överföring är att makarna enligt den nyligen reviderade nordiska äktenskapskonventionen får avtala om tillämplig lag för förmögenhetsförhållandena i äktenskapet. Om arvlåtaren är gift och makarna gemensamt avtalar om tillämplig lag i fråga om förmögenhetsförhållandena i äktenskapet, kan det finnas ett praktiskt behov av att också förordna om tillämplig lag beträffande arvet, om möjligt på så sätt att samma stats lag gäller för båda frågorna.

Arvlåtarens intresse av att själv kunna planera för arvet ska dock bl.a. vägas mot de lagskyddade krav på andel i kvarlåtenskapen som efterlevande make och bröstarvingar kan ha. Med tanke på att arvlåtaren inte helt kan förbigå sådana anspråk genom ett förordnande i testamente, kan det finnas anledning att begränsa rätten att välja lag. Detta skäl har varit avgörande för varför arvlåtarens lagvalsfrihet, när sådan godtas, regelmässigt är begränsad till rättsordningar till vilka arvlåtaren har en naturlig nära anknytning. Likadana begränsningar gäller makars frihet att avtala om tillämplig lag för egendomsordningen i äktenskapet.

Expertgruppen har funnit att det finns skäl att arvskonventionen framöver ger varje arvlåtare, som omfattas av konventionen, rätt att förordna om tillämplig lag för arv och testamente. Ett sådant förordnande föreslås ske i form av testamente. Med introduktionen i den nordiska arvskonventionen av en möjlighet till lagval för arvlåtaren ökar möjligheterna till kvarlåtenskapsplanering för arvlåtaren, liksom förutsebarheten om vilken stats lag 
som kommer att vara tillämplig. En konsekvens av detta blir att det inte finns anledning att ha kvar en femårsregel.

Expertgruppens ursprungliga förslag gick ut på att begränsa arvlåtarens lagvalsmöjligheter på ett sätt som liknar de tidigare nämnda regelverken. De anknytningar som skulle berättiga till att arvlåtaren väljer en viss fördragsslutande stats lag som tillämplig skulle enligt det ursprungliga förslaget vara arvlåtarens hemvist eller medborgarskap, vid tidpunkten för förordnandet eller vid dödsfallet. Med den finska lagen och den reviderade äktenskapskonventionen som förebilder föreslog expertgruppen från början även att arvlåtaren skulle kunna förordna om tillämpning av lagen i en fördragsslutande stat där han eller hon tidigare haft hemvist. En sådan lösning ansågs ge en något större flexibilitet vid arvlåtarens kvarlåtenskapsplanering. Det är kanske först efter hemvistbytet som arvlåtaren inser fördelarna med att det tidigare hemvistlandets lag får bestämma över kvarlåtenskapen. Expertgruppen föreslog även, i enlighet med den finska lagen, att en gift arvlåtare skulle få förordna att arvet ska bedömas enligt samma stats lag som gäller för makarnas förmögenhetsförhållanden.

Efter utgången i förhandlingarna inom EU har detta förslag justerats så att det motsvarar vad som följer av arvsförordningen. Jämfört med expertgruppens ursprungliga förslag är det fråga om en betydligt snävare partsautonomi, som inte motsvarar de många valmöjligheter som gäller för makars förmögenhetsförhållanden enligt 2006 års nordiska revideringskonvention. Detta är ett bakslag. Fördelen är dock att denna utformning för förslaget blir i linje med lagvalsfriheten i EU:s arvsförordning. För de nordiska medborgarna kan en enhetlig bedömning av lagvalet ha ett värde i sig. Olika regler beroende på situationens anknytning kan skapa förvirring. En begränsad partsautonomi för arvlåtaren är vidare en bättre lösning än dagens reglering som inte ger arvlåtaren någon möjlighet till lagval.

Eftersom konventionen avses även framöver bara kunna avse tilllämpning av en annan fördragsslutande stats lag uppstår frågan vad som ska gälla när en arvlåtare, som genom sina senaste hemvist- och medborgarskapsanknytningar omfattas av konventionen, har förordnat om tillämpning av en icke fördragsslutande stats lag. Praktiska skäl talar enligt expertgruppens mening för att lagvalsförordnandets giltighet i ett sådant fall prövas i varje fördragsslutande stat enligt där gällande allmänt tillämpliga regler. 


\subsection{Efterlevande makes rättsställning - finns det behov att samordna tillämplig lag för arv med tillämplig lag för makars förmögenhetsförhållanden?}

Den efterlevande makens rättsställning regleras särskilt i flera artiklar i den gällande konventionstexten. Flera av reglerna har berörts ovan i avsnitt 4.3. En utgångspunkt synes vara att den efterlevande maken bör komma i åtnjutande av de regler i den avlidnes sista hemvistland som har till syfte att tillgodose skyddet av den efterlevande maken.

Konventionens bestämmelser om efterlevande makes rätt till oskifte (ovan avsnitt 4.3) bygger på ett rättsläge i de olika länderna som delvis är ett annat än det som råder i dag. Regleringen är detaljerad, invecklad och delvis svårtillämpad. Enligt expertgruppens bedömning lär regleringen väsentligen ha spelat ut sin roll i och med den rättsutveckling som skett i de fördragsslutande staterna sedan konventionen kom till. Därför föreslås de aktuella bestämmelserna bli upphävda i konventionen. Frågan uppstår om konventionen i stället borde omfatta någon annan särlösning för de fall där den avlidne var gift vid sin bortgång.

Allmänt kan sägas att om den avlidne var gift och ett lands lag tilllämpas vid bodelningen, i de fall en bodelning görs, varefter ett annat lands lag tillämpas vid arvskiftet, finns det en risk för resultat som inte tillgodoser den efterlevande makens intresse på ett skäligt sätt. Tyngdpunkten i skyddet av efterlevande make ligger nämligen inte alltid i samma delar av regelsystemen och effekten kan bli att efterlevande make blir överkompenserad eller underkompenserad vid en kombination av dem.

Frågan om behovet av och metoderna för att uppnå samordning mellan den lag som tillämpas på förmögenhetsförhållandena i äktenskapet och den lag som gäller för arvet har diskuterats ingående inom expertgruppen. Som jämförelse kan nämnas de svenska familjelagssakkunnigas förslag från 1987 enligt vilket den lag som gäller vid bodelning mellan den efterlevande maken och den avlidne makens arvingar även skulle gälla för den längstlevande makens rätt att ta arv efter den avlidne maken.

Även om en samordning i sig kan vara önskvärd finns det enligt expertgruppens mening inte behov av en särskild regel i detta syfte. Trots vissa skillnader mellan de nordiska rättsordningarnas sätt att skydda en efterlevande make nås en tillräcklig skyddsnivå oavsett vilken eller vilka av lagarna som tillämpas i de olika delarna. Ytterligare ett argument mot en sådan särlösning är att det skulle innebära en betydande inskränkning av arvlåtarens frihet att få förordna om tilllämplig lag. Arvlåtarens förordnande avseende tillämpning av en an- 
nan stats lag skulle i så fall behöva lämnas utan avseende vad gäller den efterlevande makens rättsställning.

I och med att inte heller EU:s arvsförordning innehåller någon särskild lagvalsregel avseende efterlevande makes rättigheter har expertgruppens slutsatser inte behövt omprövas i denna del.

\subsection{Hur förhåller sig konventionen och förslaget till personer av samma kön som har ingått äktenskap, registrerade partner och samboende personer?}

Enligt konventionens regler gör en persons civilrättsliga status ingen skillnad. Den lag som ska tillämpas enligt förslagets artikel 2 eller artikel 3 gäller sålunda oavsett om den avlidne var gift, registrerad partner, samboende eller ensamstående.

Enligt norsk, svensk och isländsk rätt kan två män, två kvinnor eller en man och en kvinna ingå äktenskap med varandra. I dessa tre länder är alltså äktenskapsbegreppet numera könsneutralt. Från och med den 15 juni 2012 kommer äktenskap att kunna ingås mellan två män eller två kvinnor även i Danmark. I Finland gäller att äktenskap kan ingås bara mellan en man och en kvinna.

Det förefaller givet att varje fördragsslutande stat vid bedömning av denna fråga använder sin egen begreppsbildning vid konventionens tilllämpning. Det följer att i Island, Norge, Sverige och Danmark betraktas samkönade makar som gifta medan så inte förväntas bli fallet i Finland under en överskådlig framtid. Frågan förefaller ha begränsad betydelse mot bakgrund av att expertgruppens förslag, i likhet med arvsförordningen, inte innehåller någon särskild lagvalsregel avsedd för gifta arvlåtare.

En annan fråga är hur konventionen förhåller sig till personer som är samboende utan att ha ingått äktenskap med varandra eller registrerat partnerskap. Till saken hör att gällande svensk rätt skyddar sambor genom regler om bodelning vid samboförhållandets upplösning. ${ }^{23}$ Sveriges allmänt tillämpliga internationellt privaträttsliga regler om makars förmögenhetsförhållanden omfattar även sambors förmögenhetsförhållanden. ${ }^{24}$ Norge har för ett par år sedan infört arvsrätt för sambor. ${ }^{25} \mathrm{I}$ Danmark saknar en ogift sambo arvsrätt, utom när det följer av den avlidne sambons testamente. Ogifta sambor kan genom att upprätta ett s.k. "samlevertestamente" åstadkomma samma skydd som enligt lagen gäller för makar. ${ }^{26}$ Finland införde år 2010 en särskild lag om rättsförhål-

\footnotetext{
23 Sambolagen (2003:376), särskilt 8 §.

24 Se lagen (1990:272) om internationella frågor rörande makars och sambors förmögenhetsförhållanden.

25 Se lov 3 mars 1972 nr. 5 om arv m.m., kapittel III A.

${ }^{26}$ Se Arvelovens 87-89 §§.
} 
landen mellan sambor, dock utan bestämmelser om arvsrätt mellan sambor. ${ }^{27}$ Enligt expertgruppens bedömning bör det vara tillräckligt med den lagvalsfrihet som föreslås gälla för en arvlåtare.

\section{8 Övriga ändringar}

Eftersom konventionens bestämmelser är anpassade till den arvsrättsliga reglering som gällde i de nordiska länderna när konventionen utarbetades, kan vissa av dess övriga bestämmelser framstå som föråldrade eller i vart fall svårtolkade för den nutida läsaren. Expertgruppen har därför valt att föreslå vissa språkliga ändringar utan att någon saklig ändring är avsedd. Målsättningen med denna revidering har dock varit minimalistisk, såtillvida att endast praktiskt påkallade ändringar förespråkas.

${ }^{27}$ Se lagen om upplösning av sambors gemensamma hushåll (26/2011). 


\section{De föreslagna ändringarna jämte motivering}

\section{1 Ändrad rubrik för Avdelning I}

Föreslagen lydelse: - "I. Arv och testamente"

Enligt den gällande lydelsen nämns, förutom arv och testamente, även oskiftat bo i rubriken för Avdelning I. Eftersom den efterlevande makens rätt till oskiftat bo inte längre föreslås omfattas av särskilda regler, har rubriken förkortats på motsvarande sätt. Konventionen fortsätter dock enligt förslaget att omfatta rätten till oskiftat bo, som utgör en del av arvsrättsproblematiken i de aktuella länderna.

\subsection{Artikel 1}

Föreslagen lydelse:

"Bestämmelserna i denna konvention tillämpas på frågor om arv och testamente efter en person som vid sin död var medborgare och hade hemvist $i$ en fördragsslutande stat, utom när annat följer av Europaparlamentets och rådets förordning (EU nr --) om behörighet, tillämplig lag, erkännande och verkställighet av domar samt godkännande och verkställighet av officiella handlingar i samband med arv och om inrättandet av ett europeiskt arvsintyg."

\section{Kommentar}

Utgångspunkten är att konventionens regler om arv och testamente även framöver ska gälla efter den som vid sin död är medborgare i en fördragsslutande stat och som då har hemvist i någon av de andra fördragsslutande staterna. Övervägandena bakom detta ställningstagande har redovisats ovan under avsnitt 6.3.

Annat kan dock följa av EU:s arvsförordning med följden att arvsförordningens bestämmelser måste ges företräde. Denna begränsning är av relevans för Finland och Sverige vilka är de enda nordiska länderna som kommer att omfattas av arvsförordningen. För de övriga länderna, som inte är bundna av arvsförordningens bestämmelser, saknar den omedelbar betydelse. Begränsningen följer av Sveriges och 
Finlands skyldigheter att ge arvsförordningen företräde, utom när annat följer av förordningens art. 75.3.

\subsection{Artikel 2}

Föreslagen lydelse

"När arvlåtaren inte har bestämt annat $i$ enlighet med vad som sägs $i$ artikel 3, tillämpas i fråga om rätt till arv efter honom eller henne lagen i den fördragsslutande stat där han eller hon vid sin död hade hemvist.

Om det undantagsvis framgår av samtliga omständigheter i fallet att den avlidne vid sin död uppenbart hade en närmare anknytning till en annan fördragsslutande stat än den vars lag skulle vara tillämplig enligt stycke 1, ska lagen i den andra staten tillämpas i fråga om rätt till arv. ”

\section{Kommentar}

Det följer av artikelns första stycke att enligt huvudregeln, utom när den döde har förordnat om annat enligt artikel 3, följer rätten till arv eller testamente lagen i den fördragsslutande stat där den avlidne hade hemvist vid sin bortgång.

Det uppnås en viss flexibilitet och tillfälle att beakta omständigheterna i det enskilda fallet genom att artikelns andra stycke öppnar för en möjlighet att tillämpa en annan fördragsslutande stats lag. En förutsättning är att det vid en samlad bedömning av samtliga omständigheter står klart att den avlidne vid tidpunkten för sin död hade närmare anknytning till den andra staten. Ett exempel när undantagsregeln kan bli tillämplig är när arvlåtaren tämligen kort tid före dödsfallet flyttat till en fördragsslutande stat och fătt hemvist där men övriga omständigheter starkt pekar i riktning mot en annan fördragsslutande stat. Bestämmelsen är avsedd att tolkas restriktivt, vilket markeras av kravet att en sådan avvikelse bara "undantagsvis" kan komma i fråga när den avlidne "uppenbart" hade närmare anknytning till den andra staten.

Den föreslagna lydelsen motsvarar väsentligen art. 21 i EU:s arvsförordning, ${ }^{28}$ men hänvisar av i sammanhanget givna skäl endast till en annan fördragsslutande stats lag. Den föreslagna lydelsen tar till vara även de möjligheter som öppnats genom det till Finland och Sverige beviljade undantaget i arvsförordningens art. 75.3 punkten a. Av denna

\footnotetext{
${ }^{28}$ Artikel 21 i arvsförordningen har följande lydelse.

1. Om inte annat anges $i$ denna förordning ska den lag som är tillämplig på arvet $i$ dess helhet vara lagen $i$ den stat där den avlidne hade hemvist vid sin död.

2. Om det undantagsvis framgår av alla omständigheter i fallet att den avlidne vid sin död uppenbart hade en närmare anknytning till en annan stat än den vars lag skulle vara tillämplig enligt punkt 1 , ska lagen $i$ den andra staten vara tillämplig på arvet.
} 
punkt följer att i de internordiska fallen är det tillåtet att följa de administrativa föreskrifter rörande dödsboförvaltningen som gäller enligt konventionen. För att få fram denna aspekt hänvisas det, i motsats till arvsförordningen, inte till "arv i dess helhet". Denna aspekt är av relevans även för Finland och Sverige vilka, utom när art. 75.3 föreskriver annat, är bundna av arvsförordningens bestämmelser.

Jämfört med den gällande lydelsen av arvskonventionen innebär förslaget att möjligheten för arvinge och testamentstagare att begära tilllämpning av lagen i den fördragsslutande stat där den avlidne var medborgare tas bort. Denna möjlighet har gällt om hemvistet i en annan fördragsslutande stat hade varat kortare tid än fem år. I gengäld föreslås det i art. 3 att arvlåtaren själv ska kunna bestämma över tillämplig lag. I och med att arvlåtaren får en sådan beslutanderätt är det naturligt att resultatet i avsaknad av sådant förordnande inte blir beroende av arvingarnas eller testamentstagarnas agerande efter dödsfallet.

\subsection{Artikel 3}

Föreslagen lydelse

"En arvlåtare får förordna att rätten till arv efter honom eller henne ska styras av lagen i den fördragsslutande stat där han eller hon vid tidpunkten för förordnandet eller vid sin död är medborgare.

En arvlåtare som är medborgare i flera fördragsslutande stater fär $v$ älja lagen $i$ en av de stater $i$ vilken han eller hon är medborgare vid tidpunkten för förordnandet eller vid sin död.

Om arvlåtaren har förordnat att lagen i en icke fördragsslutande stat ska tillämpas, prövas lagvalsförordnandets giltighet $i$ varje fördragsslutande stat enligt de där tillämpliga allmänna reglerna."

\section{Kommentar}

När arvlåtaren har förordnat om lagvalet, gäller förordnandet i stället för bestämmelserna i artikel 2. Arvlåtaren kan när som helst ändra förordnandet. Arvlåtarens lagvalsfrihet ersätter den rätt att bestämma över valet av tillämplig lag som arvingar och testamentstagare har enligt den gällande lydelsen av arvskonventionen. Förslaget är begränsat till situationer där den utpekade lagen är lagen i en fördragsslutande stat. Denna begränsning har motiverats ovan i avsnitt 6.3. Argumenten till stöd för arvlåtarens lagvalsfrihet har presenterats i avsnitt 6.5 ovan. Om arvlåtaren har förordnat om tillämpning av en icke fördragsslutande stats lag avgör de allmänt tilllämpliga reglerna i varje stat huruvida valet är tillåtet eller inte.

Den föreslagna lydelsen av art. 3 följer i väsentliga hänseenden den motsvarande regeln i art. 22 i EU:s arvsförordning. Det var Europaparlamentet som föreslog att arvlåtaren ska kunna välja lagen i det land där han eller hon är medborgare vid tidpunkten för lagvalsförordnan- 
det eller vid sin död. ${ }^{29}$ Från nordisk synpunkt, särskilt med beaktande av de många valmöjligheter som den reviderade äktenskapskonventionen ger för makar vad gäller förmögenhetsförhållanden i äktenskap, är denna utvidgning i förhållande till kommissionens förslag ett välkommet tillägg.

Liksom i art. 2 talas det i art. 3 allmänt om rätten till arv för att markera att förfarandefrågor i internordiska situationer kan vara att bedöma enligt den nordiska arvskonventionens särskilda regler om saken. Såsom framgått av kommentaren till art. 2 gör expertgruppen den bedömningen att en sådan tolkning är fullt möjlig att dra från det till Sverige och Finland beviljade undantaget i art. 75.3 i arvsförordningen. Om sålunda arvlåtaren har förordnat om tillämpning av en sådan fördragsslutande stats lag som enligt arvskonventionens art. 19 inte gäller för förfarandefrågorna, så styrs de senare frågorna av den av art. 19 utpekade lagen.

Artikelns andra stycke förtydligar att i de fall där arvlåtaren är medborgare i fler än en fördragsslutande stat omfattar de i första stycket angivna valmöjligheterna var och en av dessa staters lagar. Förslaget följer även i detta hänseende arvsförordningen (art. 22 st. 2), men är begränsat till situationer där arvlåtaren är medborgare i olika nordiska stater.

Om arvlåtaren har förordnat om tillämpning av en icke fördragsslutande stats lag, på grund av att han eller hon vid tidpunkten för förordnandet eller vid sin död hade medborgarskap (även) där, gäller enligt tredje stycket i var och en av de nordiska staterna de allmänt tillämpliga bestämmelserna. Enligt expertgruppens mening är en sådan lösning given. Det kan dock anses ha ett särskilt värde att en uttrycklig bestämmelse för en sådan situation tas med i konventionen. Lösningen har en förebild i arvskonventionens art. 8.4 som kom till när konventionen sågs över år 1975 (se nedan avsnitt 7.5).

När ett lagvalsförordnande har gjorts enligt konventionen fortsätter det att vara giltigt enligt konventionen när arvlåtaren flyttar till en annan fördragsslutande stat eller blir medborgare i en annan fördragsslutande stat. Lagvalsförordnandet gäller även när arvlåtaren flyttar tillbaka och får hemvist i den fördragsslutande stat där han eller hon är medborgare. Det följer av art. 3 att endast en stats lag kan förordnas vara tillämplig. Arvlåtaren kan sålunda inte bestämma att olika delar av kvarlåtenskapen är att bedöma enligt olika länders lagar. Också enligt arvsförordningen kan arvlåtarens lagvalsförordnande avse bara en stats lag i taget.

${ }^{29}$ Se Addentum to Note, by the Presidency to Coreper, Brussels, 20 February 2012, 6557/12, ADD 1, LIMITE, JUSTCIV 61, CODEC 392. 


\subsection{Artikel 3a}

Föreslagen lydelse

"Ett förordnande om tillämplig lag ska ges i den form som gäller för testamente för att vara giltigt eller framgå av villkoren i ett testamente. En àterkallelse av förordnandet ska för att vara giltig göras i den form som gäller för återkallelse av testamente. Vid prövningen av förordnandets eller återkallelsens giltighet till formen iakttas det som sägs i artikel 8."

\section{Kommentar}

Artikeln anger under vilka förutsättningar ett förordnande om tilläm plig lag och en återkallelse av ett sådant förordnande är giltiga till formen. Frågan om när ett sådant förordnande är giltigt i materiellt avseende bestäms däremot enligt artikel 3. I vissa fall kan även artikel 3b vara av betydelse.

Bestämmelsen motsvarar art. 22.2 i arvsförordningen, men har också inspirerats av en liknande lösning i de allmänt tillämpliga finska reglerna (se ovan avsnitt 5.2). Den innebär att samma formkrav tillämpas för ett förordnande om tillämplig lag som i fråga om formkraven för testamente. Motsvarande gäller för återkallelse av förordnandet.

Ett lagvalsförordnande eller en återkallelse av ett sådant förordnande är, på grund av hänvisningen i art. 3a, formellt giltigt om förordnandet eller återkallelsen uppfyller formkraven för ett testamente i någon av de lagar som anvisas i art. 8. När fråga uppstår om tillämpning av en icke fördragsslutande stats lag hänvisar art. 8.4 till de allmänt tilllämpliga reglerna i varje nordisk stat. Art. 8 avviker på det sättet från ett traditionellt internordiskt lagvalssystem där valet sker mellan de nordiska ländernas lagar. Artikeln fick sin nuvarande lydelse i anledning av de nordiska ländernas, förutom Islands, tillträde till 1961 års Haagkonvention om tillämplig lag för formen av testamentariska förordnanden. Haagkonventionens syfte var att i möjligaste mån, genom att utpeka flera olika alternativt tillämpliga lagar, upprätthålla ett testamentes eller återkallelses - giltighet till formen.

För att undvika senare svårigheter vid tolkningen är det önskvärt att arvlåtaren uttryckligen i sitt testamente anger den tillämpliga lagen för kvarlåtenskapens överföring. Detta är dock inte en förutsättning för att ett lagvalsförordnande som arvlåtaren gjort ska vara giltigt, utan det räcker med att det vid tolkning av ett testamente framgår att arvlåtaren har avsett att en viss stats lag ska tillämpas. Enligt art. 3 a ska det framgå av villkoren för ett testamente att arvlåtaren avsett en viss stats lag vara tillämplig, när ett uttryckligt lagvalsförordnande inte har gjorts. 


\subsection{Artikel 3b}

Föreslagen lydelse

"En fördragsslutande stat får bestämma att ett sådant lagvalsförordnande som avses i artikel 3, av en arvlåtare med hemvist i den staten vid tidpunkten för förordnandet, vid ett arvskifte i denna stat är verksamt mot arvlåtarens make eller sambo endast om förordnandet meddelas den maken eller sambon."

\section{Kommentar}

Enligt denna bestämmelse har en fördragsslutande stat möjlighet att göra lagvalsförordnandets giltighet i förhållande till arvlåtarens make eller sambo beroende av att förordnandet har meddelats maken eller sambon. En förutsättning för ett sådant krav är att arvlåtaren vid tidpunkten för lagvalsförordnandet hade hemvist i den staten. Det gäller inte om hemvistet vid tidpunkten för ett annars giltigt lagvalsförordnande fanns i en annan fördragsslutande stat som inte ställer motsvarande krav. Var den efterlevande maken eller sambon har eller har haft sitt hemvist saknar relevans.

Artikeln har kommit till på norskt initiativ. Enligt norsk rätt ska ett testamente, som inkräktar på makens/sambons legala arvsrätt, delges denne under arvlåtarens livstid, utom när det är omöjligt eller stöter på orimliga svårigheter. ${ }^{30} \mathrm{Om}$ testamentet inte har delgetts maken/sambon och testamentet inkräktar på den efterlevande makens/sambons legala arvsrätt är testamentet i motsvarande mån ogiltigt. Utgångspunkten är att ett lagvalsförordnande kan, på samma sätt som ett testamente, missgynna arvlåtarens efterlevande make eller sambo. Således förutsätts det, för att bestämmelsen ska ha relevans, att lagvalsförordnadet medför att maken/sambon får mindre än vad han eller hon eljest skulle ha fått.

Bestämmelsen har utformats med ledning av art. 4 tredje stycket i äktenskapskonventionen. Enligt denna kan var och en av staterna göra giltigheten av ett lagvalsavtal eller ett äktenskapsförord gentemot tredje man beroende av att avtalet eller förordet registreras enligt dess lag. Art. $3 \mathrm{~b}$ har ingen motsvarighet i arvsförordningen vilket medför att Finland eller Sverige inte kan ställa sådana här krav för giltighet av ett lagvalsförordnande.

Expertgruppen anser att det i ett senare skede bör övervägas om det behövs en särskild bestämmelse som förpliktar en fördragsslutande stat, som vill göra bruk av möjligheten enligt artikel $3 \mathrm{~b}$, att i samband med

${ }^{30}$ Se arveloven 7 och $28 c £ \S$. Även rätten till oskifte skyddas. 
sin ratificering av ändringskonventionen meddela detta i form av en deklaration.

\subsection{Artikel 4 - (upphävd 1975)}

\subsection{Artikel 5}

Föreslagen lydelse; "Artikel 5 upphävs."

\section{Kommentar}

Artikel 5 i konventionens nuvarande lydelse avser efterlevande makes rätt att sitta i oskiftat bo med adoptivbarn eller dess avkomling. Enligt förslaget i övrigt ska särskilda lagvalsregler i konventionen utgå avseende skydd för efterlevande make. Ställningstagandet har motiverats ovan under avsnitt 6.6. Med hänsyn till detta saknas det anledning att ha en särregel som avser rätten till oskiftat bo när det finns adoptivbarn eller avkomling till adoptivbarn.

\subsection{Artikel 6}

Föreslagen lydelse; "Artikel 6 upphävs."

\section{Kommentar}

Artikel 6 i konventionens nuvarande lydelse ålägger arvinge, testamentstagare eller efterlevande make som yrkar tillämpning av lagen i den fördragsslutande stat där den avlidne var medborgare att visa att förutsättningarna för tillämpning av hemlandets lag är för handen och att även styrka innehållet i den lagen. Med "hemlandets lag" avses i konventionen lagen i den fördragsslutande stat där den avlidne var medborgare vid sin död.

Bestämmelsen kan ses mot bakgrund av att tillämpning av "hemlandets lag" innebär enligt konventionens nuvarande lydelse en avvikelse från huvudregeln om tillämpning av hemviststatens lag, som i sin tur sammanfaller med tillämpning av lex fori. Vidare, tillämpning av "hemlandets lag" kan aktualiseras endast på initiativ av en intresserad arvinge, testamentstagare eller efterlevande make; i annat fall gäller lagen i den stat där den avlidnes sista hemvist fanns. Bestämmelsen avser att finna en praktiskt fungerande lösning i en situation där de efterlevande kan vara intresserade av att sätta konventionens huvudregel ur spel. Den som yrkar tillämpning av "hemlandets lag" måste visa att hans eller hennes egen rätt är beroende av det.

Enligt de av expertgruppen föreslagna bestämmelserna kan tillämpning av en annan fördragsslutande stats lag förväntas bli mer vanlig. 
Detta gäller särskilt när arvlåtaren har gjort bruk av sin rätt att förordna om tillämplig lag. Med hänsyn till att de efterlevande enligt förslaget inte kan yrka tillämpning av en annan stats lag fyller artikeln inte längre den avsedda funktionen. Därför bör den upphävas.

\section{Följdändring: Slutprotokollet bör upphävas}

En följdändring av att artikel 6 upphävs blir att det även saknas anledning att behålla konventionens slutprotokoll. Protokollet anger behörig myndighet i staterna för att förmedla och motta framställningar om upplysningar om innehållet i annan fördragsslutande stat gällande lag. Frågan om hur innehållet i en annan fördragsslutande stats lag utreds och styrks, när domstolen inte känner till det, lämnas lämpligen över till allmänt tillämpliga processuella föreskrifter i länderna. ${ }^{31}$ Expertgruppen föreslår därför att protokollet upphävs. Enligt uppgift av det svenska utrikesdepartementet används vid upphävande av ett protokoll samma form som vid dess tillkomst.

\subsection{Artikel 7}

Föreslagen lydelse; "Artikel 7 upphävs."

\section{Kommentar}

Enligt artikel 7 i konventionens nuvarande lydelse ska vid bodelning iakttas vad som stadgas enligt artiklarna 3 och 6 i den nordiska äktenskapskonventionen. Hänvisningen avser den sistnämnda konventionens tidigare lydelse. Det följer att bestämmelsen inte längre fyller den avsedda funktionen sedan äktenskapskonventionen ändrats år 2006 och att hänvisningen blir missvisande.

Av betydelse är även att arvskonventionens tillämplighetskriterier är vidare än äktenskapskonventionens. Arvskonventionen tar sikte på arvlåtarens medborgarskap och hemvist vid tidpunkten för döden, medan äktenskapskonventionen även fäster vikt vid var makarna var medborgare och var de tog hemvist vid äktenskapets ingående. Det kan sålunda inträffa att tillämplig lag för arvet, när en gift arvlåtare dör, är att bedöma enligt arvskonventionen medan tillämplig lag för makarnas förmögenhetsförhållanden bedöms enligt de allmänt tillämpliga reglerna i varje fördragsslutande stat. Det är svårt att se vilket syfte en bestämmelse som den gällande i så fall skulle uppfylla. Därför föreslås artikeln bli upphävd.

\footnotetext{
31 I Sverige: 35 kap. 2 § 2 st. rättegångsbalken; i Finland: 17 kap. 3 §ättegångsbalken; i Norge: Lov 2005-06$17 \mathrm{nr} 90$ om mekling og rettergang i sivile tvister (tvisteloven) § 11-3. Dansk och isländsk rätt har motsvarande praxisbildade regler.
} 


\subsection{Artikel 8}

Föreslagen lydelse

"Arvlåtarens testamente anses giltigt till formen, om testamentet i fråga om formen uppfyller vad som föreskrivs i lagen på ort där testamentet upprättades eller testator vid upprättandet eller vid sin död hade hemvist eller lagen $i$ stat där testator vid upprättandet eller vid sin död var medborgare. Såvitt testamente avser fast egendom ska det också anses giltigt till formen, om testamentet i fråga om formen uppfyller vad som föreskrivs i lagen på den ort där egendomen finns.

Första stycket har motsvarande tillämpning i fråga om ändring eller återkallelse av testamente. Återkallelse ska också anses giltig till formen, om återkallelsen i fråga om formen uppfyller vad som föreskrivs i lag enligt vilken det återkallade testamentet på grund av vad som sägs i första stycket var giltigt till formen.

Hade testator enligt lagen i icke fördragsslutande stat domicil i den staten, fär detta domicil åberopas $i$ stället för hemvist $i$ fall som avses $i$ första eller andra stycket.

Uppstår i övrigt enligt första, andra eller tredje stycket fråga om tilllämpning av lagen i icke fördragsslutande stat, tillämpas de allmänna regler som härom gälla i varje fördragsslutande stat."

\section{Kommentar}

I och med att kriterierna för konventionens tillämpning uttrycks tydligt redan i konventionens art. 1, i den nu föreslagna lydelsen, făr detta konsekvenser även för tillämpningen av de övriga artiklarna. Artikel 8 har justerats så att den är i linje med ändringen. De föreslagna ändringarna är genomgående renodlat redaktionella följdändringar. Såsom framgått (avsnitt 7.5) bygger art. 8 i allt väsentligt på 1961 års Haagkonvention om tillämplig lag för formen av testamentariska förordnanden. Arvsförordningen ska inte påverka Haagkonventionens tillämpning mellan de EU-stater som är parter till denna konvention. ${ }^{32}$

32 Se art. 75.1 andra stycket i arvsförordningen. 


\subsection{Artikel 9}

Föreslagen lydelse

"En fråga om arvlåtarens behörighet att upprätta eller återkalla ett testamente ska bedömas enligt lagen i den fördragsslutande stat vars lag enligt artikel 2 eller 3 ska tillämpas i fråga om rätt till arv efter den döde. Arvlåtaren ska också anses ha haft behörighet att upprätta eller återkalla testamentet om han eller hon hade sådan behörighet enligt lagen $i$ den fördragsslutande stat där han eller hon vid tidpunkten för upprättandet eller återkallelsen hade hemvist. Om arvlåtaren vid den aktuella tidpunkten hade hemvist $i$ en icke fördragsslutande stat tillämpas de allmänna regler som gäller i varje fördragsslutande stat."

\section{Kommentar}

Enligt förslaget ska behörigheten att upprätta eller återkalla testamente i första hand bedömas enligt den fördragsslutande stats lag som enligt art. 2 eller 3 ska tillämpas i fråga om rätten till arv. Härutöver ska arvlåtaren enligt förslaget anses ha varit behörig om behörighet följer av lagen i den fördragsslutande stat där arvlåtaren vid tidpunkten för upprättandet eller återkallelsen hade hemvist. Noteras bör att frågan enligt arvsförordningen kan regleras av den lag som enligt förordningen skulle ha varit tillämplig på arvet om testatorn avlidit samma dag som testamentet eller återkallelsen upprättades, vilket kan leda till att en annan lag blir tillämplig. ${ }^{33}$

I händelse av att arvlåtaren vid den aktuella tidpunkten haft hemvist i en icke fördragsslutande stat ska frågan i stället prövas enligt de allmänt tillämpliga reglerna i varje fördragsslutande stat. En sådan lösning är i linje med att förslaget även i övrigt ger visst utrymme för tillämpning av de allmänt gällande reglerna i varje fördragsslutande stat.

\subsection{Artikel 10}

Föreslagen lydelse

"Fråga om testamentets eller återkallelsens ogiltighet på grund av testators sinnestillstånd eller på grund av svek, villfarelse, tvång eller annan otillbörlig påverkan ska bedömas enligt lagen i den av staterna, där testatorn hade hemvist vid den tid då åtgärden vidtogs. Om testatorn vid den aktuella tidpunkten haft hemvist i en icke fördragsslutande stat tillämpas de allmänna regler som gäller i varje fördragsslutande stat."

${ }^{33}$ Art. 24 och 26. 


\section{Kommentar}

Expertgruppen har ansett att artikeln även framöver kan fylla en klargörande funktion. Artikeln föreslås därför vara kvar oförändrad, bortsett från att det läggs till en ny mening rörande situationer där testatorn vid den aktuella tidpunkten hade hemvist i en utomnordisk stat. Då ska frågan i stället prövas enligt de allmänt tillämpliga reglerna i varje fördragsslutande stat. Noteras bör att frågan enligt arvsförordningen kan regleras även av den lag som testatorn hade valt, vilket kan leda till att en annan lag blir tillämplig. ${ }^{34}$

\subsection{Artikel 11}

Föreslagen lydelse

"Hade medborgare i fördragsslutande stat vid sin död hemvist i Finland eller Sverige, ska där gällande lag tillämpas i fråga om klander av testamente.

Bestämmelser i norsk lag om att rätt på grund av testamente och invändningar mot giltigheten av testamente ska göras gällande inom vissa frister tillämpas också i fråga om testamente efter medborgare i annan fördragsslutande stat, om han eller hon vid sin död hade hemvist i Norge."

\section{Kommentar}

Bestämmelsen i artikelns första stycke kom ursprungligen till i anledning av att svensk och finsk rätt hade regler om både bevakning av testamente och klander av testamente medan sådana regler saknades i de övriga länderna. ${ }^{35}$ Syftet var att markera att de svenska eller finska reglerna om bevakning eller klander av testamente skulle gälla även när den avlidne var medborgare i en av de övriga staterna, förutsatt att det sista hemvistet fanns i Sverige eller Finland. Bestämmelsen ska även ses i samband med art. 19.1 enligt vilken boutredning ska ske i den av staterna i vilken den avlidne hade det sista hemvistet.

Första stycket har ändrats i förslaget på så sätt att det inte längre säger något om tillämplig lag i fråga om bevakning av testamente. Ändringen är motiverad av att det inte längre finns bestämmelser om bevakning av testamente i Finland och Sverige. I övrigt är det fråga om små redaktionella ändringar.

Enligt expertgruppen omfattas inte frågan om tillämplig lag vid klander av testamente av arvsförordningens lagvalsregler när frågan gäller förfaranderegler. När det gäller förfarandet vid klander av testamente kan Finland och Sverige därför tillämpa den aktuella bestämmelsen i

${ }^{34}$ Art. 24 och 26.

35 NJA II 1935:8, s. 382. 
första stycket. På materiella frågor tillämpas arvsförordningens bestämmelser.

Det andra stycket är i sak oförändrat. Bestämmelsen motiverades utifrån likadana hänsynstaganden som det första stycket. Bestämmelsen synes fortfarande vara motiverad av hänsyn till innehållet i norsk rätt. ${ }^{36}$

\subsection{Artikel 12}

Föreslagen lydelse

"Om arvlåtaren har ingått ett arvsavtal eller gett en gåva för dödsfalls skull ska avtalets eller gåvans bindande verkan bedömas enligt den stats lag som då enligt artikel 2 eller 3 gällde för rätten till arv efter honom eller henne.

Detsamma gäller fråga om egendom som arvinge mottagit av arvlåtaren under dennes livstid ska anses som förskott på arv.

Om fråga uppstår enligt första eller andra stycket om tillämpning av lagen $i$ en icke fördragsslutande stat tillämpas de allmänna regler som därom gäller i varje fördragsslutande stat."

\section{Kommentar}

Förslaget i första stycket ansluter sig i allt väsentligt till den nuvarande lydelsen i art. 12 första stycket. Eftersom enligt förslaget även en annan stats lag än lagen i den fördragsslutande stat där arvlåtaren har hemvist kan vara bestämmande för rätten till arv enligt artikel 2 eller 3, har första stycket justerats i motsvarande mån. Syftet är att säkerställa att en rätthandling (arvsavtal eller gåva för dödsfalls skull) som var giltig när den företogs är giltig även om tillämplig lag ändrats. Arvsavtal är idag giltiga enligt både norsk och dansk rätt.

Den formella lydelsen av bestämmelsen i andra stycket är i princip oförändrad. Eftersom flera lagar (och inte bara lagen i arvlåtarens dåvarande hemviststat) kan vara tillämpliga enligt expertgruppens förslag, kommer detta att även påverka tillämpningen av andra stycket.

Det tredje stycket har utformats i enlighet med förslagets art. 3 tredje stycket. När arvlåtaren vid den aktuella tidpunkten haft hemvist i en utomnordisk stat eller förordnat om tillämpning av sådan stats lag, avgörs rättshandlingens giltighet och rättsverkningar enligt de allmänna internationellt privaträttsliga bestämmelserna i varje fördragsslutande stat.

För Finlands och Sveriges del regleras de frågor som artikeln behandlar i EU:s arvsförordning, se dess art. 25 respektive 23.2 (i).

${ }^{36} \mathrm{Jmf}$ lov 3 mars 1972 nr. 5 § 70. 


\subsection{Artikel 13}

Ingen ändring.

\section{Kommentar}

Expertgruppen har diskuterat en eventuell modernisering av texten men stannade vid att behålla den ursprungliga lydelsen. Mer moderna exempel $^{37}$ (än fideikommissariskt förfogande) på bestämmelsens tillämplighet kan tas fram av var och en av staterna vid den nu föreslagna ändringskonventionens genomförande.

För Finlands och Sveriges del regleras frågan i EU:s arvsförordning, se dess art. 30.

\subsection{Artikel 14}

Ingen ändring.

\section{Kommentar}

Expertgruppen anser att regeln bör behållas eftersom det fortfarande finns adoptionsförhållanden med förbehåll i Danmark. Dessa adoptioner har genomförts före 1956. Även beträffande Island och Norge synes artikeln ha relevans. Regeln lämnas därför oförändrad.

Arvsförordningen medger dock inte att Finland och Sverige beaktar denna slags särreglering, utan de har att tillämpa arvsförordningens lagvalsregler även i denna fråga.

\subsection{Artikel 15}

Föreslagen lydelse ; "Artikel 15 upphävs."

\section{Kommentar}

Regeln utpekar tillämplig lag för förverkande av rätt att ta arv eller testamente efter en nordisk medborgare. Som tillämplig lag anges lagen i den fördragsslutande stat där arvlåtaren hade hemvist vid sin död. Artikeln föreslås bli upphävd. För detta talar att de nordiska ländernas lagar i dag är så pass lika ${ }^{38}$ att det inte finns behov av en särskild bestämmelse om saken. Frågan om förverkande av rätten till arv och testamente är att kvalificera som en materiell rättslig fråga som således är att bedöma

${ }^{37}$ Sådana finns t.ex. i den finska ärvdabalken

38 Se Peter Lødrup, Nordisk arverett. En sammenlignende studie av dansk, finsk, islandsk, norsk og svensk rett med drøftelser av harmoniseringsmuligheter og reformbehov. Nord 2003:3. 
enligt den lag som i övrigt gäller för arv och testamente. Frågan ska följaktligen enligt förslaget bedömas enligt den stats lag som utpekas som bestämmande av artikel 2 eller artikel 3 i förslaget. Samma lösning följer även av arvsförordningen. ${ }^{39}$

\subsection{Artikel 16}

Föreslagen lydelse

"På fråga om preskription av rätt att ta arv eller testamente efter en arvlåtare tillämpas lagen $i$ den stat som enligt artikel 2 eller 3 gäller för rätten till arv efter honom eller henne."

\section{Kommentar}

En särskild regel om preskription bör finnas kvar, bland annat därför att en sådan regel har ett särskilt informationsvärde. En följdändring har genomförts så att bedömningen sker enligt den lag som anges som tilllämplig enligt artikel 2 eller artikel 3 i förslaget. Den föreslagna lösningen är förenlig med den senare utvecklingen i internationell privaträtt som ger vid handen att preskription av krav är att kvalificera som en materiell rättslig fråga. Expertgruppen delar alltså denna bedömning.

Finland och Sverige har att tillämpa arvsförordningens bestämmelser i denna del, se dess art. 23.2 (b).

\subsection{Oförändrad rubrik för Avdelning II Den dödes gäld}

Rubriken föreslås vara kvar oförändrad.

\subsection{Artikel 17}

Föreslagen lydelse

"På fråga om arvinges eller testamentstagares ansvarighet för gäld efter en medborgare i fördragsslutande stat eller för fullgörande av legat eller ändamålsbestämmelse enligt den dödes testamente tillämpas lagen $i$ den fördragsslutande stat där han eller hon hade hemvist vid sin död."

${ }^{39}$ Se art. 23.2 (d). 


\section{Kommentar}

Några redaktionella ändringar har genomförts i den första meningen som dock i sak är oförändrad. Andra meningen i den nuvarande lydelsen föreslås bli upphävd som obsolet. Bestämmelsen avser ett särskilt ansvar för underhåll av barn födda utom äktenskap eller för barnets mor.

Finland och Sverige har att tillämpa arvsförordningens bestämmelser i denna del, se bl.a. dess art. 23.2 (g).

\subsection{Artikel 18}

Föreslagen lydelse

"Kallelse på okända borgenärer, som utfärdats under boutredning efter medborgare i fördragsslutande stat är, om fordringen var känd och borgenären hade hemvist $i$ en annan fördragsslutande stat, utan verkan, om inte borgenären i tid fått särskilt meddelande om kallelsen och dess verkan eller annars känt till den."

\section{Kommentar}

Expertgruppen föreslår att ordet "proklama" i de svenska språkversionerna byts ut mot det synonyma uttrycket "kallelse på okända borgenärer", men behålls för de övriga språkversionerna. I övrigt är det fråga om mindre redaktionella ändringar.

Frågan om kallelse på okända borgenärer handlar ytterst om en borgenär kan göra sin fordran gällande mot dödsboet. Expertgruppen anser att mycket talar för att detta är en fråga av förfarandekaraktär. En sådan tolkning leder till att Finland och Sverige kan tillämpa den nu aktuella bestämmelsen i arvskonventionen.

\subsection{Oförändrad rubrik för Avdelning III Boutredning, bodelning och arvskifte}

Rubriken föreslås vara kvar, oförändrad.

\section{Kommentar}

Expertgruppen har funnit det svårt att bedöma i vilken utsträckning som bestämmelserna i detta kapitel (art. 19-26) borde ses över på grund av den rättsutveckling som skett i länderna sedan arvskonventionen antogs. Detta gäller särskilt artiklarna 22-26. Expertgruppen vill därför uppmana länderna att fästa särskild uppmärksamhet vid dessa bestämmelser vid en senare översyn av konventionen. 


\subsection{Artikel 19}

Föreslagen lydelse

"Boutredning, bodelning och arvskifte efter medborgare i fördragsslutande stat ska förrättas i enlighet med lagen i den fördragsslutande stat, där den döde hade hemvist. Om enligt den lagen en domstol eller annan myndighet ska medverka, ankommer det på domstol eller myndighet i den staten.

Där efterlevande make, som är medborgare i fördragsslutande stat, suttit i oskiftat bo och boet ska delas, förfars i enlighet med lagen i den stat, där han eller hon har eller vid sin död hade hemvist; och ska, om enligt den lagen en åtgärd ska vidtas av domstol, åtgärden ankomma på domstol i den staten.

Boutredning, bodelning och arvskifte ska även omfatta till boet hörande egendom som finns i annan fördragsslutande stat."

\section{Kommentar}

Lydelsen av artikeln har moderniserats, utan att någon saklig ändring $\mathrm{i}$ jämförelse med den gällande lydelsen är avsedd.

Enligt expertgruppens bedömning omfattas artikeln av undantaget $\mathrm{i}$ arvsförordningens art. 75.3 punkten a, enligt vilken Finland och Sverige får tillämpa (den reviderade) arvskonventionen i den mån den "föreskriver regler avseende förvaltningen av dödsboet såsom anges i konventionen och medverkan av myndigheter i de fördragsslutande staterna". ${ }^{40}$ Det följer att art. 19 även i Finland och Sverige kan fortsätta att gälla i de situationer som omfattas av konventionen, oavsett arvsförordningen i övrigt. Art. 19 återger en i länderna väletablerad och i den praktiska tillämpningen välfungerande lösning. Att den omfattas av undantaget i arvsförordningen är därför enligt expertgruppens mening ett viktigt skäl i sig för att ändringskonventionen antas.

Artikelns första stycke anger enligt vilket lands lag själva förfarandefrågorna är att bedöma vid boutredning, bodelning eller arvskifte efter en nordisk medborgare som även hade hemvist i en nordisk stat, alltså situationer som enligt art. 1 faller in under arvskonventionen. Av art. 19.1 följer att denna lag alltid är lagen i den nordiska stat där den avlidne vid sin död hade hemvist. Detta gäller även om en annan stats lag skulle vara tillämplig på de materiellträttsliga frågorna avseende arv eller testamente, primärt på grund av att arvlåtaren valt en annan stats lag som tilllämplig enligt den föreslagna art. $3.0 \mathrm{~m}$ den avlidne hade hemvist i en utomnordisk stat faller situationen utanför arvskonventionen och art. 19 är inte tillämplig.

40 Den engelska språkversionen hänvisar till "rules on the procedural aspects of estate administration as defined by the Convention and assistance in that regard by the authorities of the States Contracting Parties to the Convention." 
Artikelns andra stycke avser fördelning av dödsbo som lämnats oskiftat till förmån för en efterlevande make. Även i detta avseende bedömer expertgruppen att det ovan citerade undantaget i arvsförordningen är tillämpligt. Även här är det nämligen fråga om tillämplig lag beträffande förfarandet när efterlevande make suttit i oskiftat bo och boet ska delas.

Artikelns tredje stycke uttrycker vad som brukar kallas universalitetsprincipen, i bemärkelsen universell behörighet att ta hand om all dödsboegendom oavsett var den finns. Arvsförordningen bygger på samma synsätt, vilket framgår av bl.a. artikel 4 och ingressats 37. Det innebär dock inte nödvändigtvis att regleringen i arvsförordningen alltid går ihop med arvskonventionen. Arvsförordningens vidsträckta subsidiära jurisdiktionsregler ${ }^{41}$ kan undantagsvis medföra att Finland och Sverige ska utöva behörighet på ett sätt som strider mot arvskonventionens huvudprincip om universell behörighet gällande all kvarlåtenskap. Det bör framhållas att arvsförordningen ger en möjlighet att begränsa förfarandet när arvet efter den avlidne omfattar tillgångar belägna i en tredjestat. ${ }^{42}$

\subsection{Artikel 20}

Ingen ändring, förutom mindre redaktionella ändringar, har gjorts.

\section{Kommentar}

Expertgruppen har kommit fram till att artikeln fortfarande kan fylla en funktion. Den första meningen slår sålunda fast att den där avsedda rättigheten vid konventionens tillämpning är att betrakta som en processrättslig fråga som bedöms enligt domstolslandets lag i stället för den lag som gäller för förmögenhetsförhållandena i ett äktenskap eller avseende rätten till arv. Även den andra meningen synes fortfarande ha relevans för norsk rätts del och bör därför behållas.

Expertgruppen gör bedömningen att artikelns första mening innehåller en bodelningsregel som faller utanför arvsförordningens tillämpningsområde, se dess art. 1.2 (d). Arvsförordningen hindrar därför inte Finland och Sverige från att tillämpa den aktuella bestämmelsen. När det gäller artikelns andra mening gör expertgruppen bedömningen att det är en bestämmelse som endast har relevans för norsk del och som därför inte berör arvsförordningen. 


\subsection{Artikel 21}

Föreslagen lydelse

"Tvist om arv eller testamente efter medborgare i fördragsslutande stat, som hade hemvist i sådan stat, eller om efterlevande makes rätt eller om fordran mot dödsboet ska tas upp av domstol i den stat, enligt vars lag boutredning, bodelning och arvskifte enligt artikel 19 ska förrättas.

Äro parterna därom ense, må tvisten upptagas i annan fördragsslutande stat, dock ej där boet är föremål för behandling av domstol, testamentsexekutor, bobestyrer eller av domstol förordnad boutredningsman eller skiftesman eller tvisten avser klander av bodelning eller arvskifte $i$ sådant bo eller av testamente efter någon som hade hemvist i Finland eller Sverige, eller av bodelning eller arvskifte efter någon som hade hemvist i Finland."

\section{Kommentar}

Artikeln föreslås vara oförändrad i sak.

I andra stycket har enligt initiativ från Danmark och Norge dels "arvsdomstol" ersatts med "domstol", dels "bobestyrer" enligt dansk och norsk rätt lagts till för att bestämmelsen ska återspegla vilka som enligt gällande rätt i de nordiska länderna får fatta sig med boutredning.

Eftersom domsrättsfrågorna inte omfattas av undantaget $\mathrm{i}$ arvsförordningens art. 75.3 är Finland och Sverige förhindrade att tillämpa den nu aktuella artikeln i arvskonventionen. Även om de båda instrumenten har samma huvudregel - nämligen att domsrätten tillkommer den avlidnes hemviststat - innehåller arvsförordningen därutöver ytterligare domsrättsgrunder. I de fall där huvudregeln gäller kommer bedömningen dock att sammanfalla med arvskonventionens art. 21.

\subsection{Artikel 22}

Ingen ändring.

Enligt expertgruppen är det här fråga om myndighets medverkan vid förfarandet. Art 75.3 a) arvsförordningen är därför tillämplig och Finland och Sverige kan tillämpa konventionens regel. 


\subsection{Artikel 23}

Föreslagen lydelse

"Är dödsbo som avses i artikel 19 föremål för behandling av bobestyrer $i$ Danmark eller offentligt skifte i Island eller Norge, ska vad där stadgas om inskränkning i borgenärs rätt att utmätningsvis njuta betalning ur dödsbo äga tillämpning jämväl å egendom i annan fördragsslutande stat. Vad nu är sagt gälle dock ej då fråga är om utmätning för skatt eller annan allmän avgift, som pålagts i den staten, eller om fordrans uttagande ur egendom, som häftar såsom pant eller må kvarhållas till säkerhet för fordringen."

\section{Kommentar}

Artikeln föreslås vara oförändrad, bortsett från att "bobestyrer" enligt dansk rätt läggs till för att bestämmelsen ska återspegla gällande dansk rätt. Också enligt norsk rätt kan en "bobestyrelser" förordnas för att ta hand om boet. Eftersom ett sådant förordnande utgör ett led i det offentliga skiftet har det inte bedömts finnas anledning att göra en motsvarande ändring för norsk rätts del. I övrigt är det fråga om mindre redaktionella ändringar.

I de undantagsfall där det med hänsyn till bestämmelsen om subsidiär behörighet i arvsförordningen skulle kunna bli aktuellt för Finland och Sverige att komma in på dessa frågor bör enligt expertgruppen noteras att det här är fråga om dödsboförvaltning. Art 75.3 a) arvsförordningen är därför tillämplig och konventionens bestämmelser kan tillämpas.

\subsection{Artikel 24}

Föreslagen lydelse

"Är dödsbo som avses i artikel 19 föremål för behandling av bobestyrer i Danmark eller offentligt skifte i Island eller Norge, ska i fråga om förmånsrätt för fordran bestämmelserna i artikel 7 av konventionen den 7 november 1933 om konkurs äga motsvarande tillämpning."

\section{Kommentar}

Artikeln föreslås vara oförändrad, bortsett från att "bobestyrer" enligt dansk rätt läggs till för att bestämmelsen ska återspegla gällande dansk rätt. Det görs också några mindre redaktionella ändringar.

I de undantagsfall där det med hänsyn till bestämmelsen om subsidiär behörighet i arvsförordningen skulle kunna bli aktuellt för Finland och Sverige att komma in på dessa frågor bör noteras att enligt artikel 44 i rådets förordning (EG) nr 1346/2000 av den 29 maj 2000 om insolvensförfaranden, ersätter sagda förordning bl.a. nordiska konventionen 
angående konkurs undertecknad i Köpenhamn den 7 november 1933 mellan medlemsstaterna.

\subsection{Artikel 25}

Ingen ändring.

Regleringen faller utanför arvsförordningens tillämpningsområde, se t.ex. art 1.2 l). Finland och Sverige bör därför kunna fortsätta tillämpa den aktuella bestämmelsen.

\subsection{Artikel 26}

Ingen ändring.

Regleringen faller utanför arvsförordningens tillämpningsområde. Finland och Sverige bör därför kunna fortsätta tillämpa den aktuella bestämmelsen.

\subsection{Oförändrad rubrik för Avdelning IV Allmänna bestämmelser}

Rubriken föreslås vara kvar, oförändrad.

\subsection{Artikel 27}

Föreslagen lydelse

"Har domstol i fördragsslutande stat fattat beslut att dödsbo som avses i artikel 19 ska omhändertagas av domstolen, arvsdomstol, boutredningsman, bobestyrer eller testamentsexekutor, eller att boet ska bli föremål för utredning och skifte genom delägarnas försorg eller skiftas under medverkan av skiftesman, vare beslutet gällande i övriga fördragsslutande stater."

\section{Kommentar}

Artikelns första stycke är oförändrat bortsett från att det, enligt önskemål från Norge respektive Danmark även omfattar "domstolen" och "bobestyrer", det senare finns såväl i Danmark som i Norge. Andra stycket, som handlar om beslut om efterlevande makes rätt att sitta i oskiftat bo föreslås bli upphävt, eftersom konventionen inte avses reglera särskilt den efterlevande makens rätt till oskiftat bo. 
Expertgruppen gör den bedömningen att ett sådant beslut som avses i denna artikel omfattas av undantaget i art. 75.3 i arvsförordningen, i vart fall när de aktuella punkterna där läses tillsammans.

\subsection{Artikel 28}

Ingen ändring.

\section{Kommentar}

Den nu aktuella artikeln är av yttersta relevans för bedömning av innebörden av undantaget i arvsförordningens art. 75.3.

Enligt arvskonventionens art. 28 gäller i fråga om "erkännande och verkställighet av dom eller förlikning om rätt på grund av arv eller testamente, efterlevande makes rätt, boutredning eller skifte i anledning av dödsfall eller ansvarighet för den dödes gäld" lagen i den fördragsslutande stat där erkännande och verkställighet begärs. Denna bestämmelse är att läsa tillsammans med art. 1 i 1977 års nordiska konvention om erkännande och verkställighet av domar på privaträttens område, ${ }^{43}$ enligt vilken såväl erkännande som verkställighet av en annan konventionsstat dom, annat avgörande och förlikning ska ske enligt lagen i den konventionsstat där erkännande och verkställighet söks. Såsom påpekats (avsnitt 4.4) är den senare konventionen en ramkonvention som har införlivats genom särskild lagstiftning i var och en av staterna med undantag av Island där 1932 års nordiska domskonvention fortfarande gäller. ${ }^{44}$ I Danmark, Finland, Norge och Sverige tillämpas 1977 års konvention på ärvande under förutsättning att det rör sig om ett avgörande eller en förlikning i ett nordiskt land och att den avlidne vid sin död både var medborgare i en nordisk stat och hade hemvist i någon av staterna. ${ }^{45}$

Av artikel 28 följer alltså, med viss reservation för Island som omfattas av den äldre nordiska domskonventionen, att de övriga ländernas ovan angivna domar och förlikningar erkänns och verkställs på samma villkor som motsvarande inhemska avgöranden. Det krävs inte någon särskild prövning av huruvida i en nordisk stat meddelat avgörande gäller och kan verkställas i de övriga staterna. Avgörandena erkänns

\footnotetext{
${ }^{43}$ Konventionen mellan Sverige, Danmark, Finland, Island och Norge om erkännande och verkställighet av domar på privaträttens område, Köpenhamn 11.10.1977.

${ }_{44}$ Konventionen mellan Sverige, Danmark, Finland, Island och Norge om erkännande och verkställighetet av domar. Köpenhamn 16.3.1932.

45 I Danmark gäller bekendtgørelse nr. 39 af 7 juni 1978 LTC, i Finland gäller lagen om erkännande och verkställighet av nordiska domar angående privaträttsliga anspråk (588/1977), i Norge tillämpas lov 10 juni 1977 nr. 71 om anerkjennelse og fullbyrdelse av nordiske dommer på privatrettens område och i Sverige gäller lagen (1977:595) om erkännande och verkställighet av nordiska domar på privaträttens område.
} 
automatiskt och deras verkställighet i ett annat nordiskt land följer de där gällande inhemska reglerna.

Enligt arvsförordningens art. 75.3 punkten b ska Finland och Sverige vara oförhindrade att tillämpa sådana regler i den (reviderade) arvskonventionen som föreskriver "enklare och snabbare förfaranden för erkännande och verkställighet av domar i samband med arv". Denna eftergift talar enligt expertgruppens mening för att revideringskonventionen antas av länderna. I annat fall kommer särskilda regler om bland annat exekvatur att gälla mellan Sverige och Finland på det aktuella området.

Expertgruppen vill samtidigt påpeka att relationen mellan arvsförordningen och arvskonventionens art. 28 inte är helt oproblematisk. Den potential till konflikter mellan domsrättsregleringen enligt arvskonventionen, å ena sidan, och enligt arvsförordningen, å andra sidan, berörs träffande av det följande exemplet:

En finsk medborgare med hemvist i Norge avlider och tvist uppstår om arv och testamente. Enligt arvskonventionen finns behörighet i Norge, på grund av den avlidnes hemvist där. Den avlidnes arvingar utnyttjar emellertid den vida domsrättsregleringen i arvsförordningen och väcker talan i Finland. Finsk domstol har domsrätt enligt arvsförordningens regler om subsidiär behörighet (art. 10, förutsatt att den avlidna har några tillgångar i Finland). Eftersom Finland inte har något undantag angående behörighetsreglerna, är finska myndigheter skyldiga att följa arvsförordningen och ta upp målet. Finland gör sig inte heller då skyldigt till konventionsbrott, eftersom arvskonventionens bestämmelser, enligt art. 1 i den reviderade arvskonventionen, gäller i Finland endast om inte annat följer av arvsförordningen.

Som art. 28 är utformad är Norge skyldigt att erkänna och verkställa det finska avgörandet.

Antag att målet redan pågår vid norsk domstol när en arvinge vill väcka talan i Finland. Bedömningen blir i vart fall i utgångsläget densamma som ovan, eftersom arvsförordningens bestämmelser om litis pendens är begränsade till mål inom sådana medlemsstater i EU som omfattas av förordningen. Helt kan man dock inte utesluta att arvsförordningens art. 12 (om s.k. begränsade förfaranden) skulle ge finsk domstol anledning att inte fatta beslut om tillgångarna i Norge. Denna begränsning av förfarandet i Finland förutsätter att det kan antas att Norge inte kommer att erkänna eller verkställa det finska avgörandet. Skillnaden mellan fallen skulle vara att Norge, på grund av att förfarandet först inletts där, inte anser sig kunna erkänna det finska avgörandet.

I gengäld, tolkar expertgruppen läget så att om ett lagakraftvunnet avgörande finns från de övriga nordiska länderna är Finland och Sverige bundna enligt art. 28 att erkänna och verkställa avgörandet under de ovan specificerade villkoren, även om det enligt arvsförordningen skulle ha funnits behörighet att ta upp målet i Finland eller Sverige. I annat fall skulle art. 28 lätt sättas ur spel. 
En viss osäkerhet råder, som de nordiska länderna måste lära sig hantera. Denna osäkerhet synes dock uppstå så fort som arvsförordningen träder i kraft. När viss praktisk erfarenhet erhållits av eventuella olägenheter kan det bli anledning att de nordiska länderna tar upp frågan till behandling. Det kan då exempelvis bli aktuellt att överväga om Danmark, Island och Norge kan införa interna föreskrifter om vissa speciella villkor för erkännande och verkställighet av svenska och finska avgöranden i här identifierade konfliktsituationer.

\subsection{Artikel 29}

Ingen ändring.

\section{Kommentar}

Enligt art. 29 gäller konventionen inte när arvlåtaren har dött före konventionens ikraftträdande. Den gäller inte heller när en efterlevande make har suttit i oskiftat bo när den först avlidne maken dog före denna tidpunkt. Även om sådana fall kan antas vara ytterst sällsynta där dödsfallet har inträffat innan konventionen trädde ikraft har expertgruppen bedömt att bestämmelsen bör behållas.

\subsection{Artikel 30}

Ingen ändring.

\section{Kommentar}

Enligt denna artikel ska konventionen ratificeras och ratificeringshandlingarna deponeras hos det danska utrikesministeriet. Artikeln anger vidare när konventionen träder i kraft mellan de ratificerande staterna.

Enligt expertgruppens mening ska övergångsbestämmelser tas med i ändringskonventionen. En lämplig lösning synes vara att bestämmelserna i ändringsöverenskommelsen inte gäller i de fall där arvlåtaren har avlidit innan överenskommelsen har trätt i kraft. 

8. Bilaga:

Överenskommelse om

ändring i den nordiska

arvskonventionen

(1 juni 2012) 


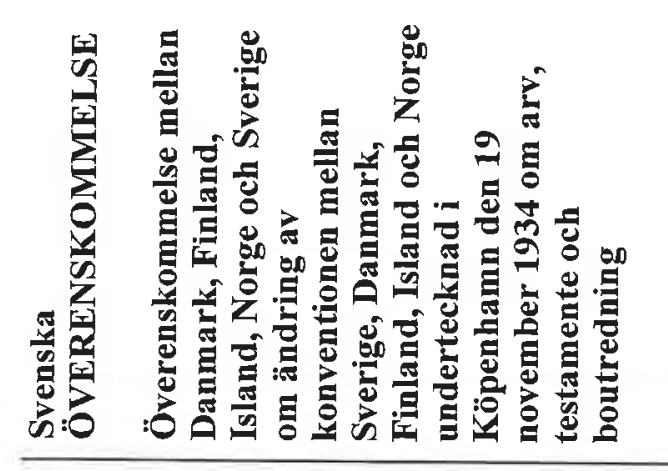

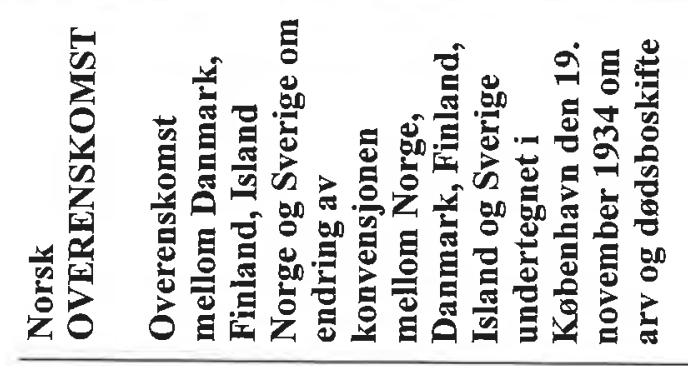
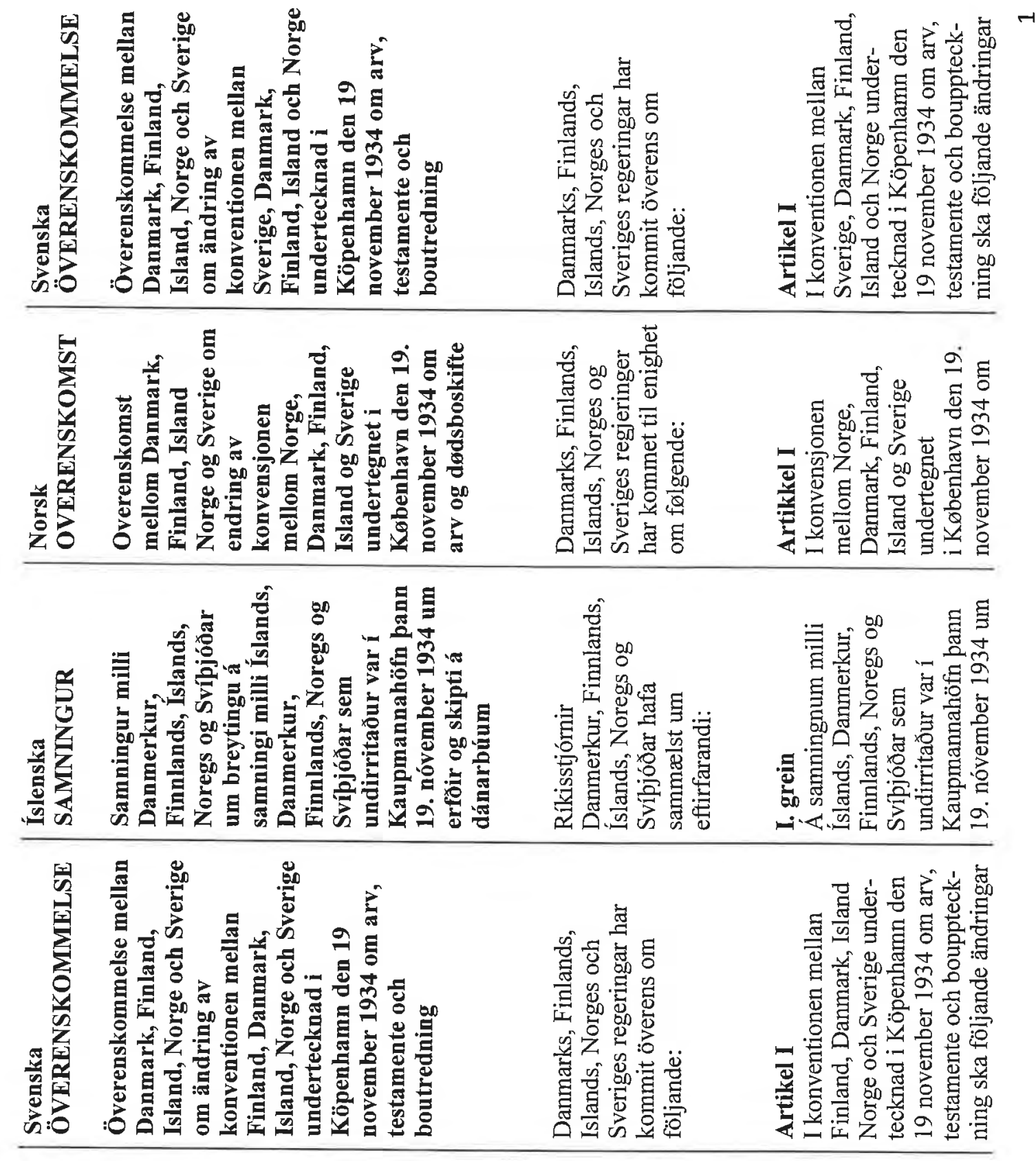

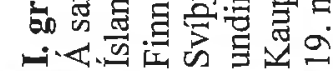
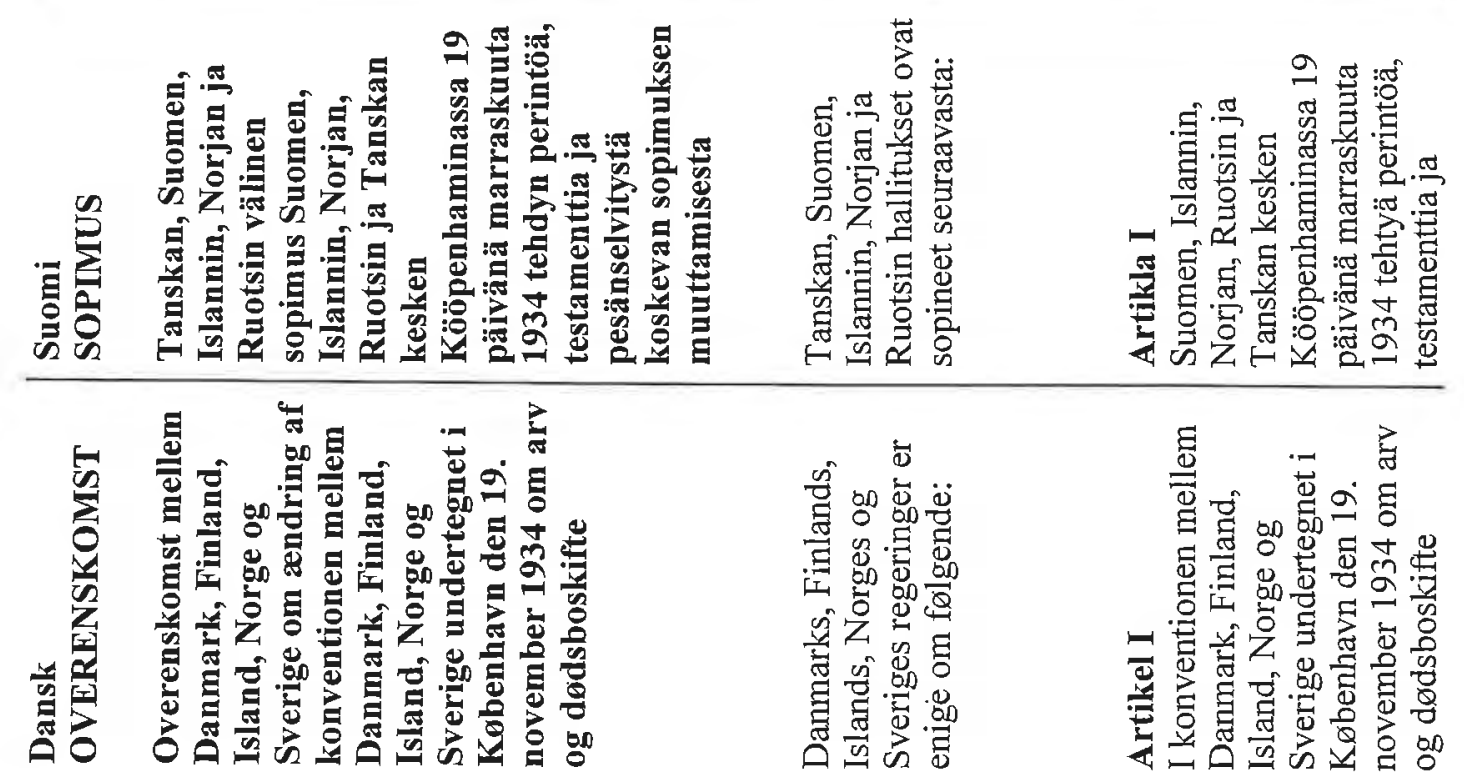

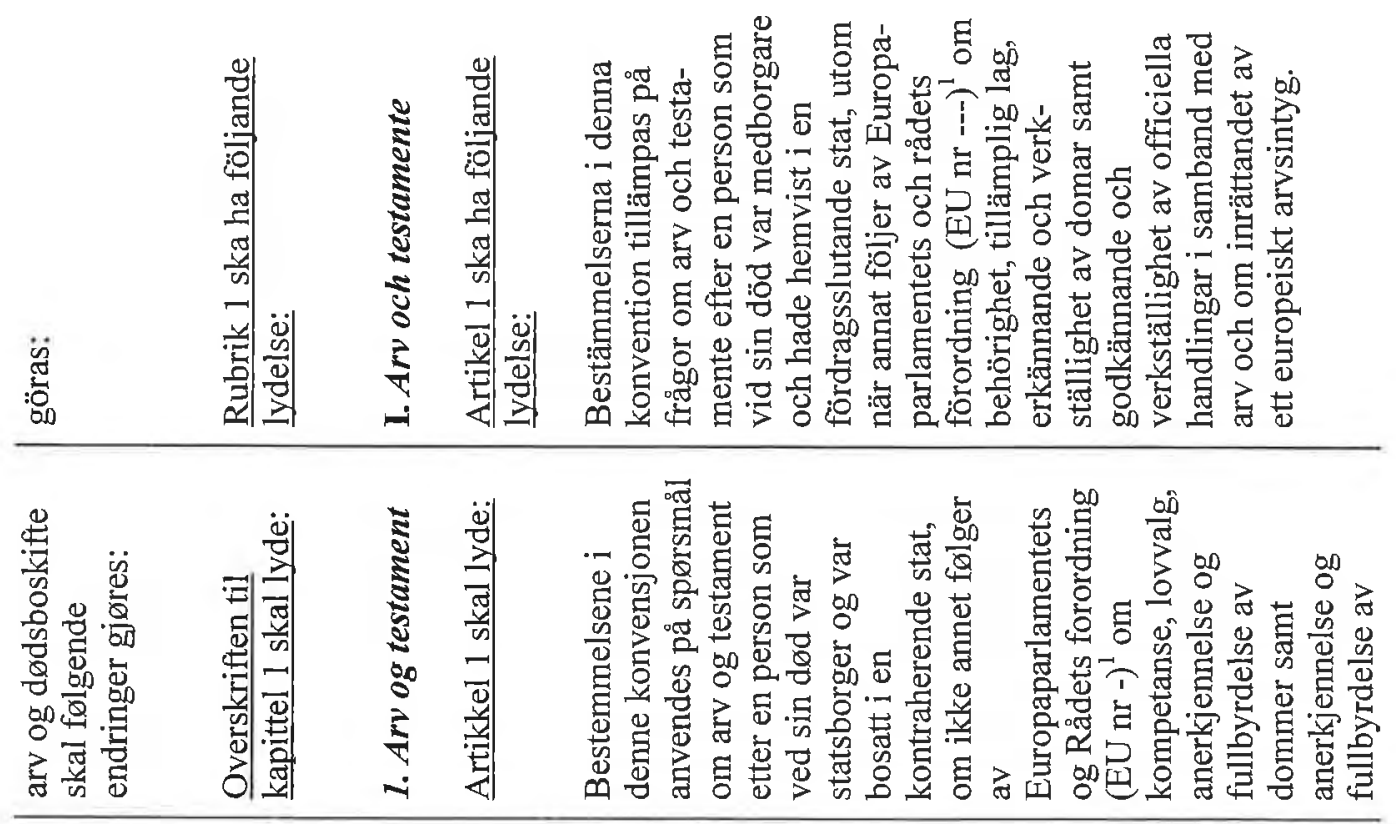

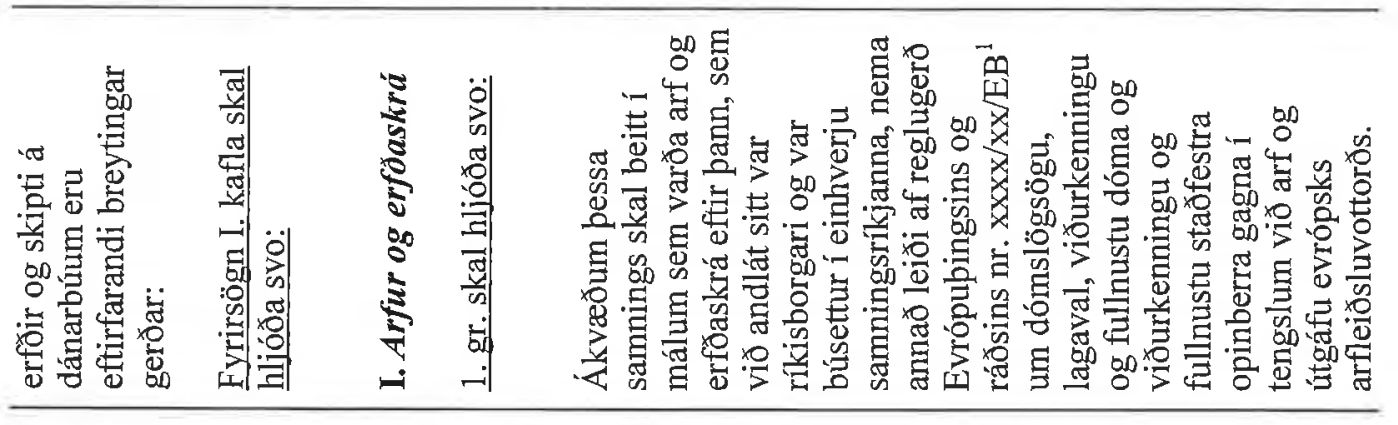
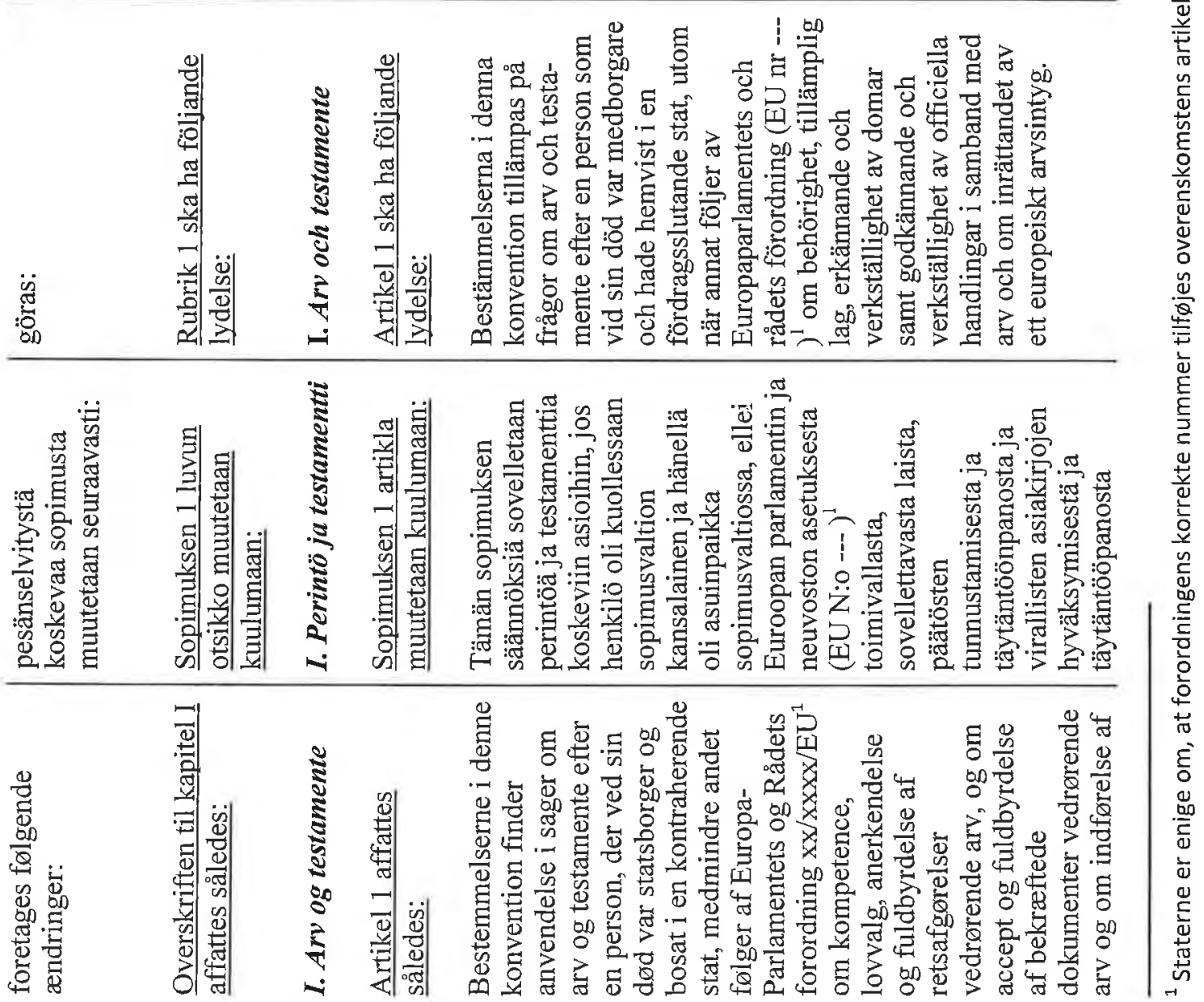


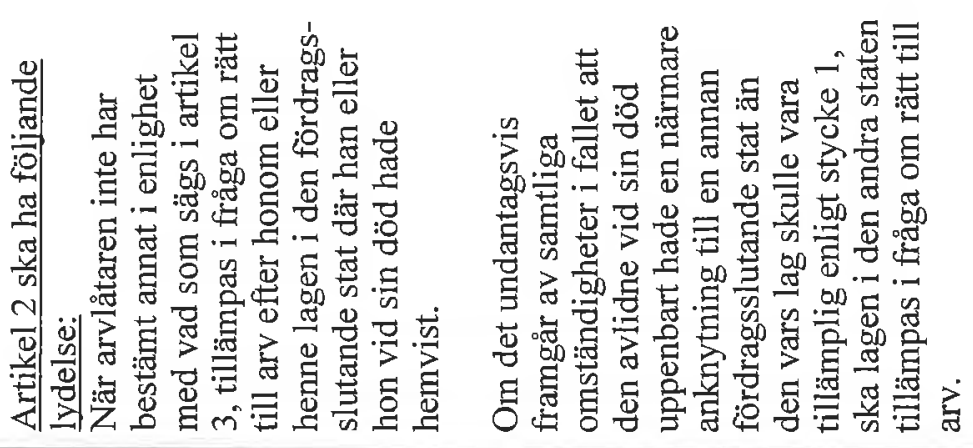

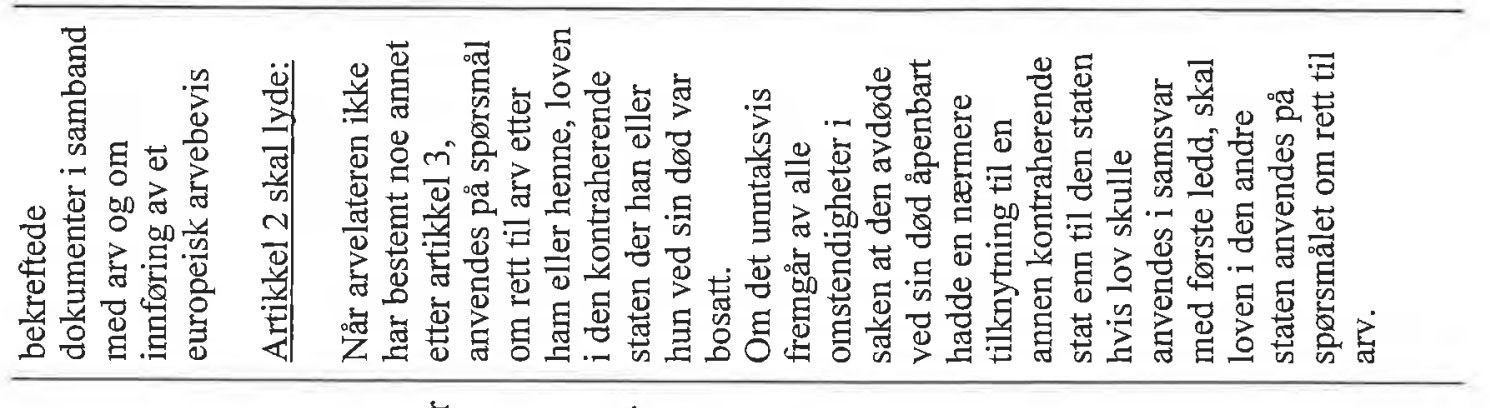

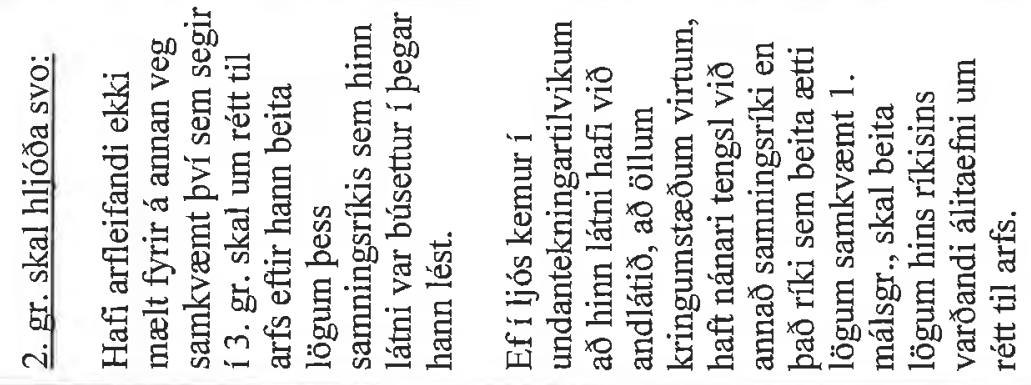

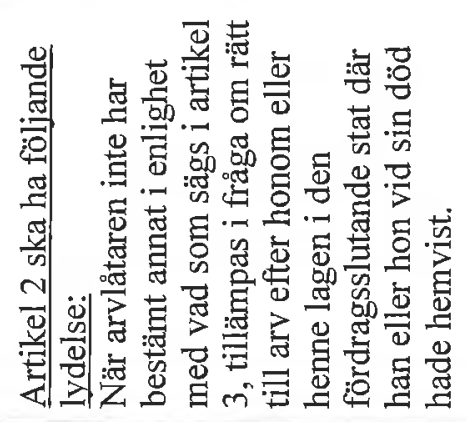

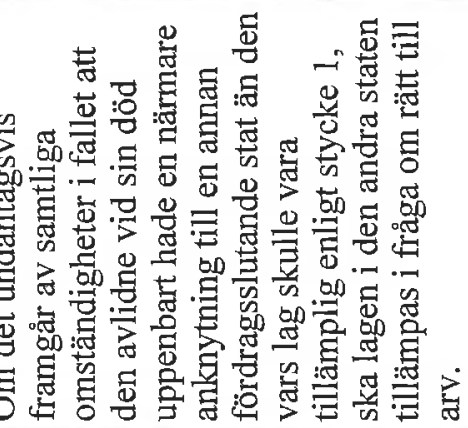

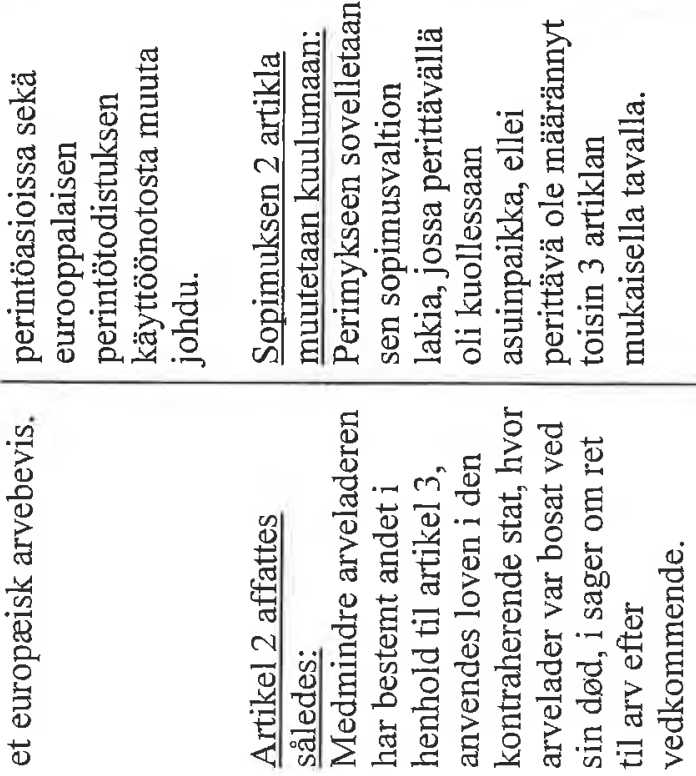

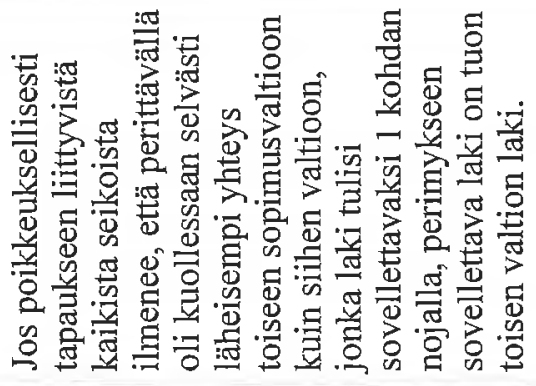

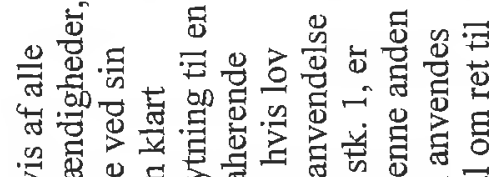

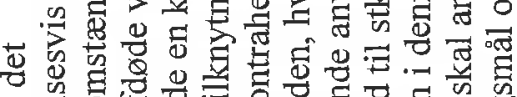
解 舟吅

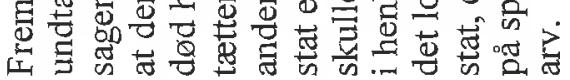



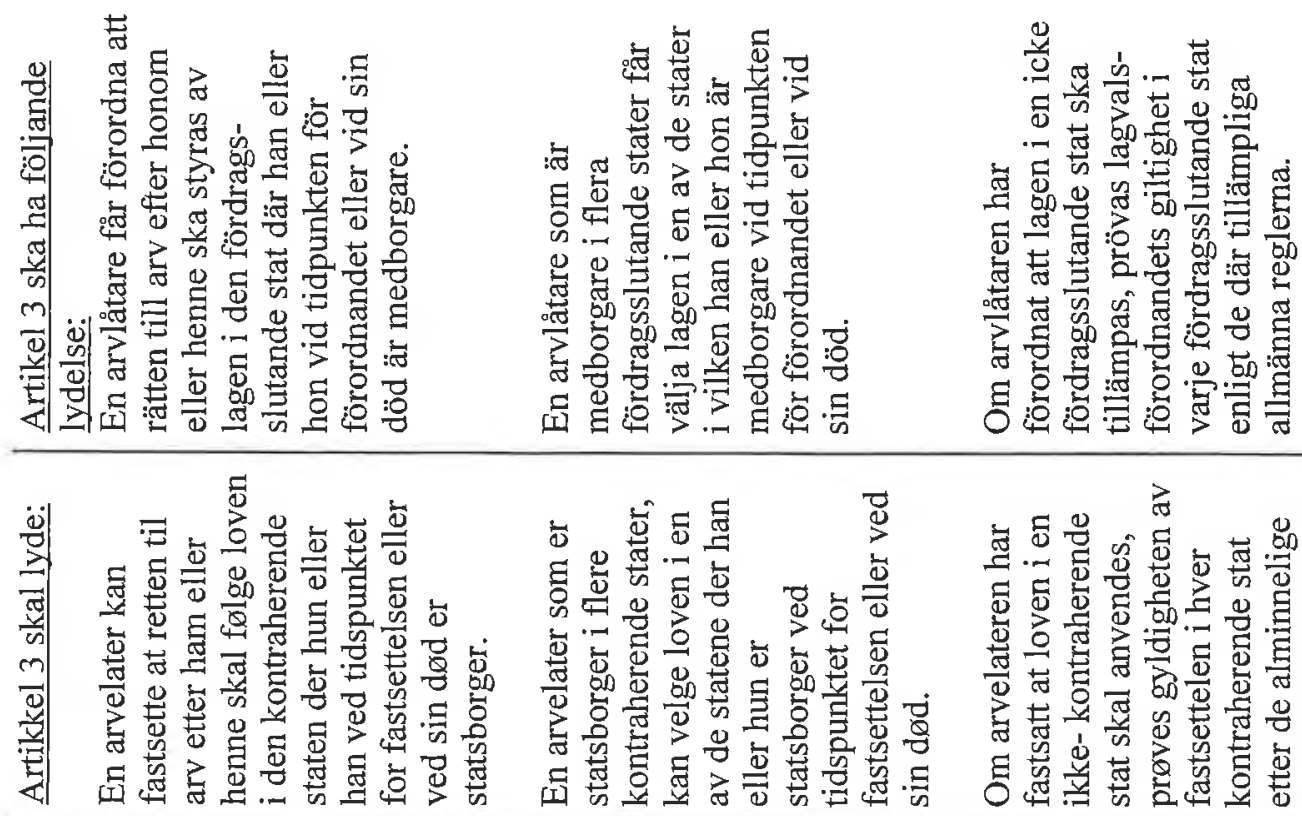

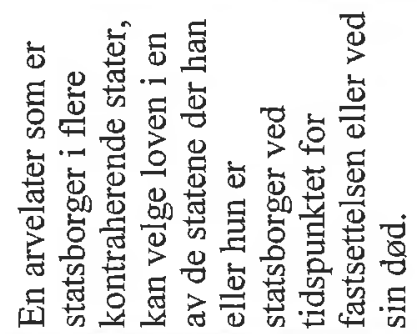

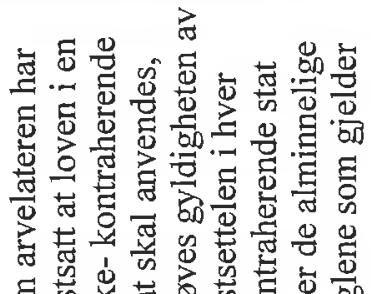

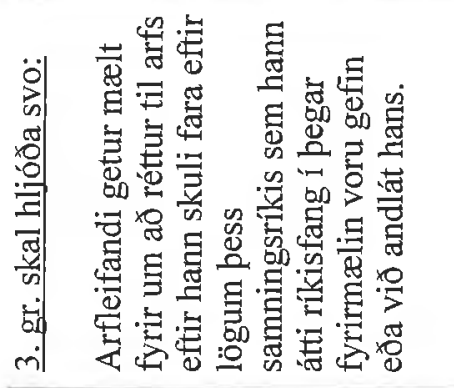

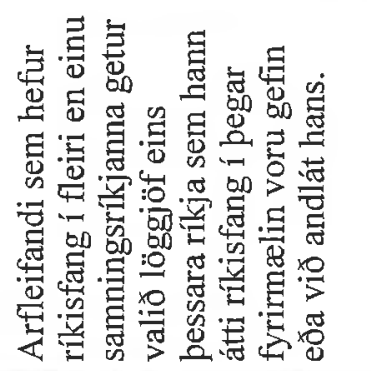

祸

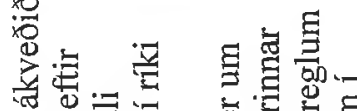

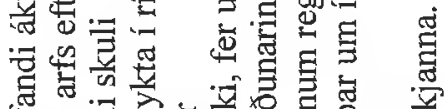

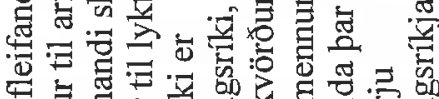

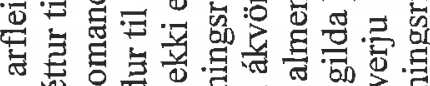

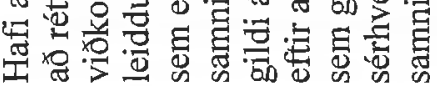

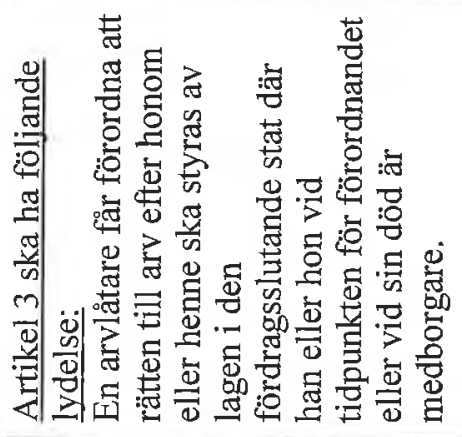

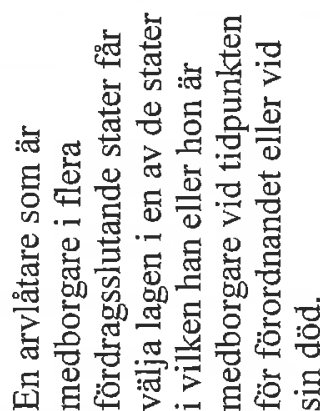

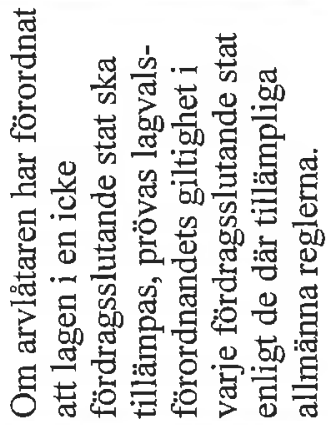

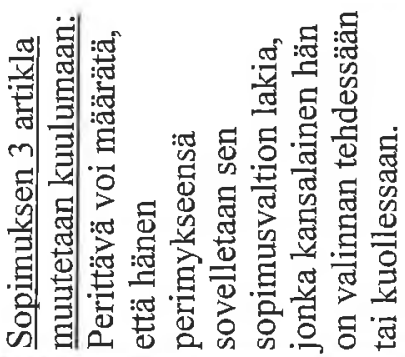

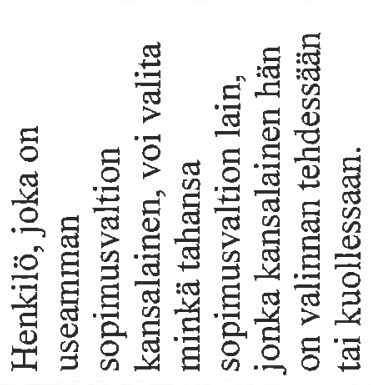

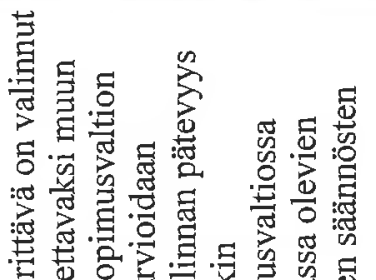

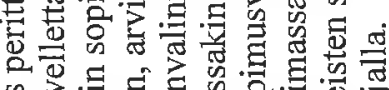

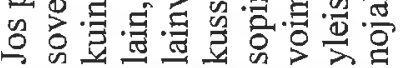

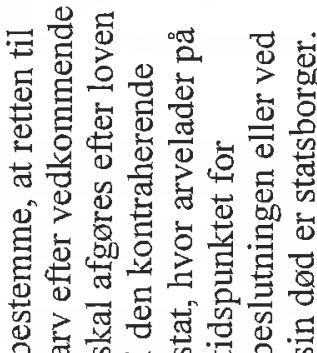

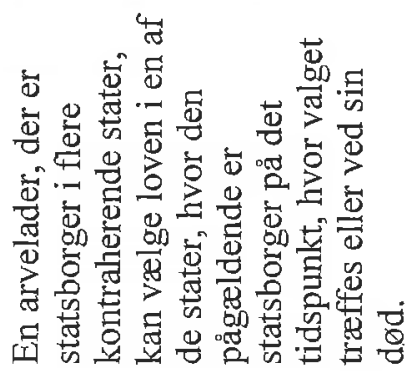

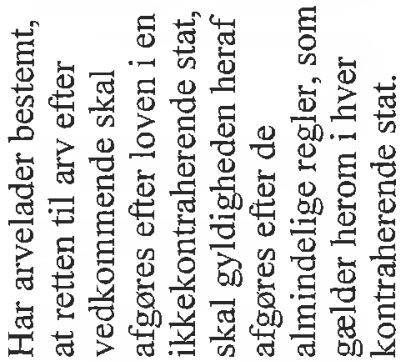




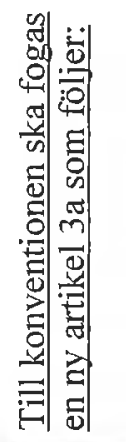

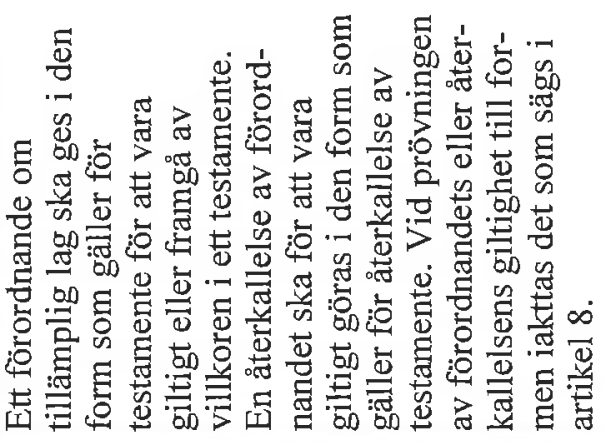

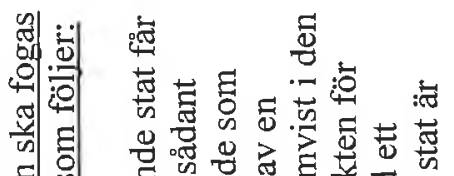

ज्ञ

.

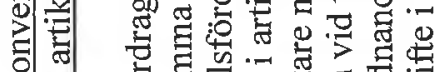

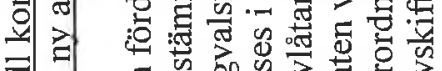

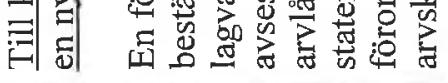

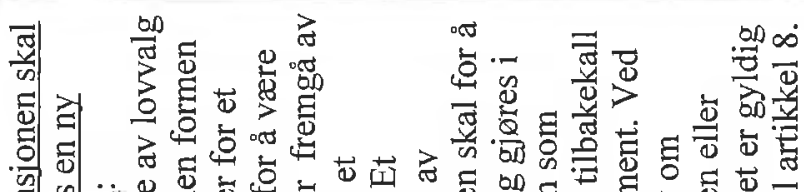

可

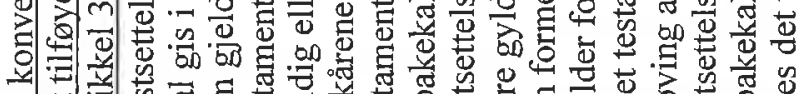

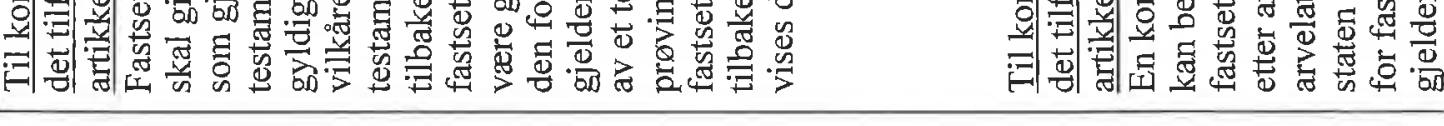

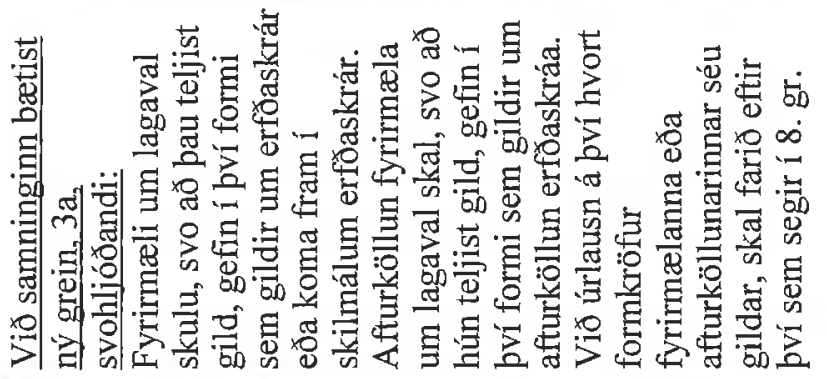

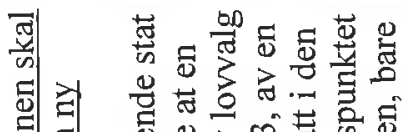

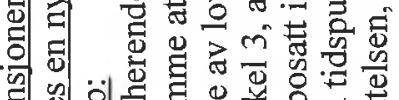

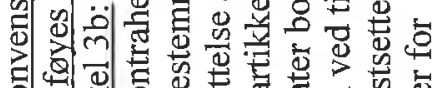

约

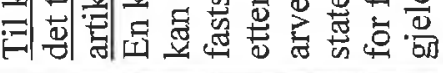

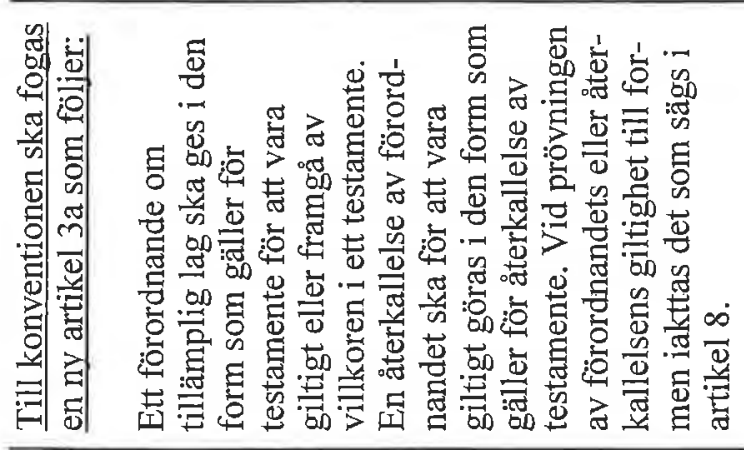

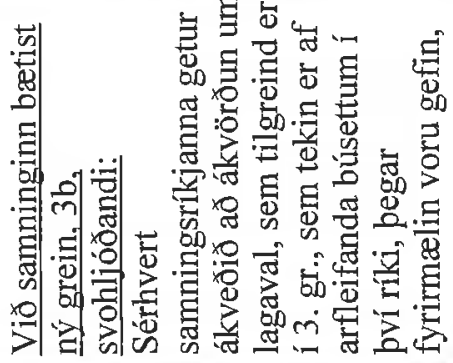

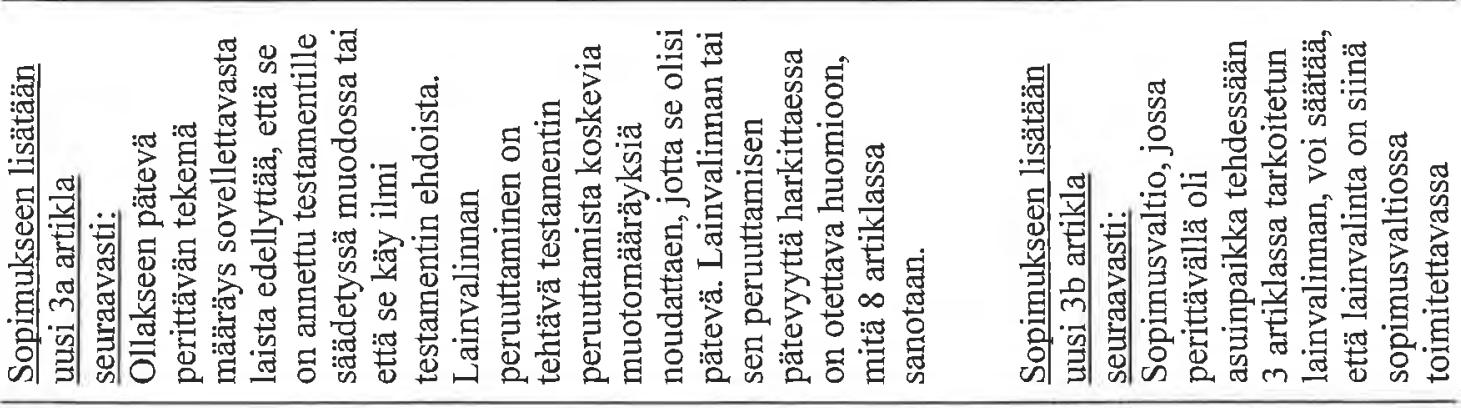

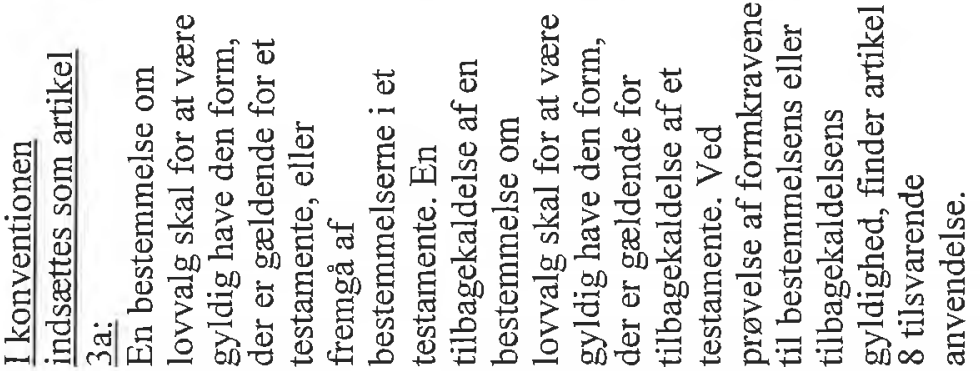

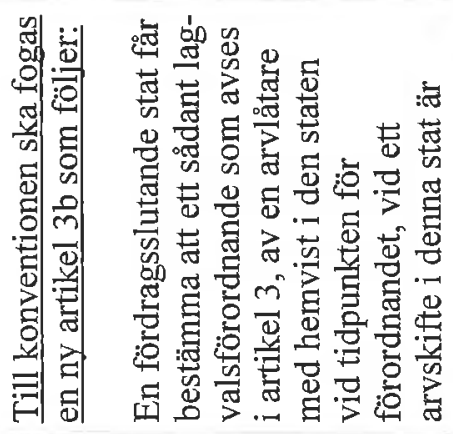



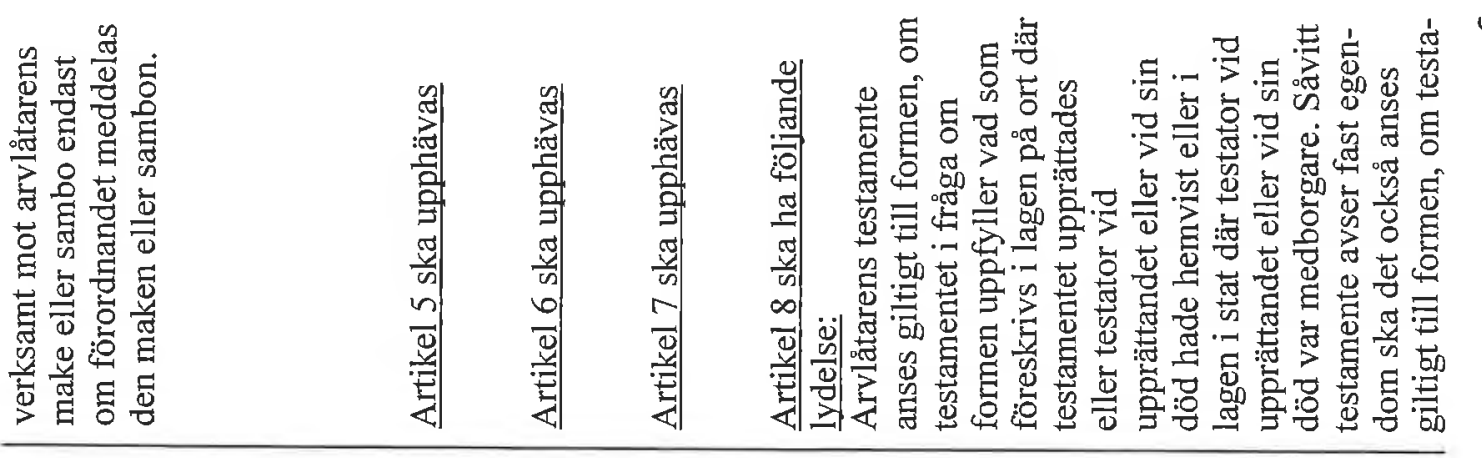

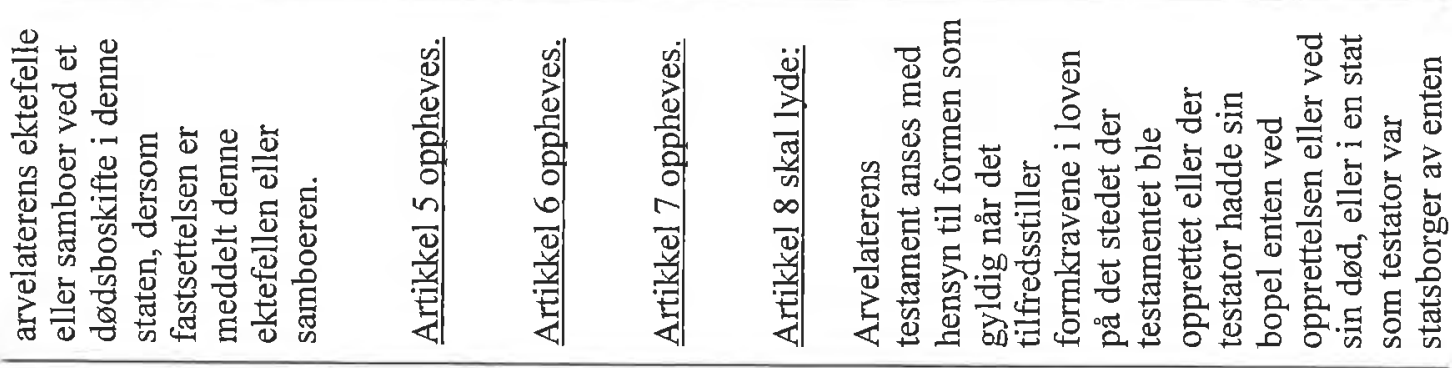

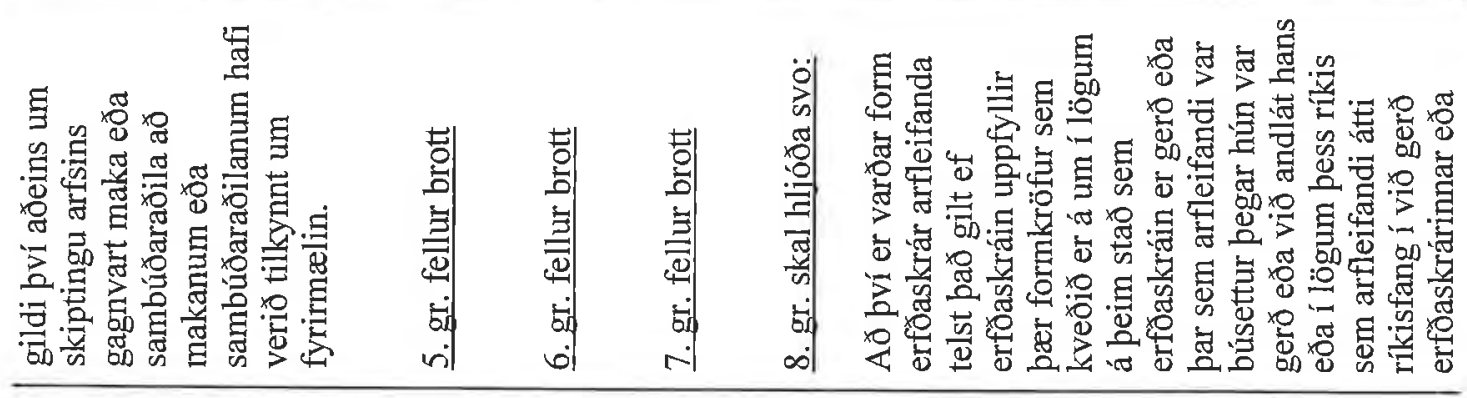

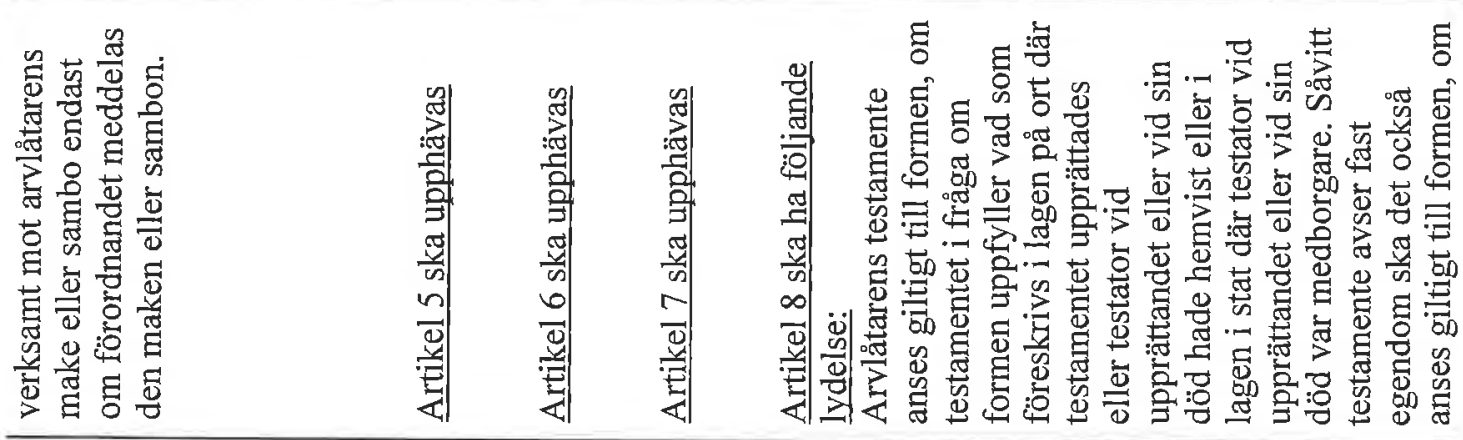

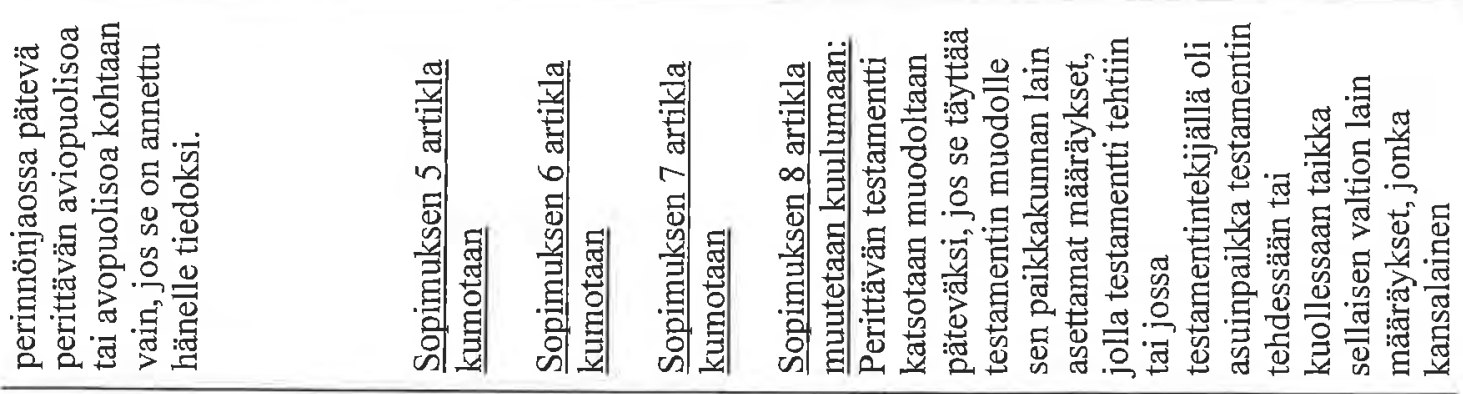

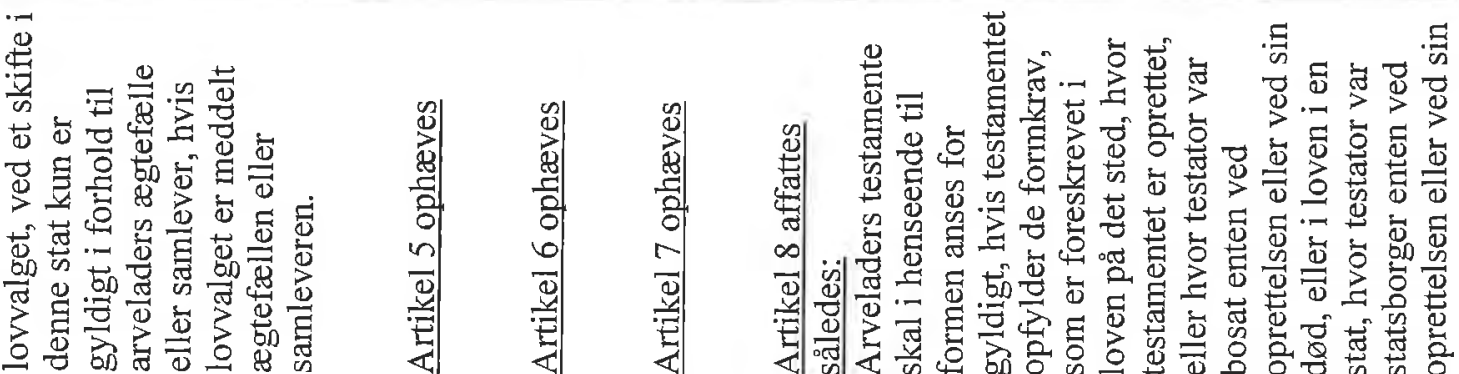




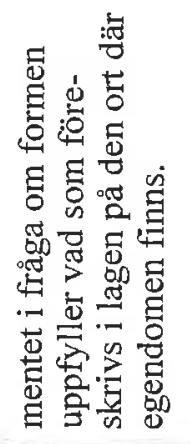

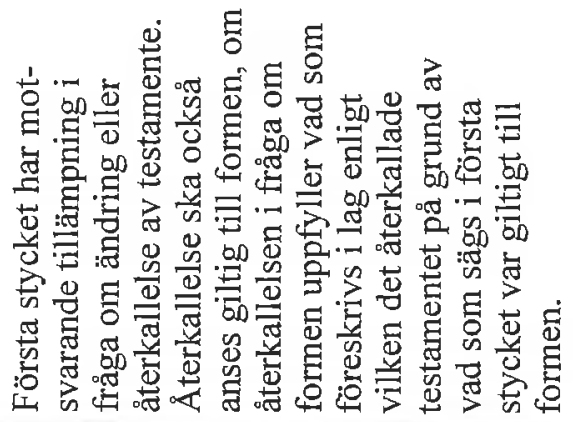

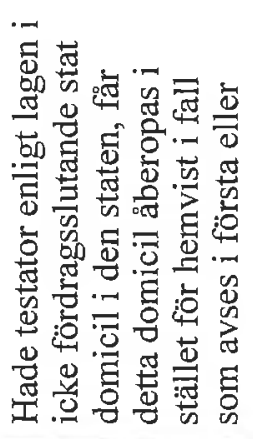

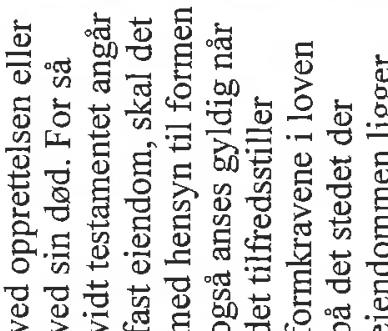

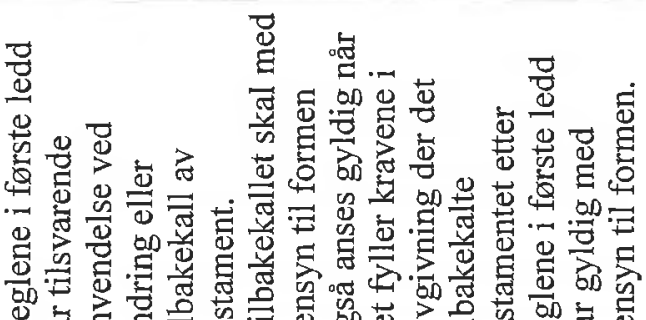

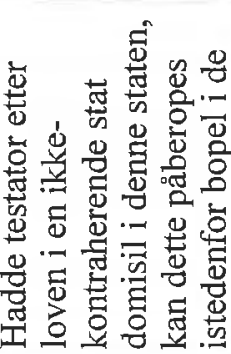

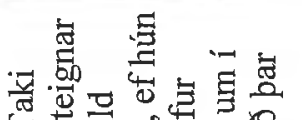

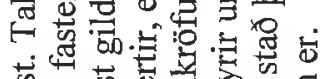

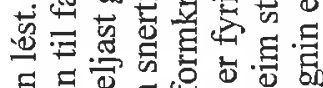

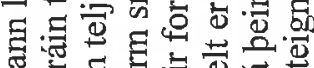

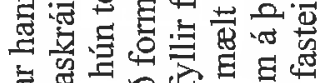

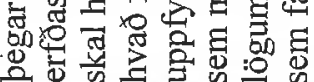

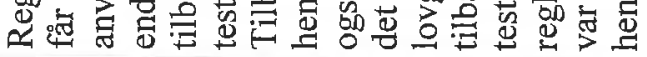

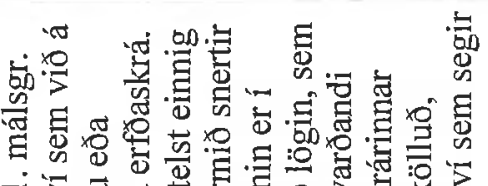

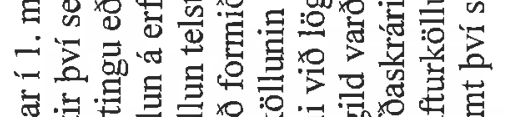

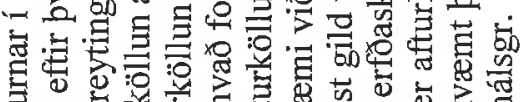

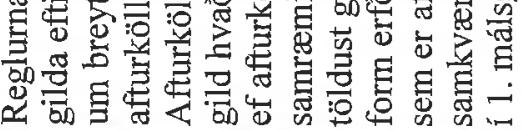

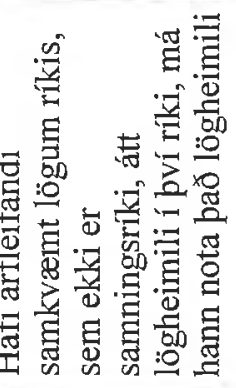

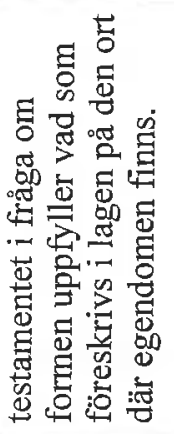

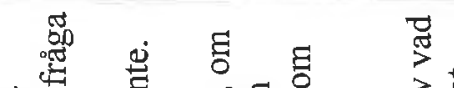

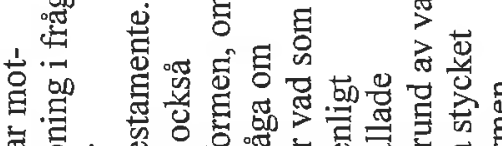

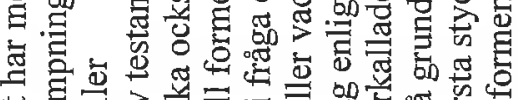

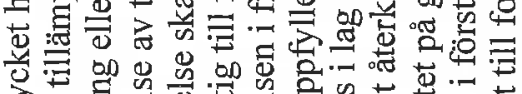

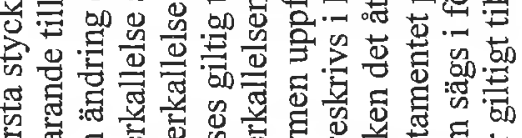

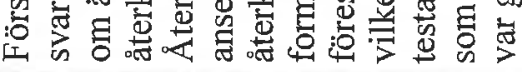

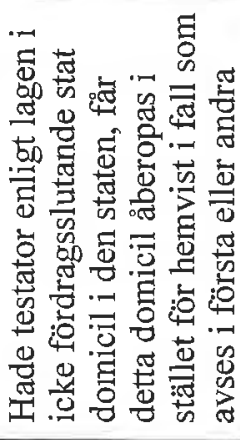

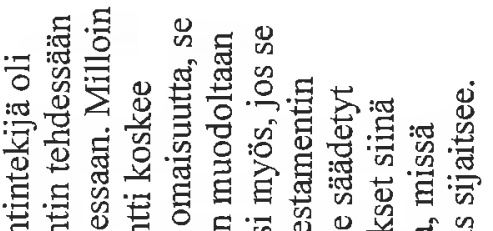

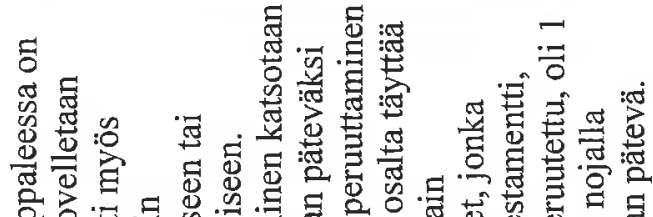

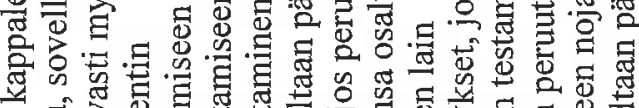

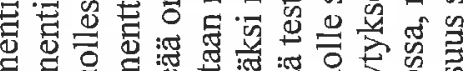

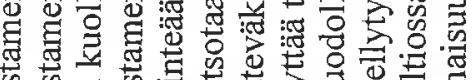

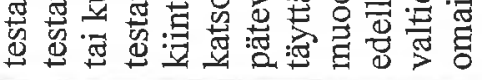

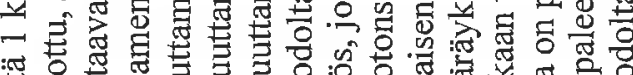

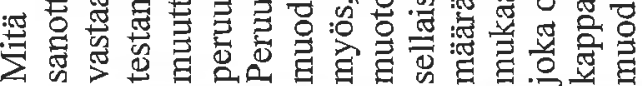

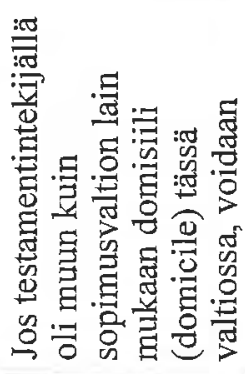

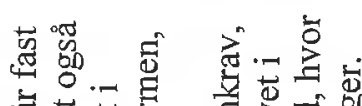

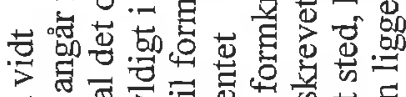

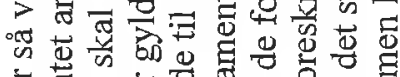

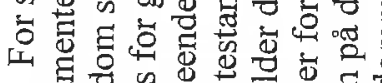

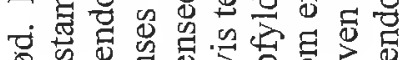

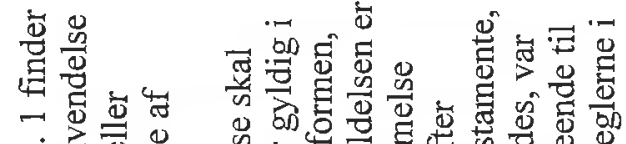

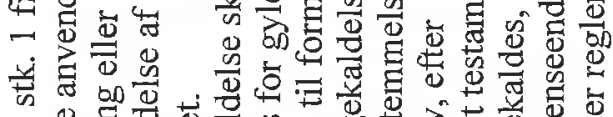

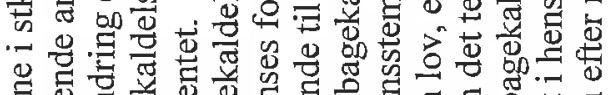

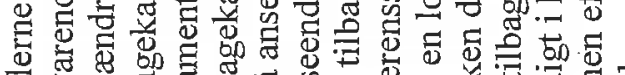

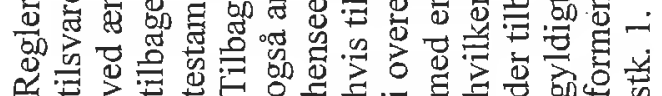

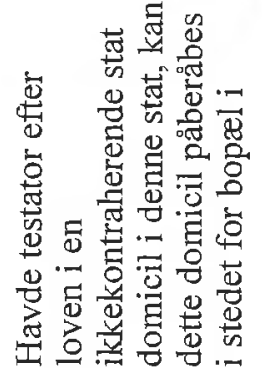



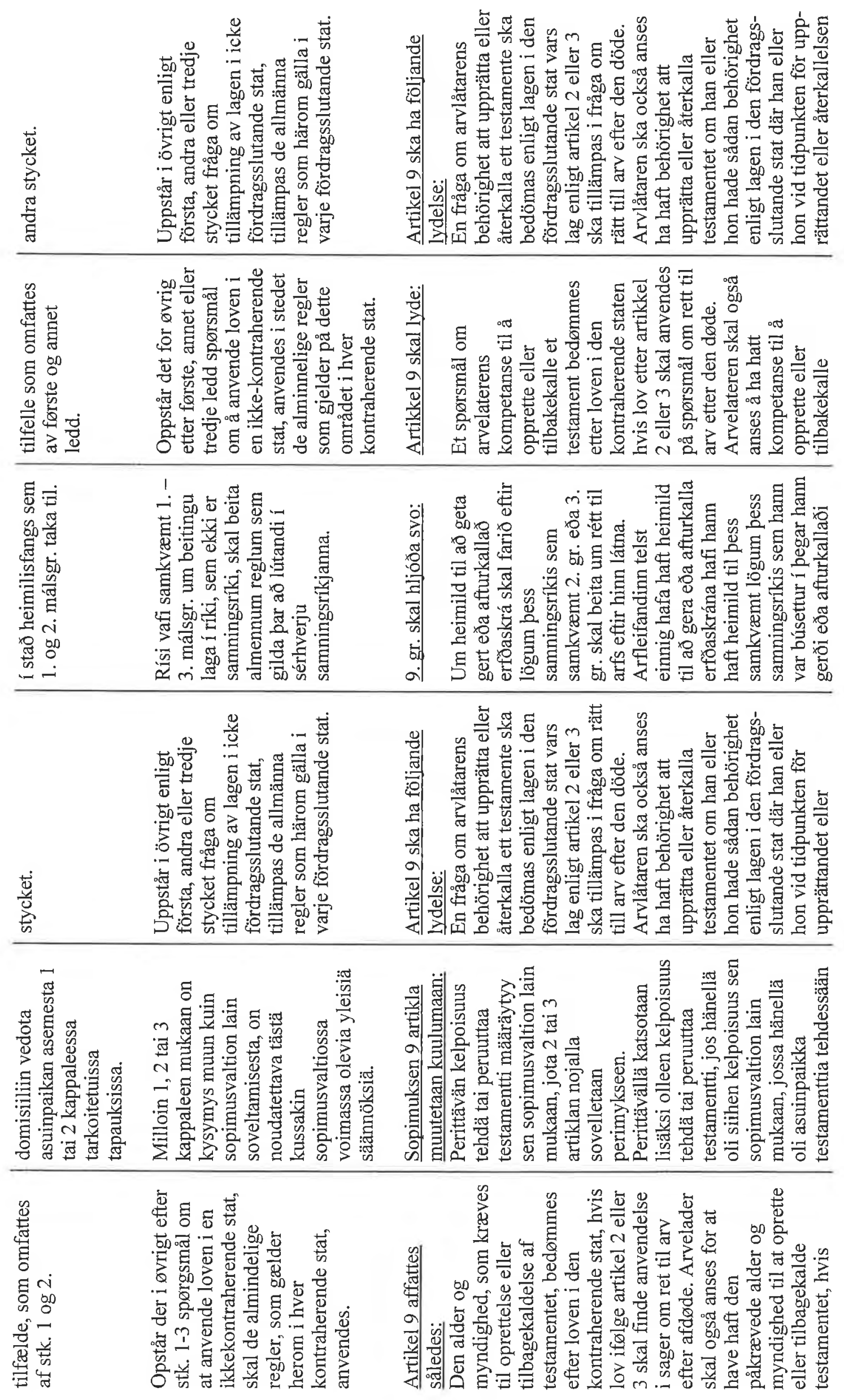


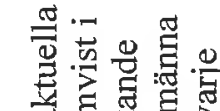

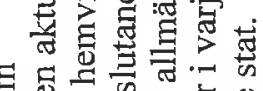

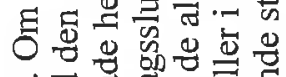

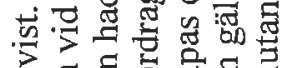

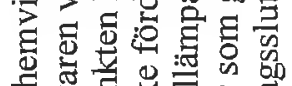

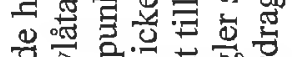

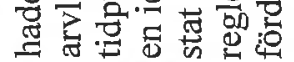

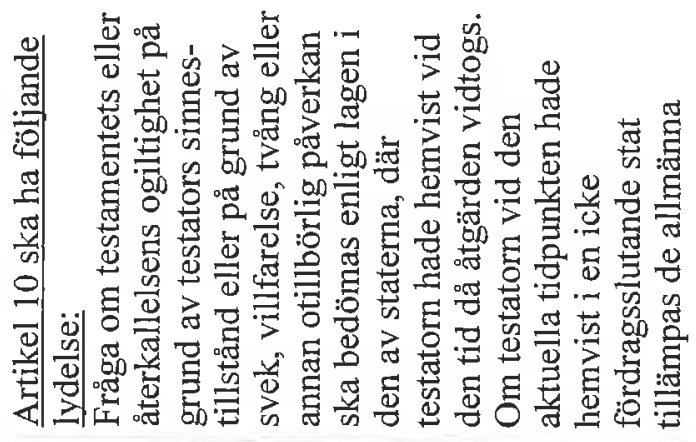

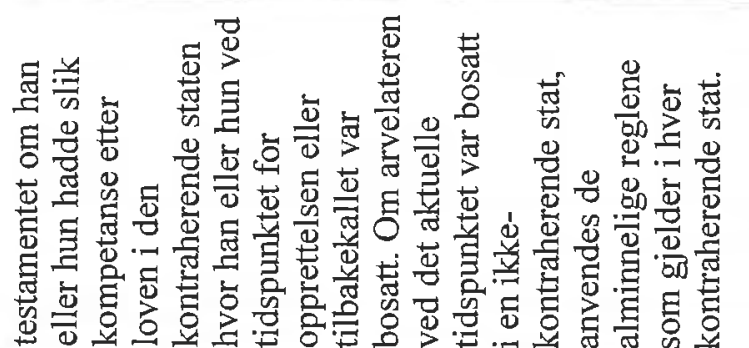

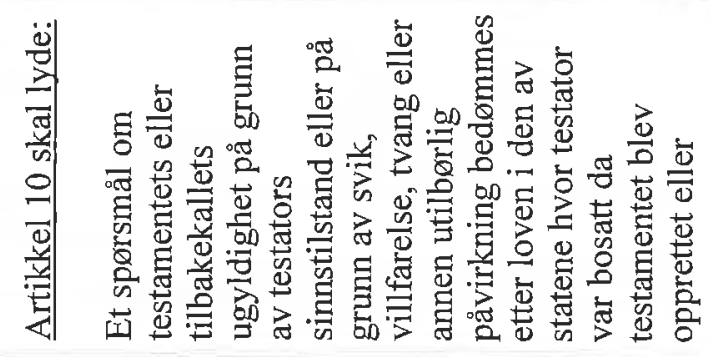

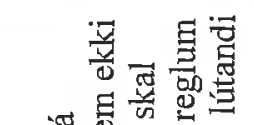

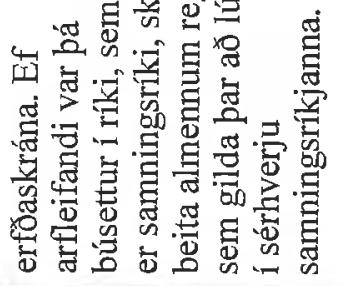

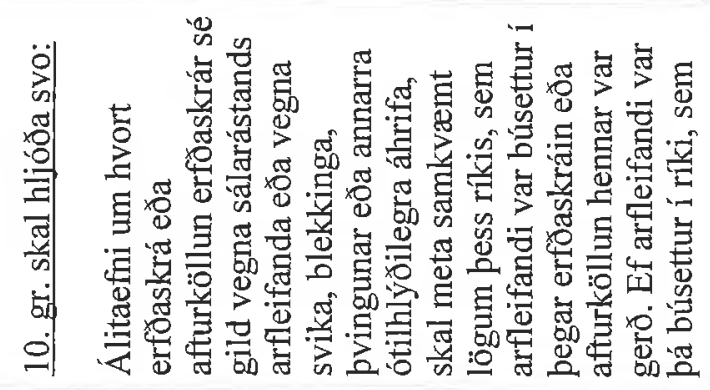

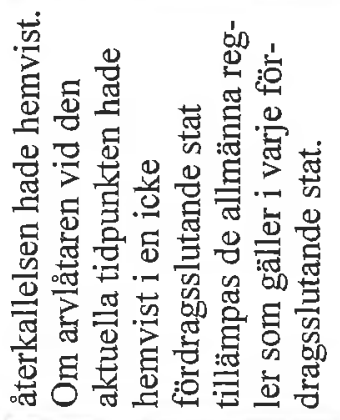

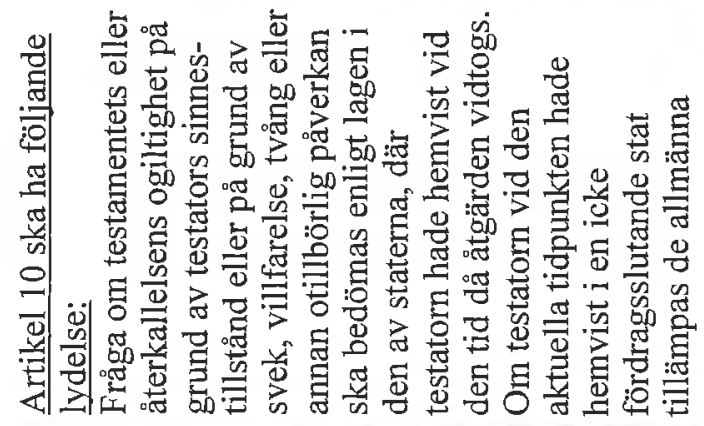

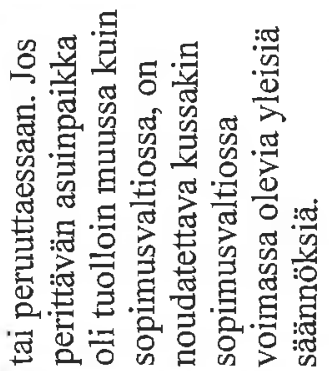

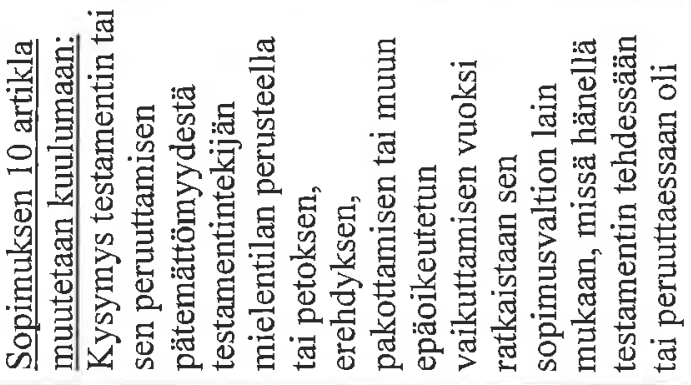

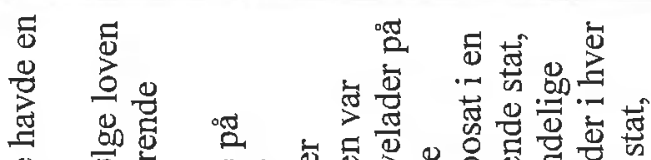

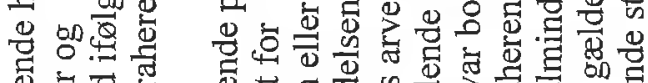

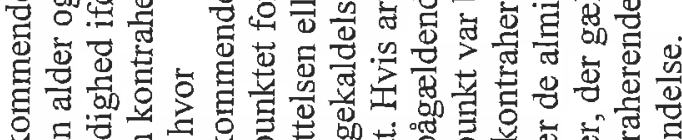

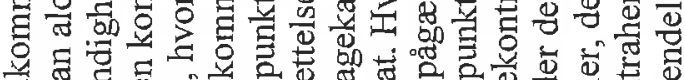




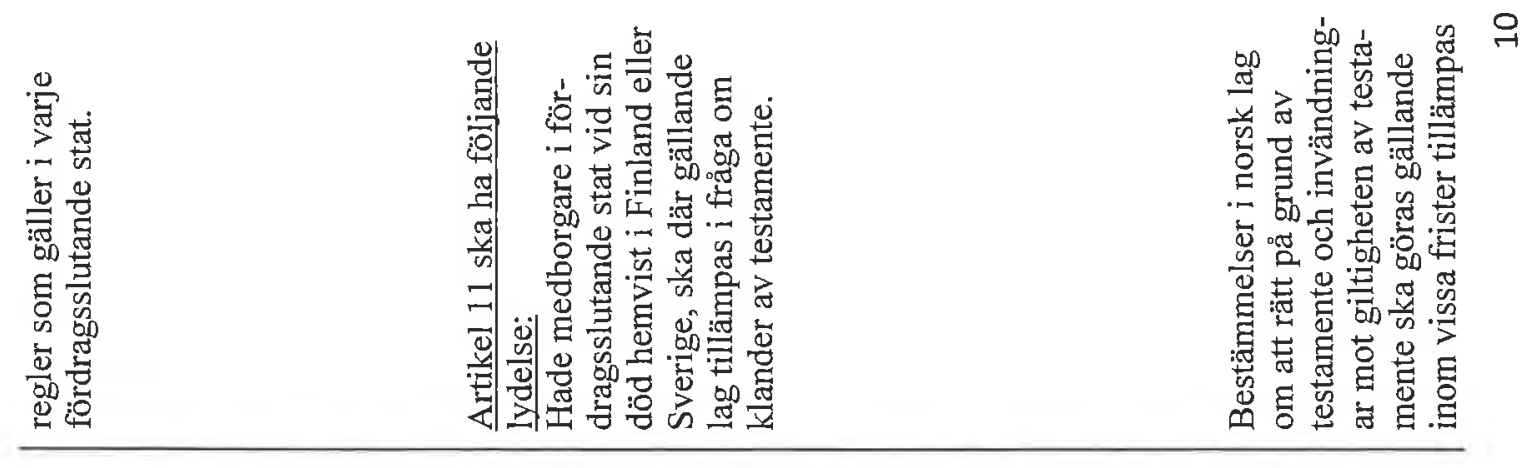

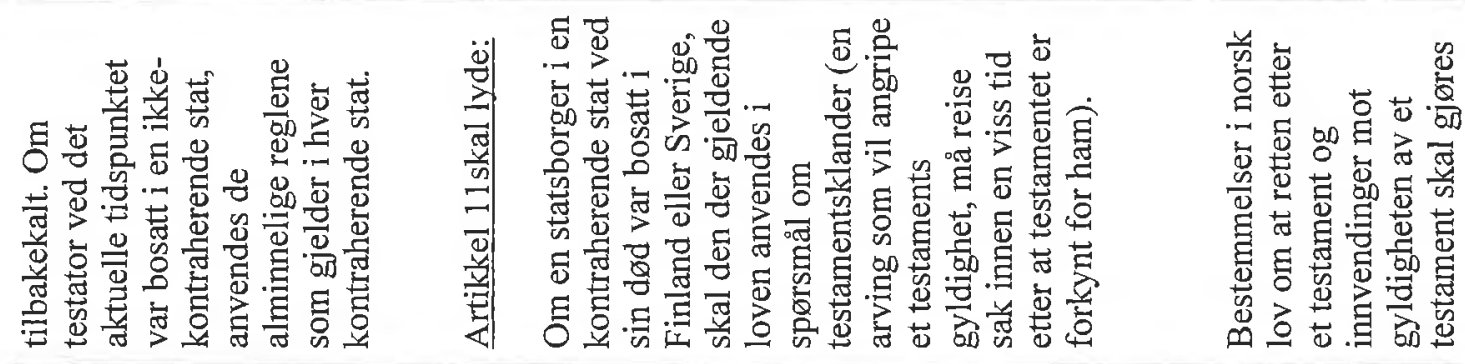

\begin{tabular}{|c|c|c|c|}
\hline 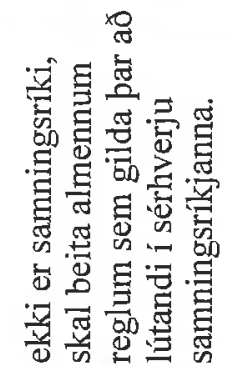 & 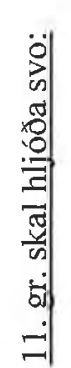 & 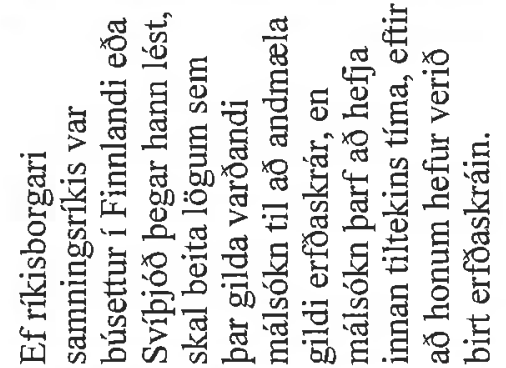 & 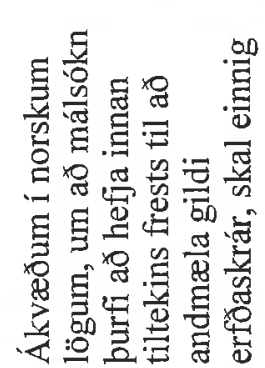 \\
\hline
\end{tabular}

\begin{tabular}{|c|c|c|}
\hline 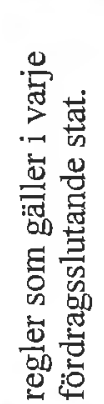 & 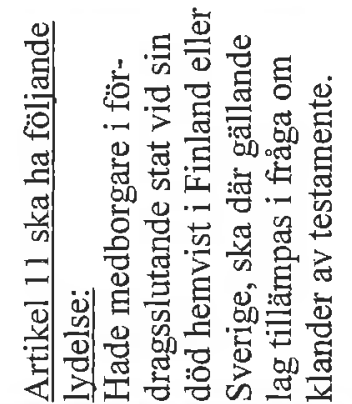 & 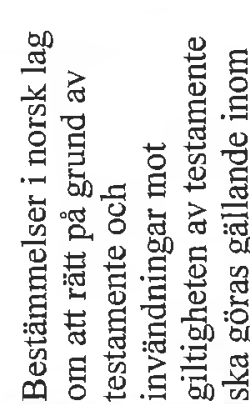 \\
\hline
\end{tabular}

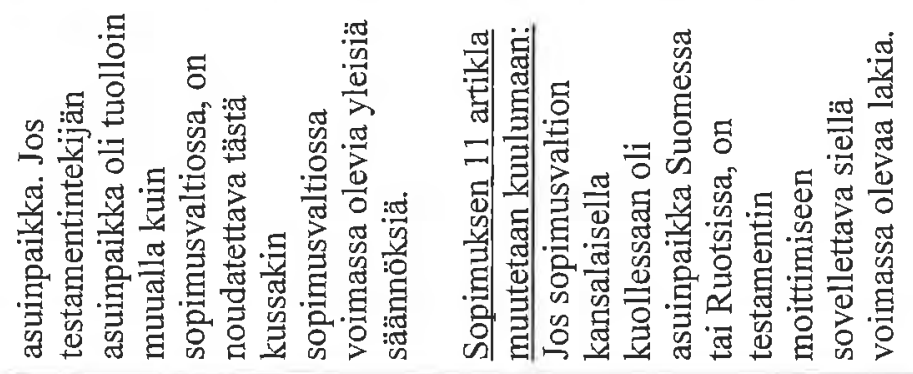
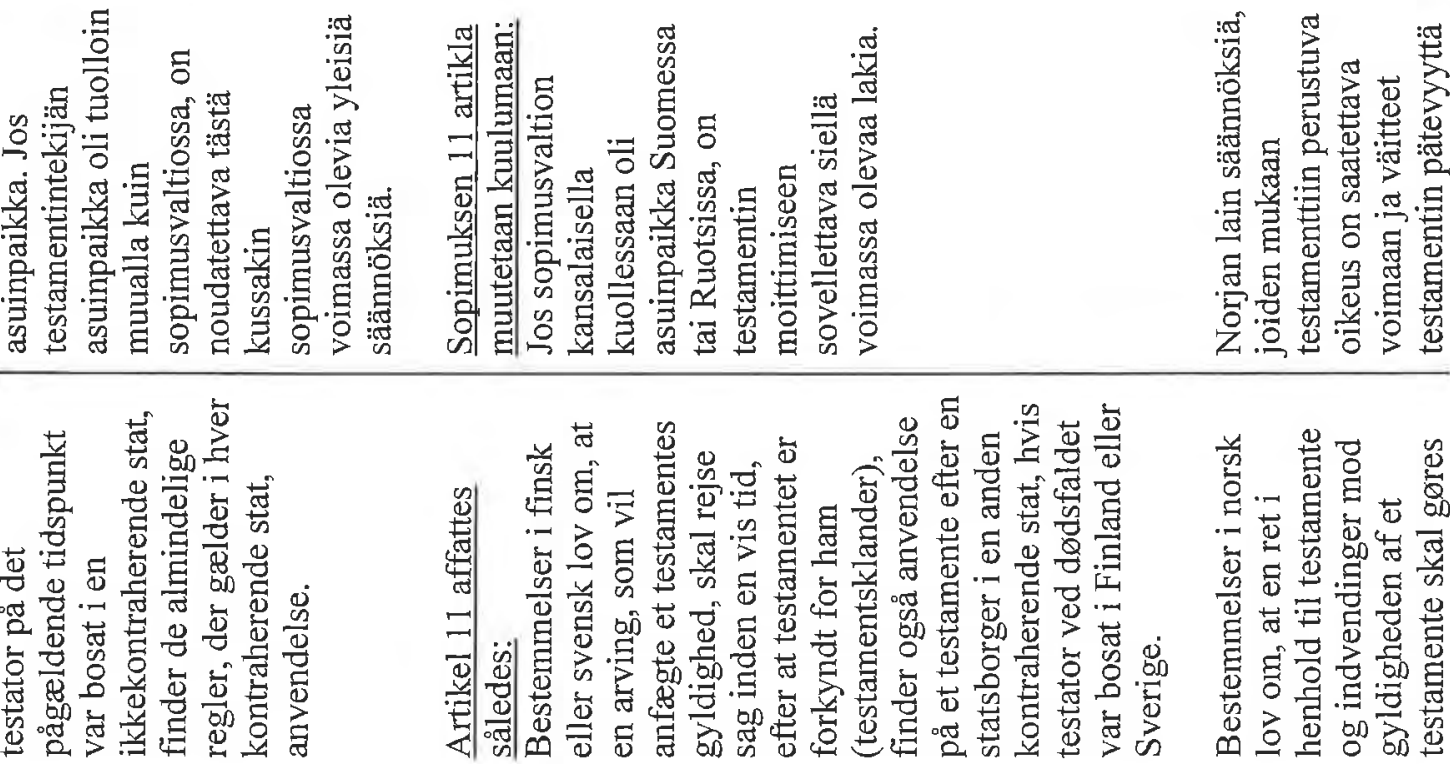

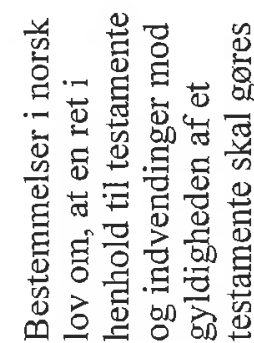




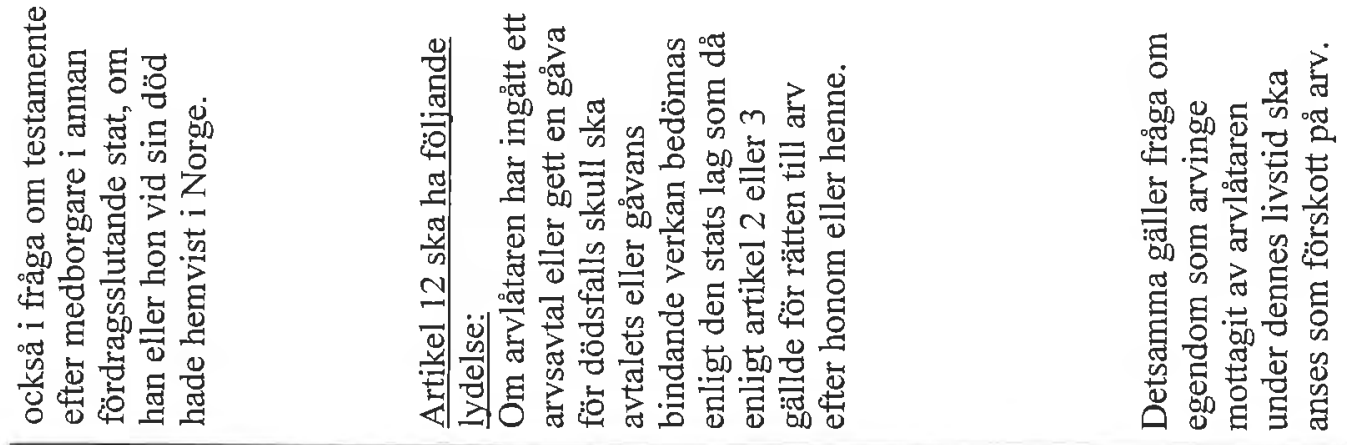

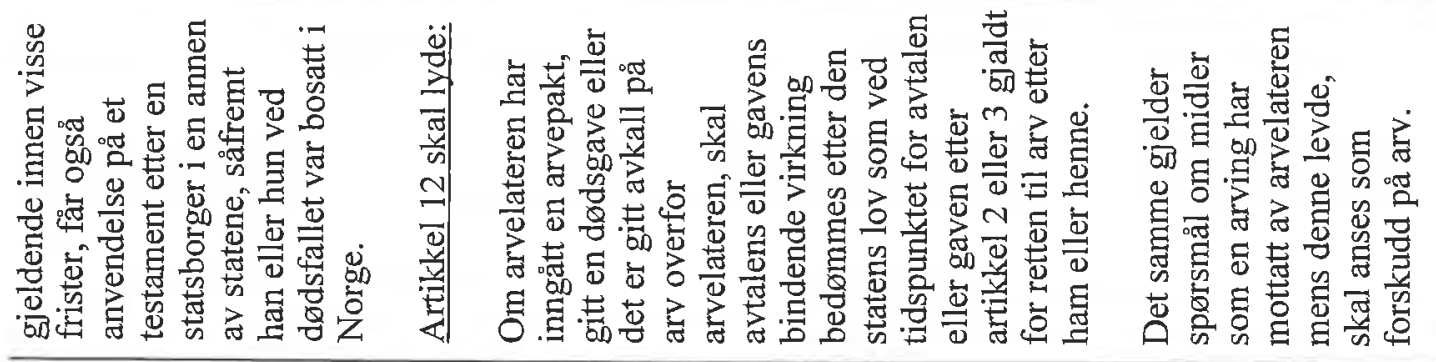

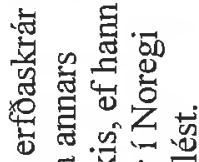

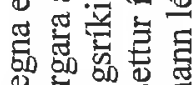

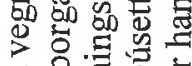

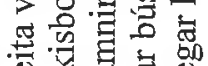

造密范造

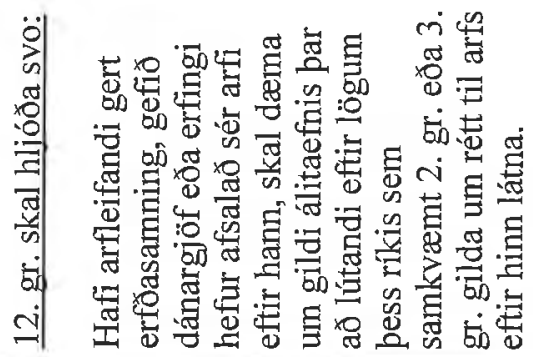

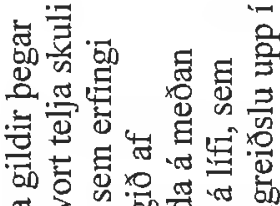

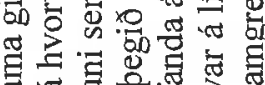

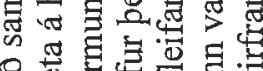

密焉范

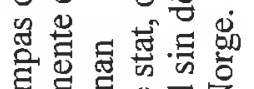

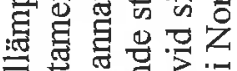

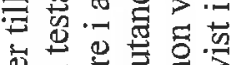

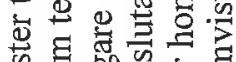

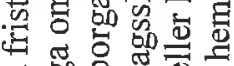

要造要

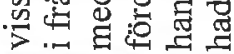

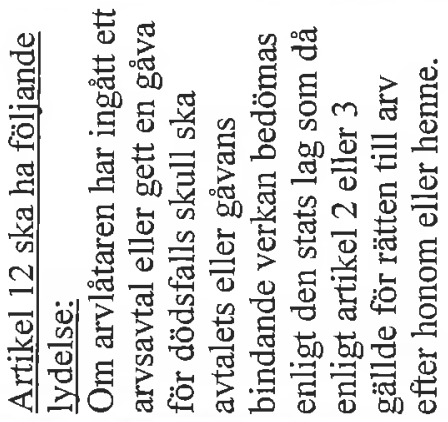

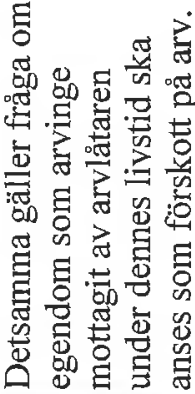

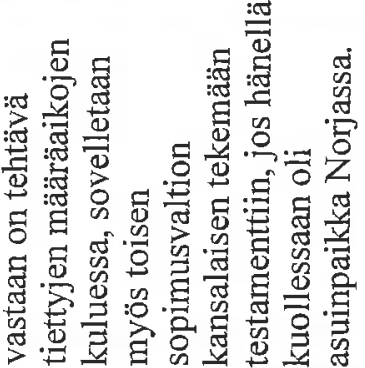

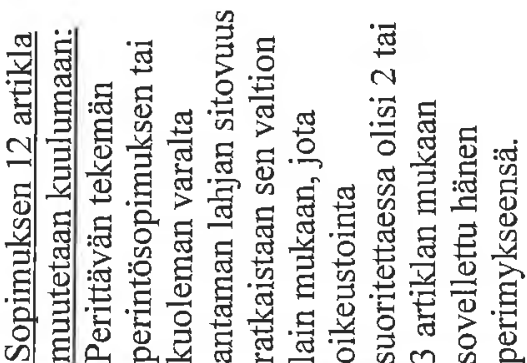

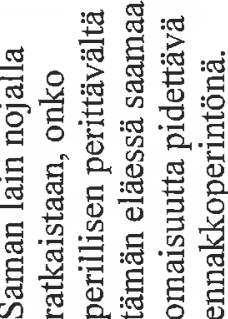

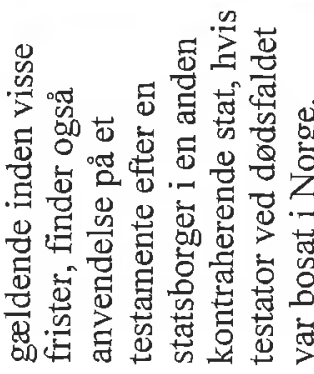
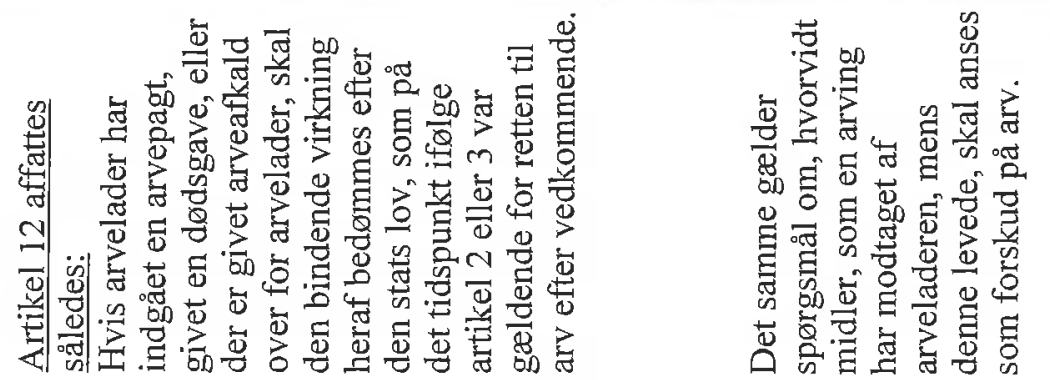


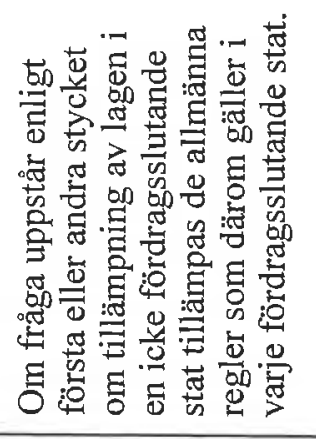

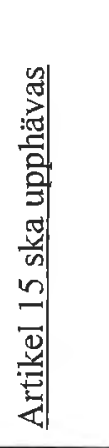

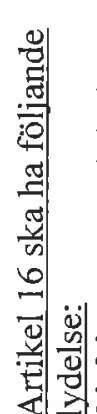

裳

.

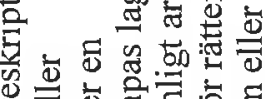

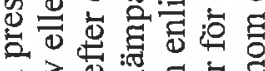

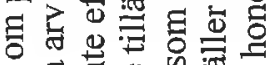

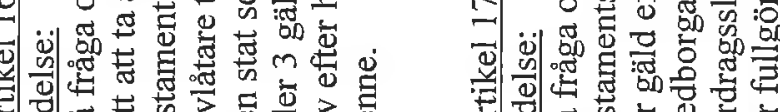

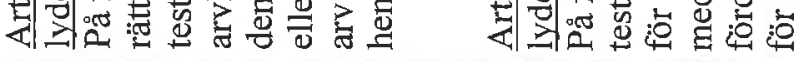

政

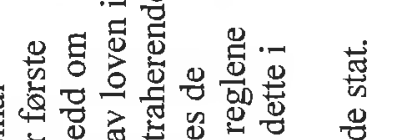

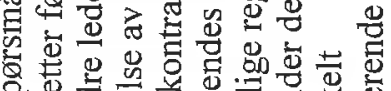

की

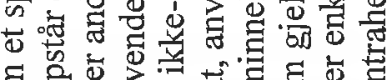

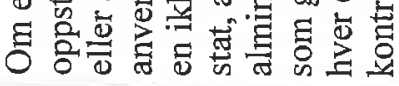

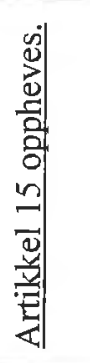

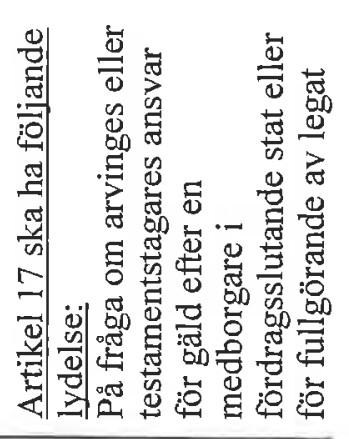

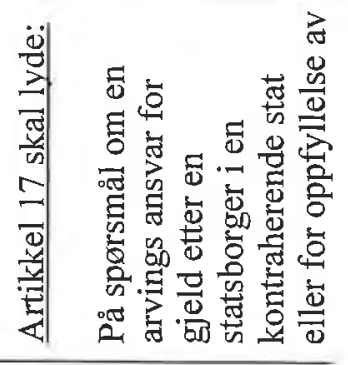

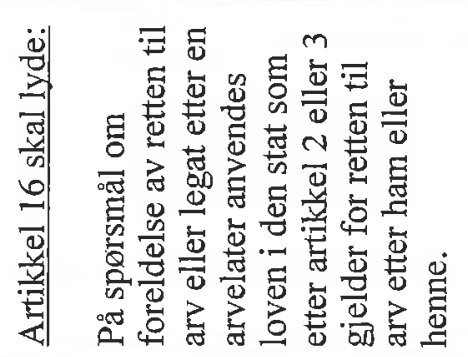

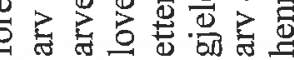

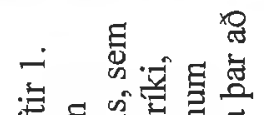

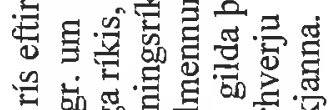

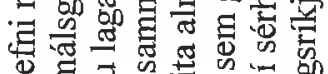

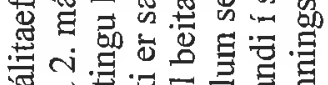

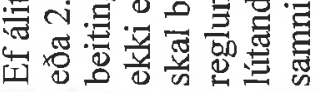
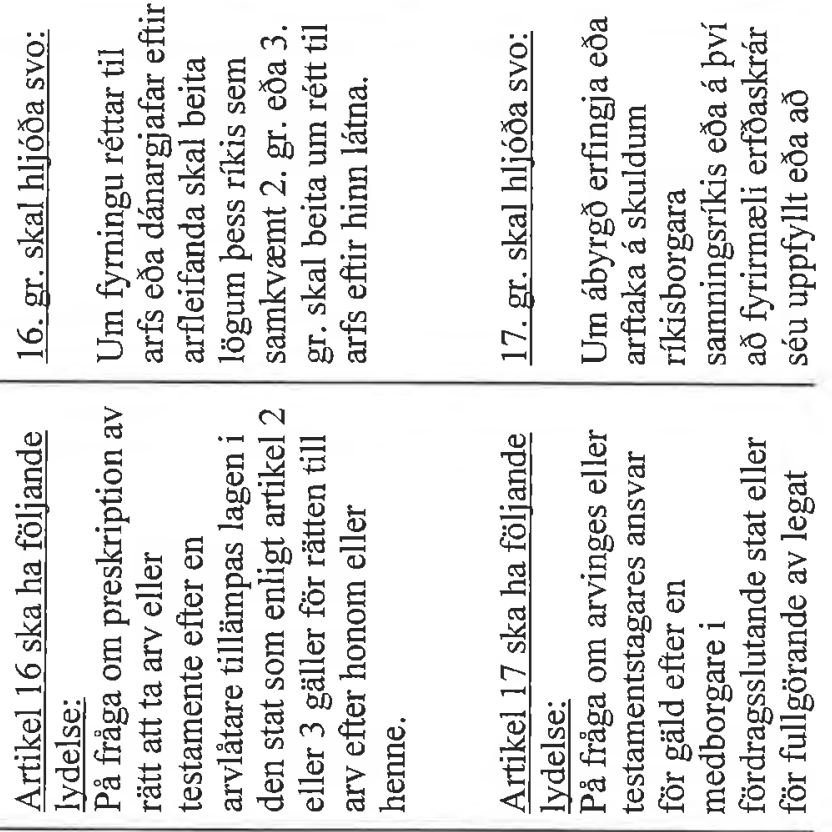

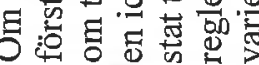

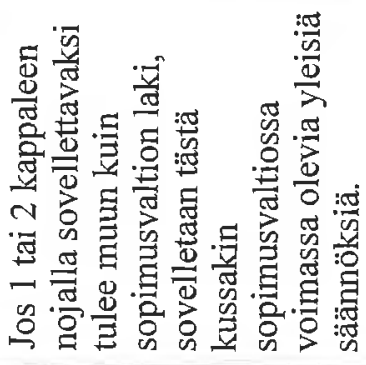

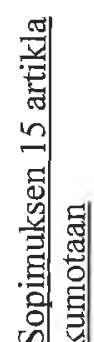

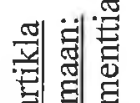

:

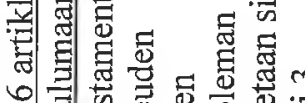

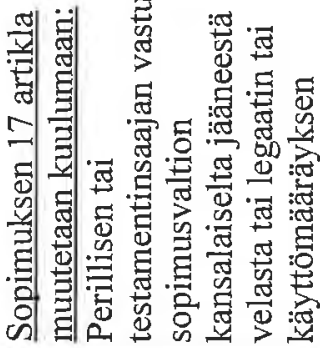

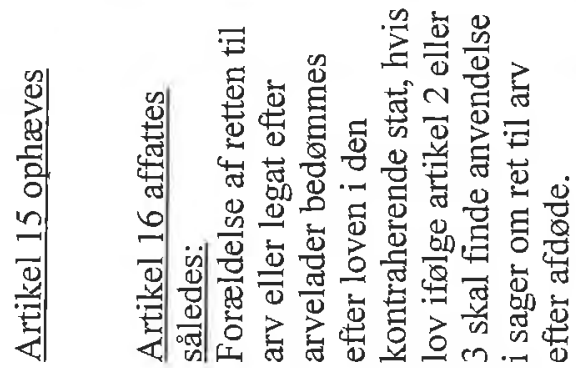



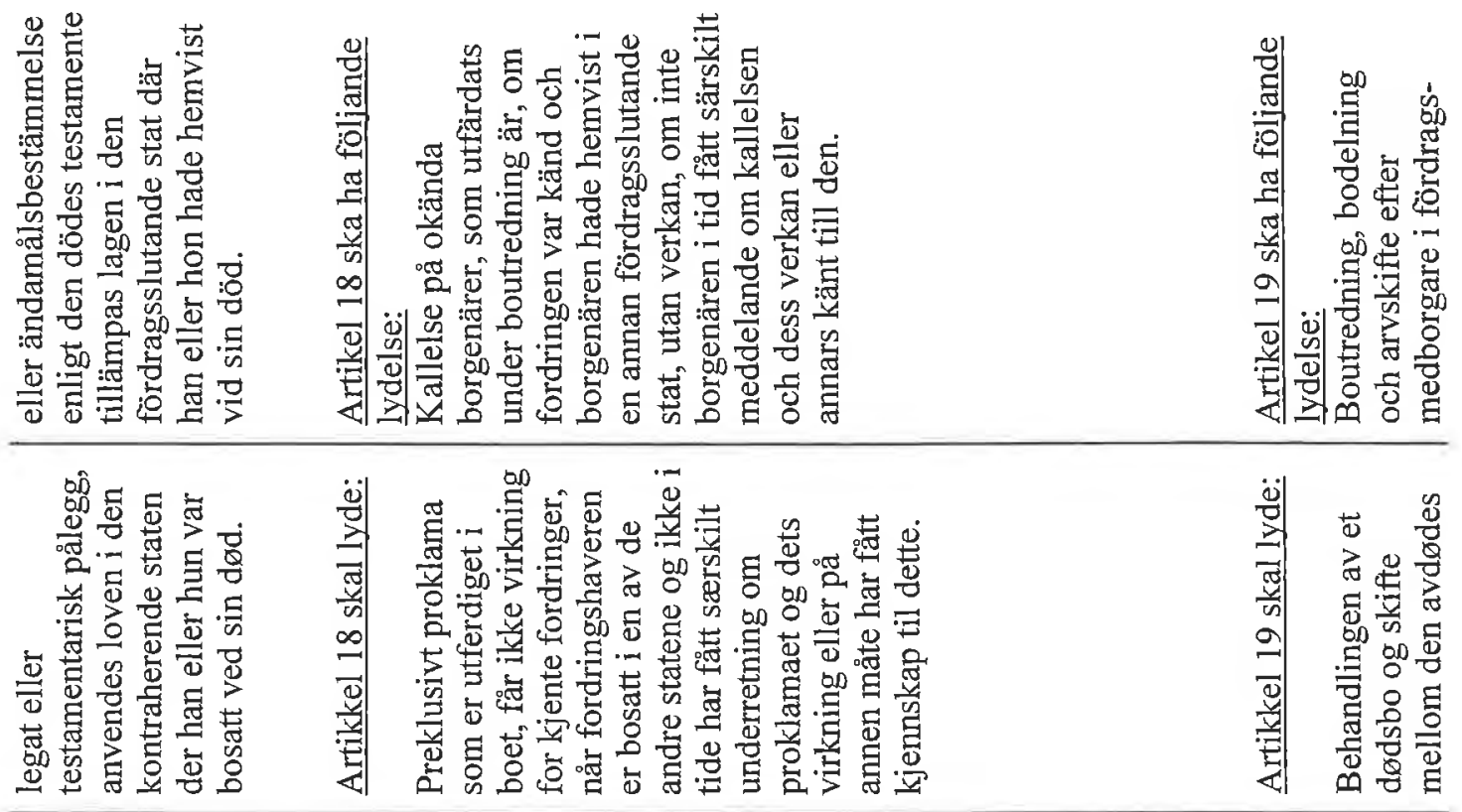

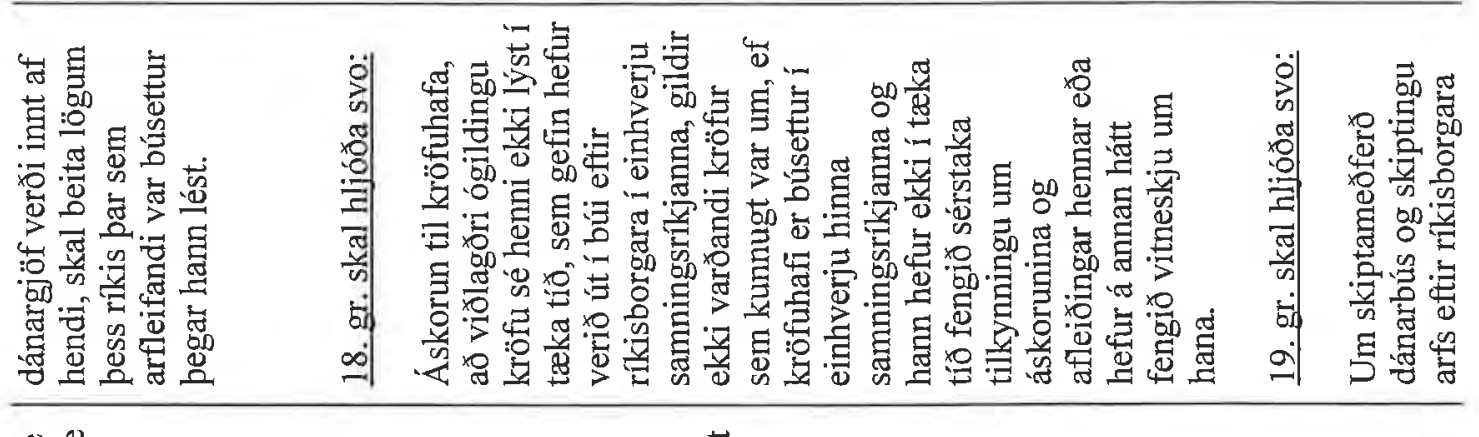

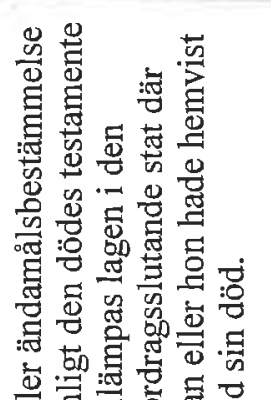

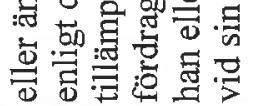
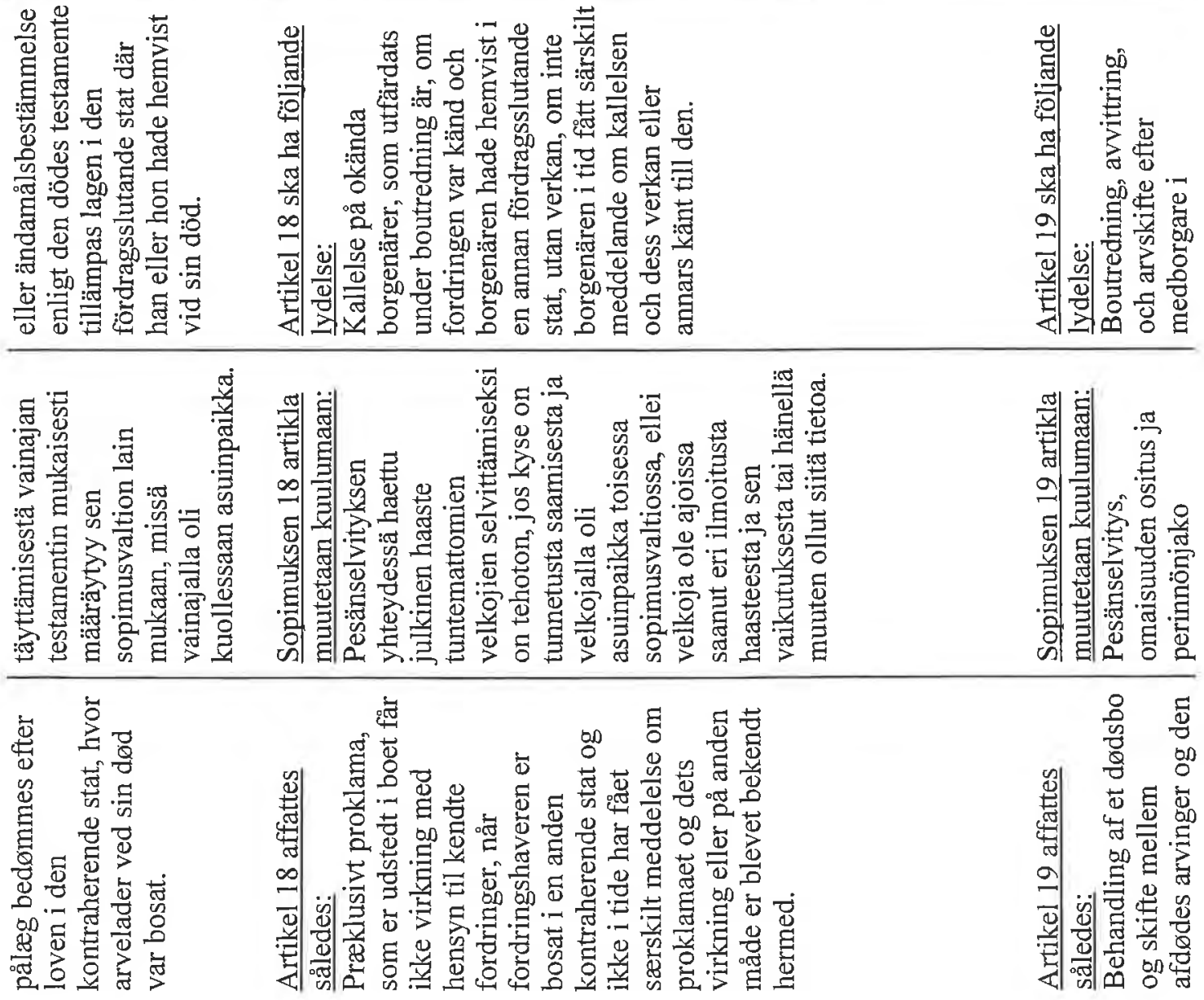


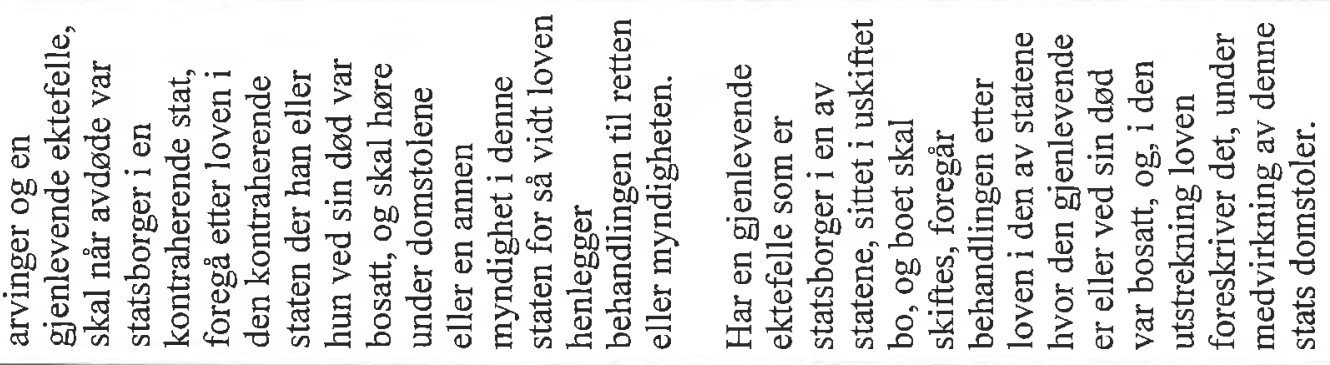

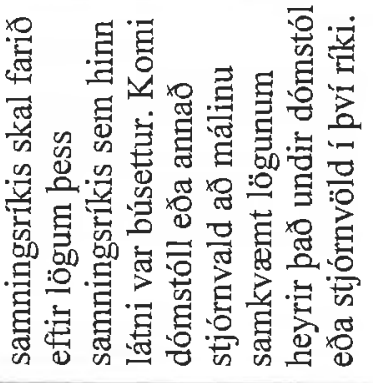

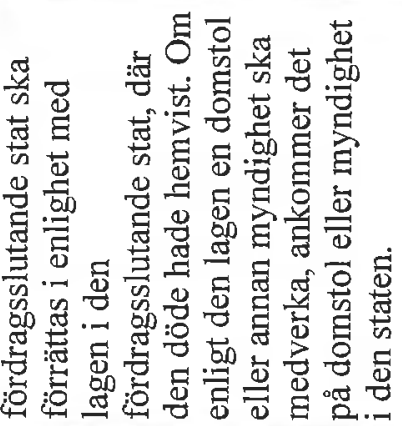

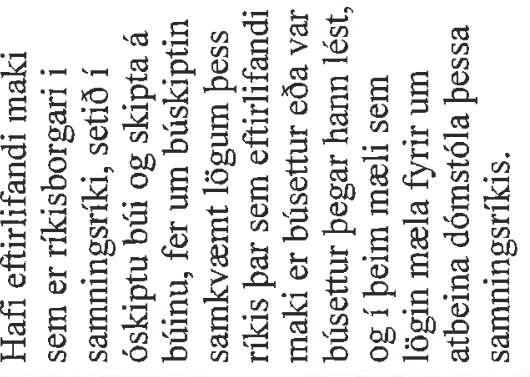

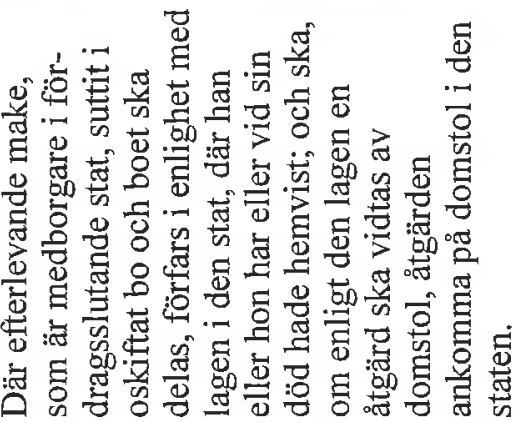

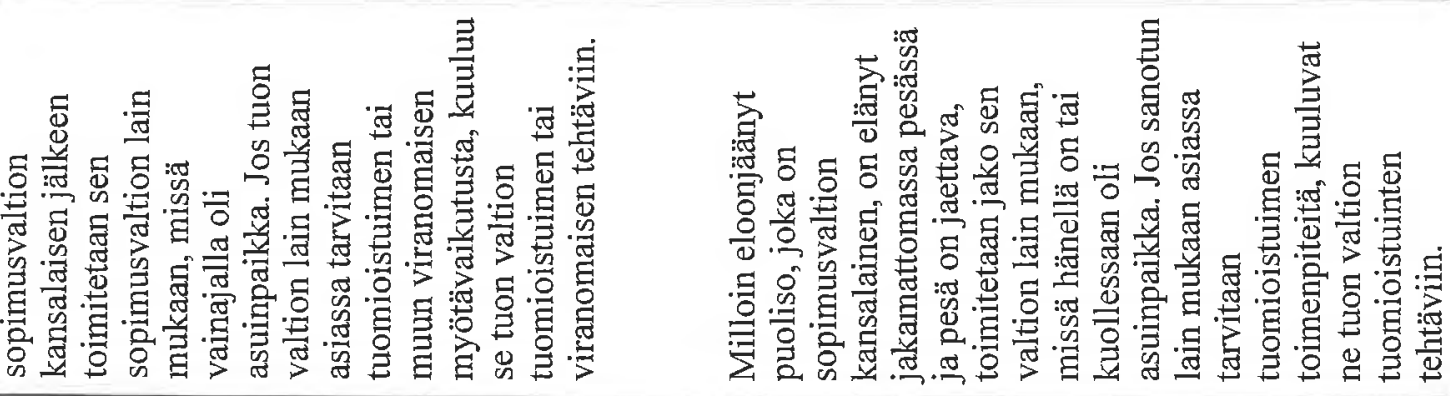
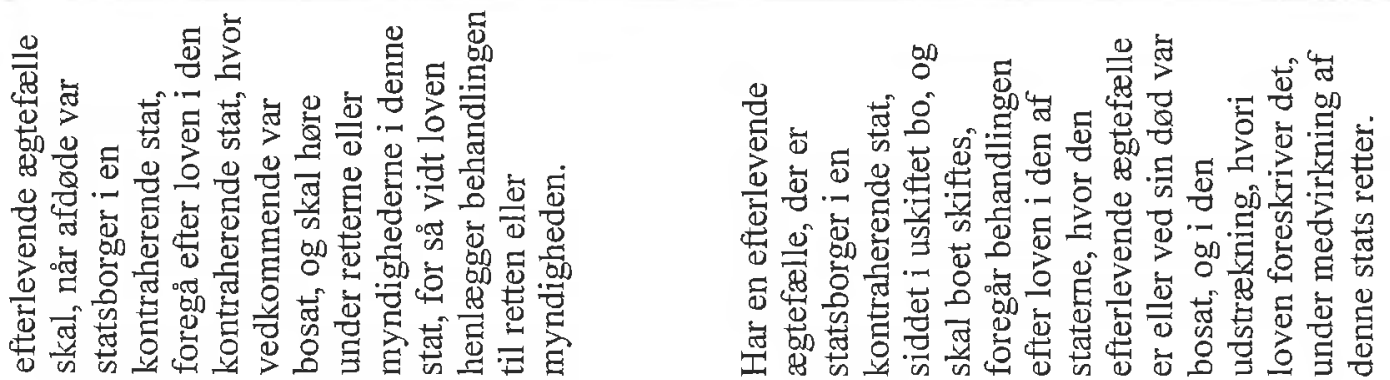


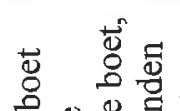

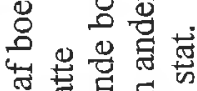

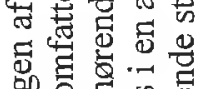
吅

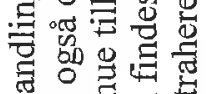

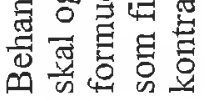




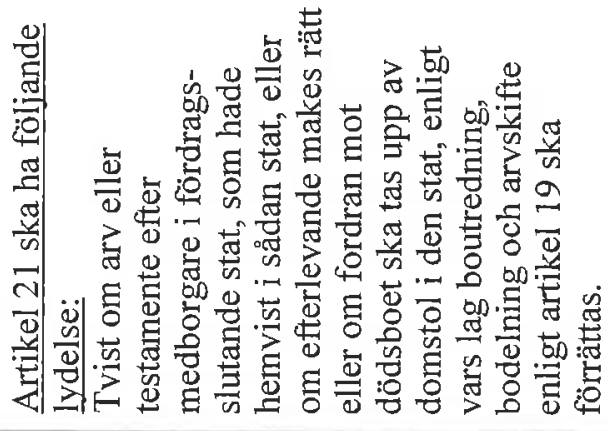

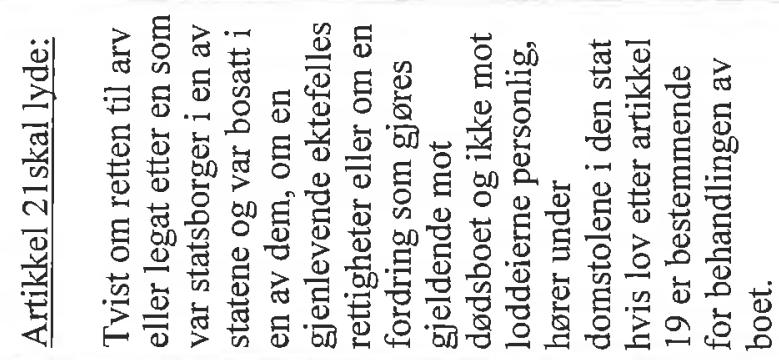

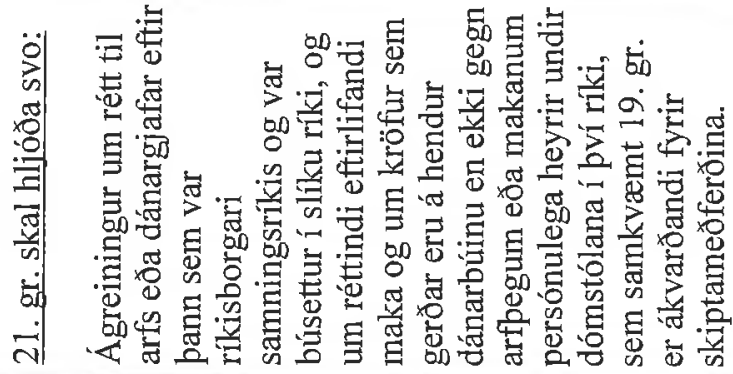

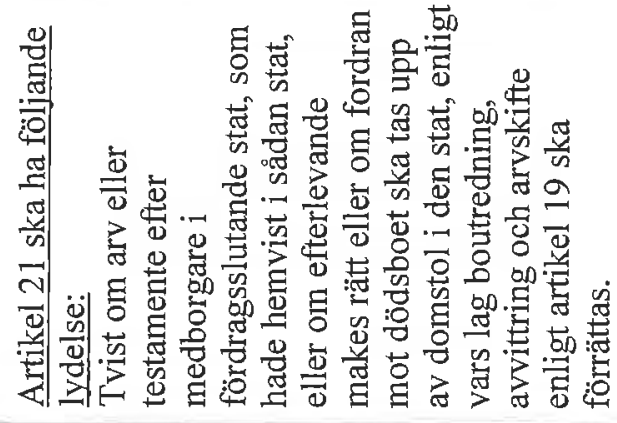

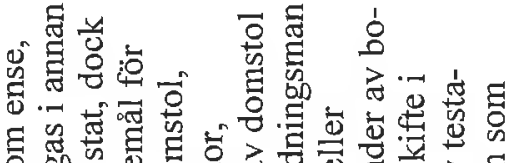

ह气

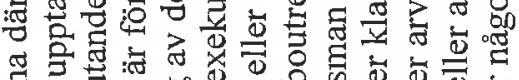
它 ton

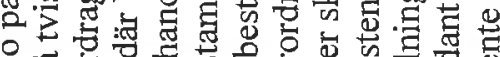

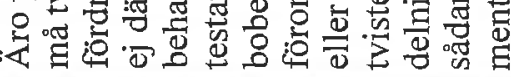

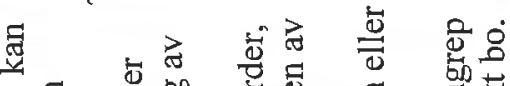

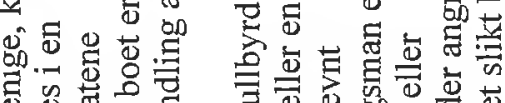

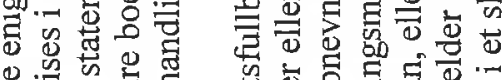

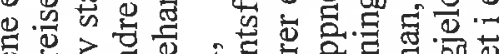

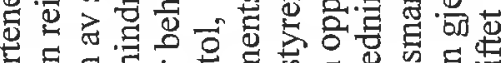

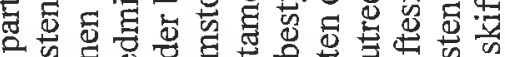

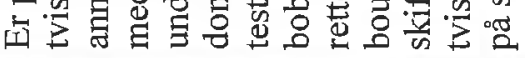

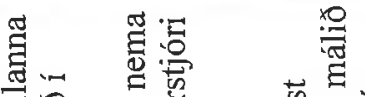

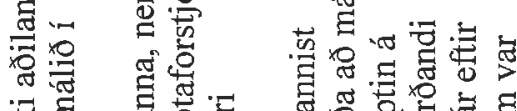

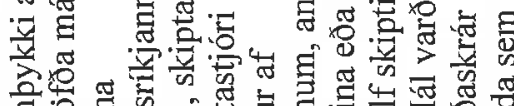

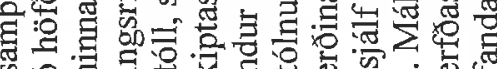

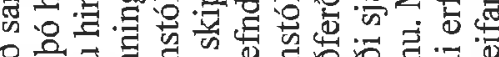

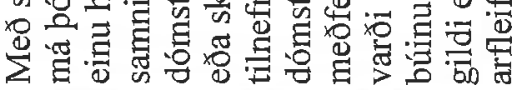

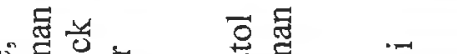

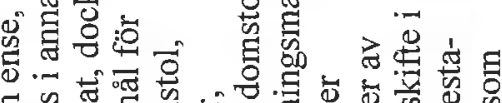

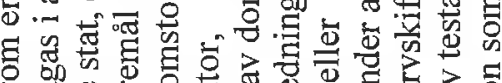

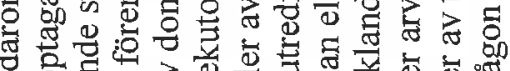
政

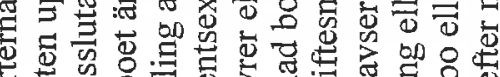
等.7.

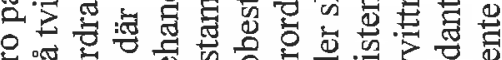

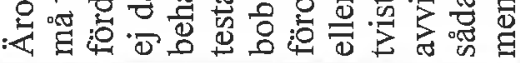
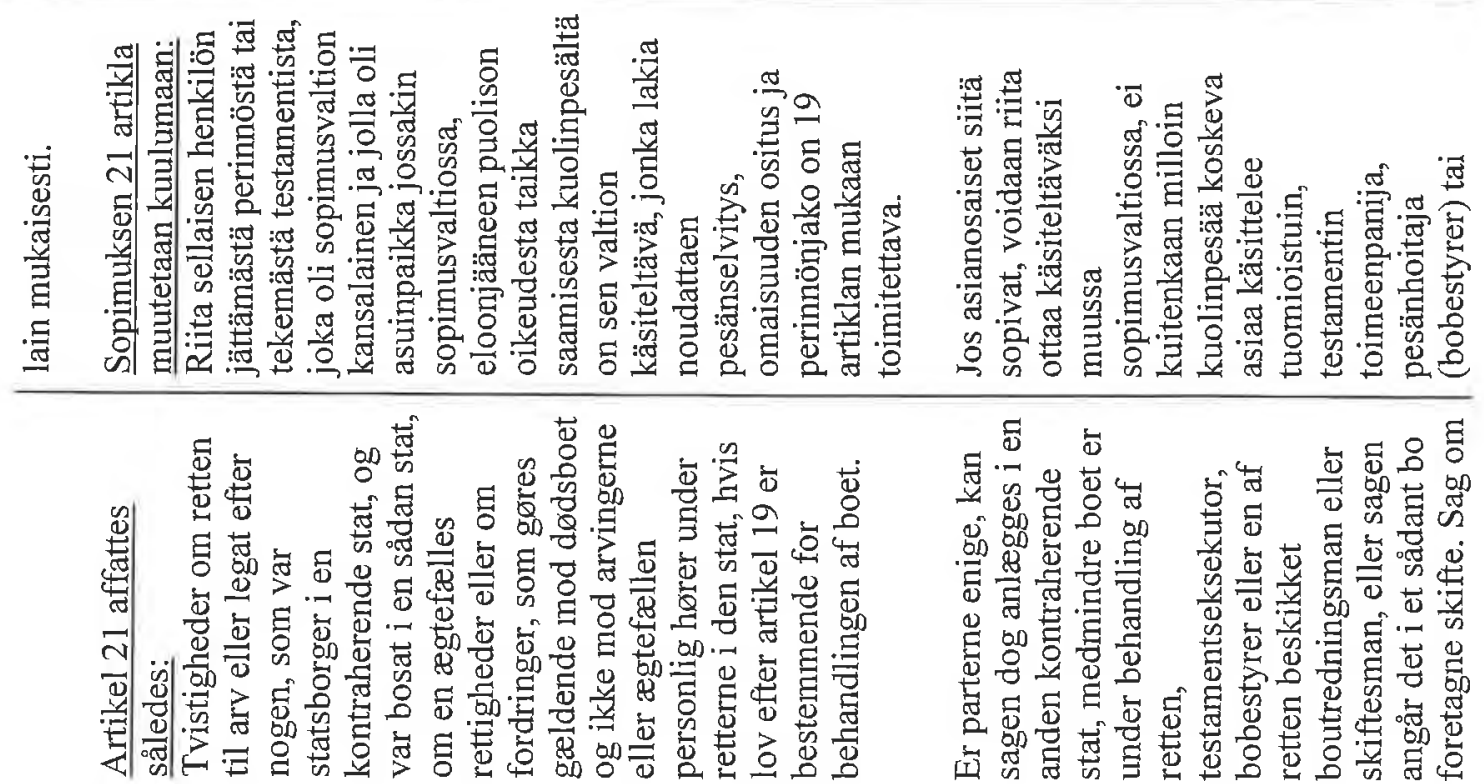


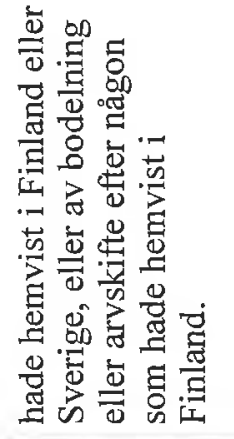

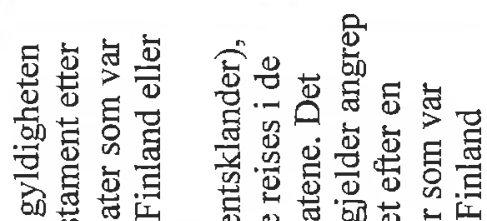

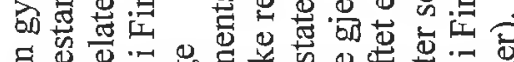

ह5

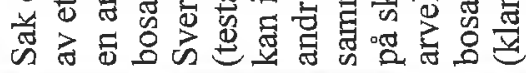
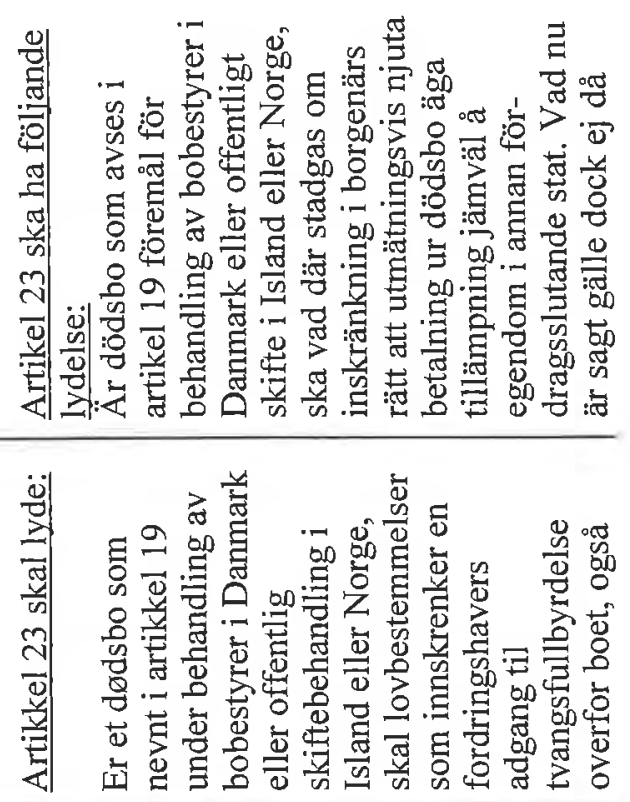

장

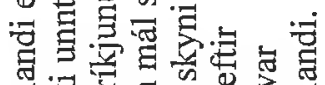

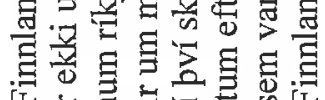

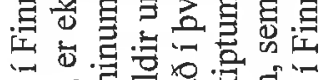

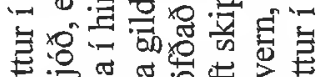

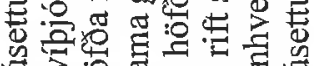

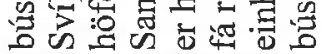

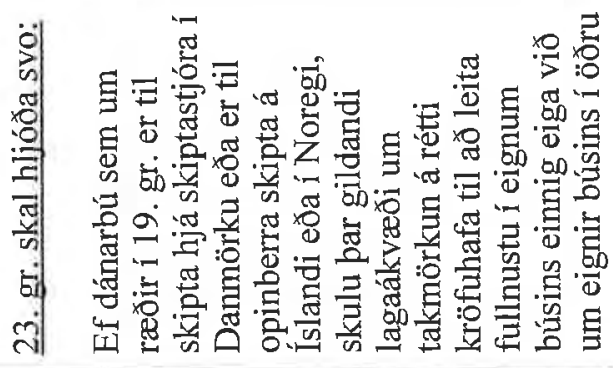

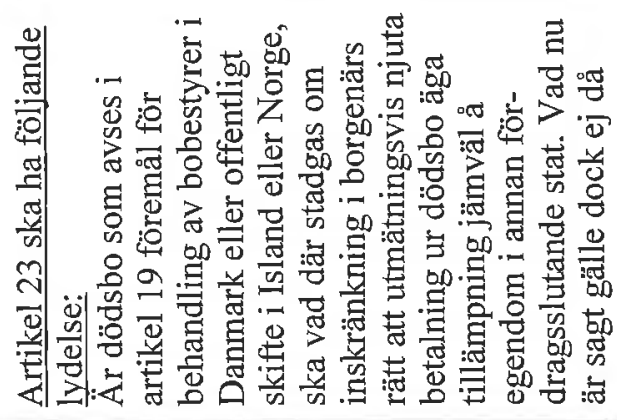

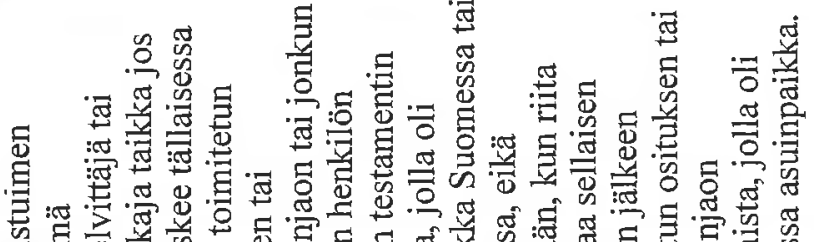

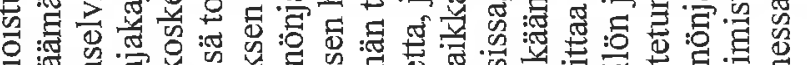

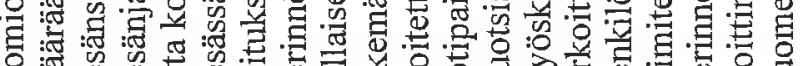

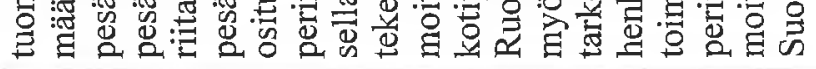
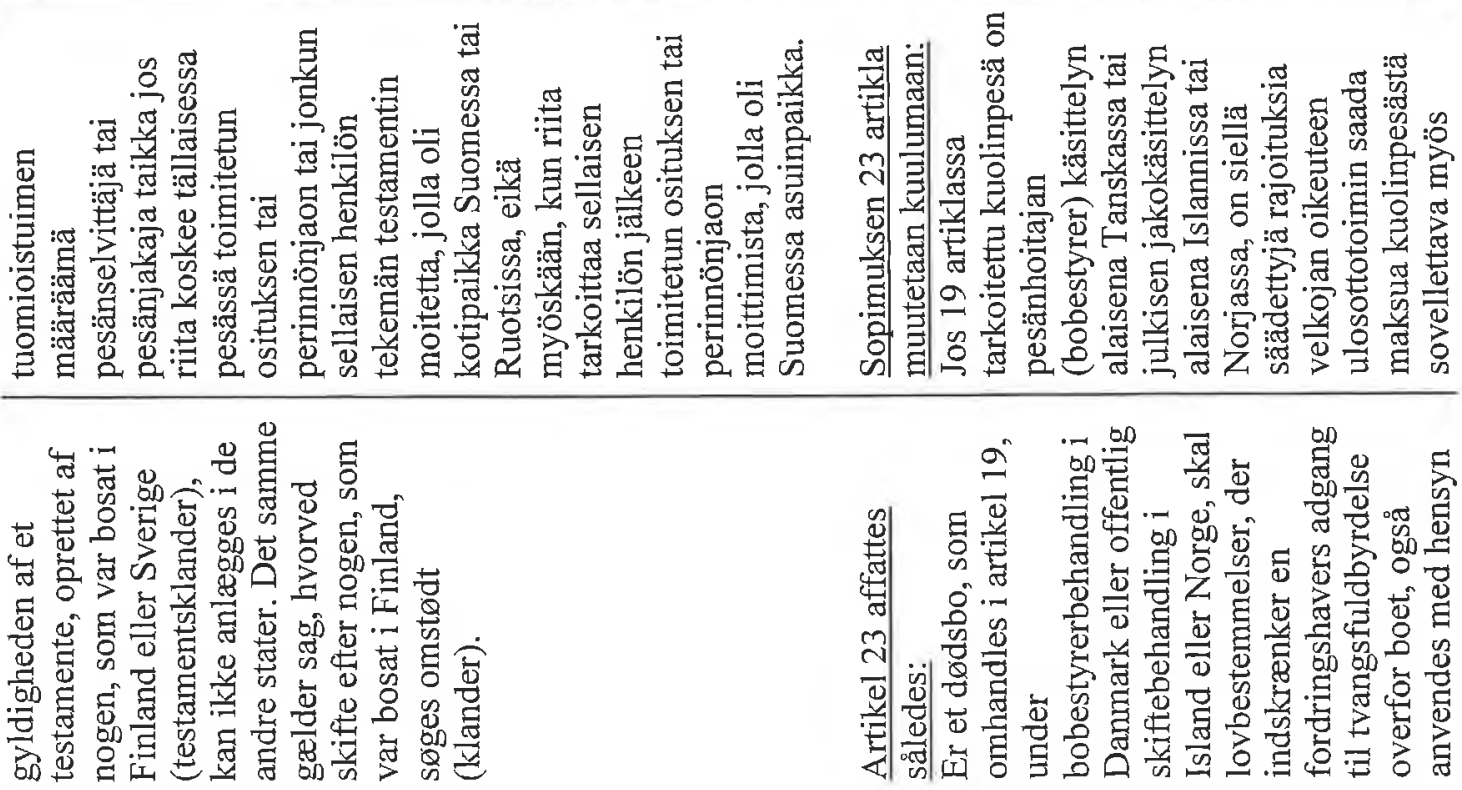

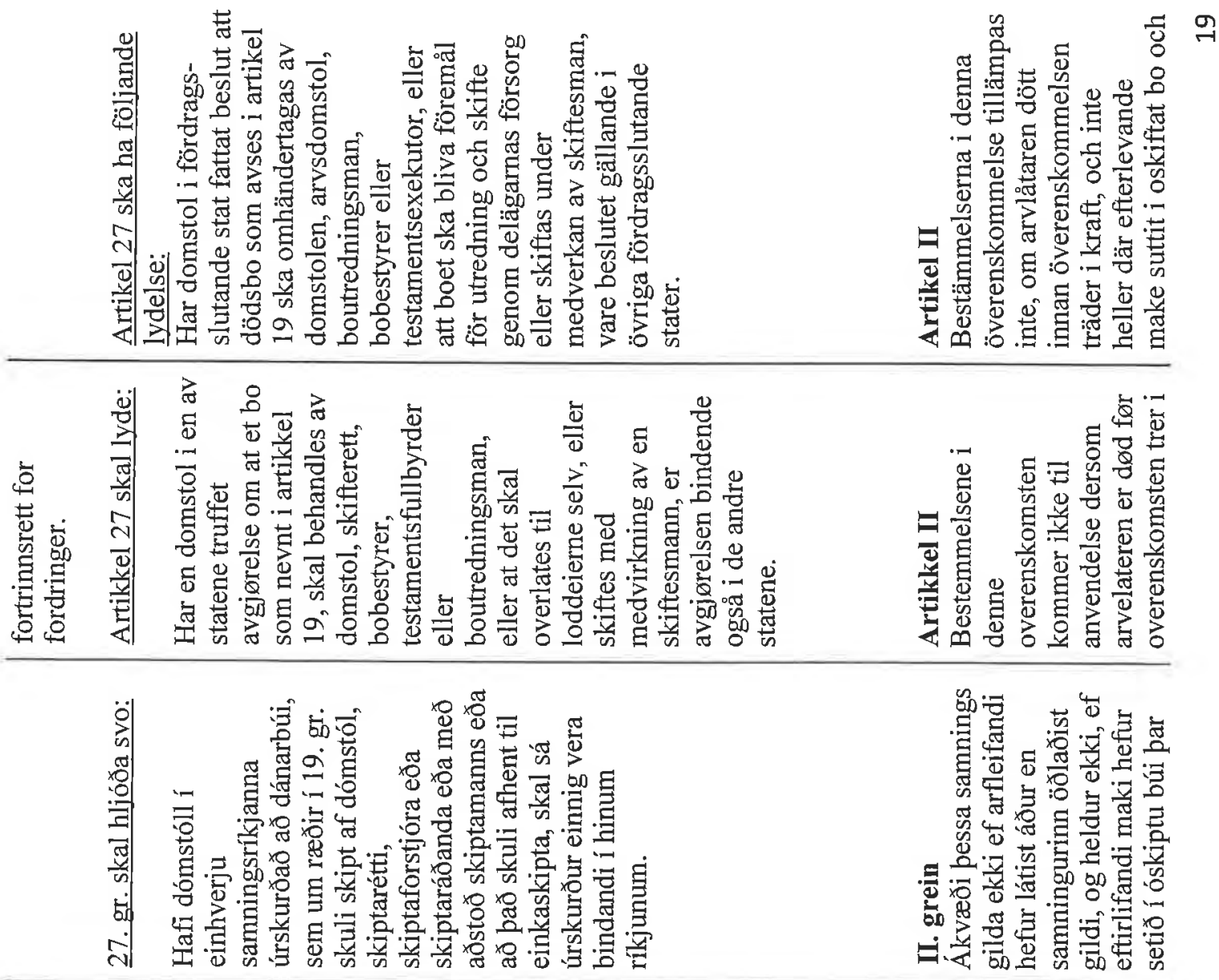

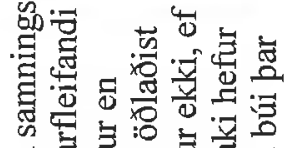

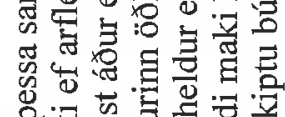

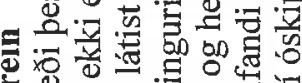
of of

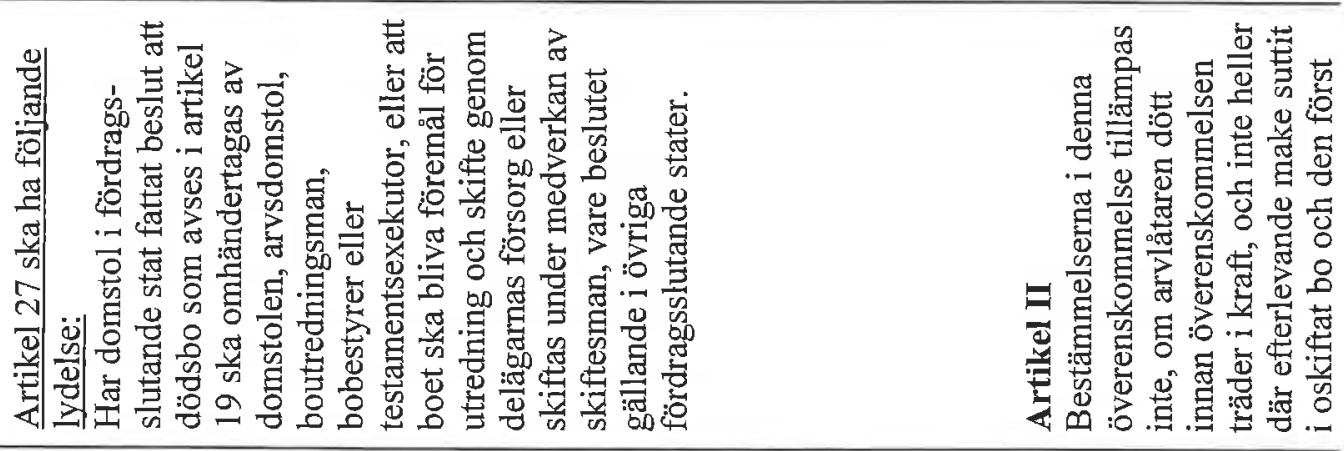

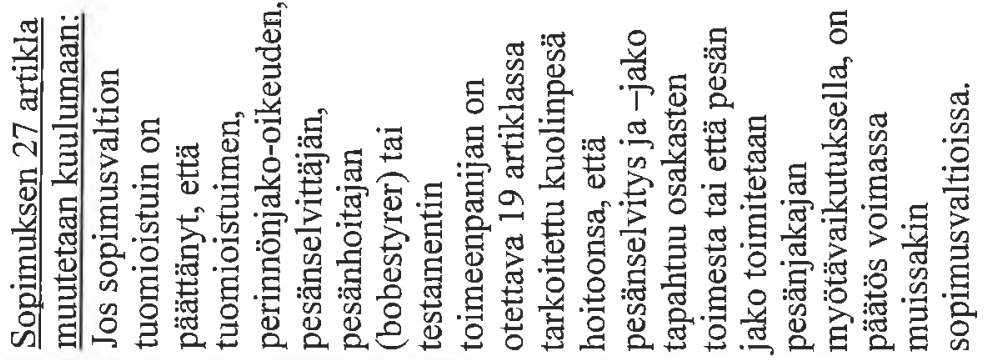

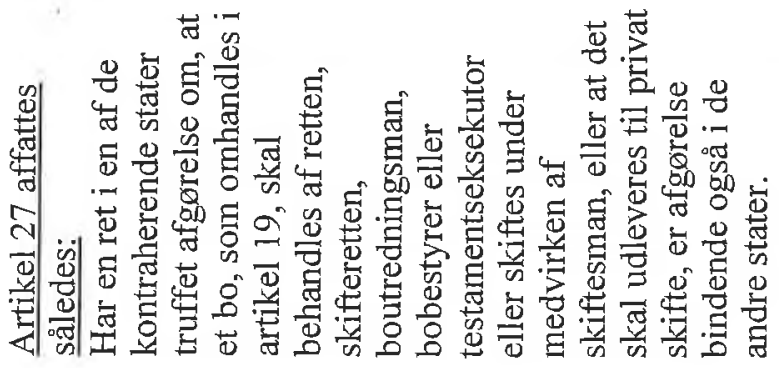

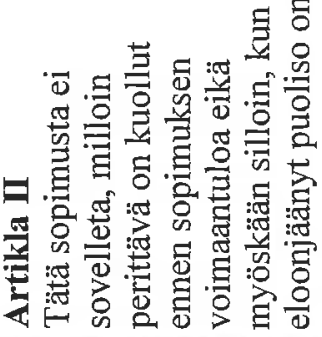

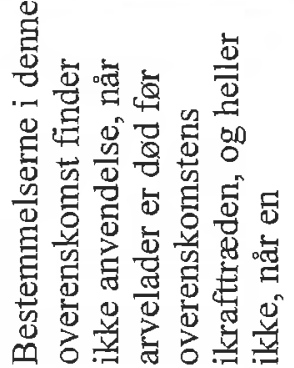




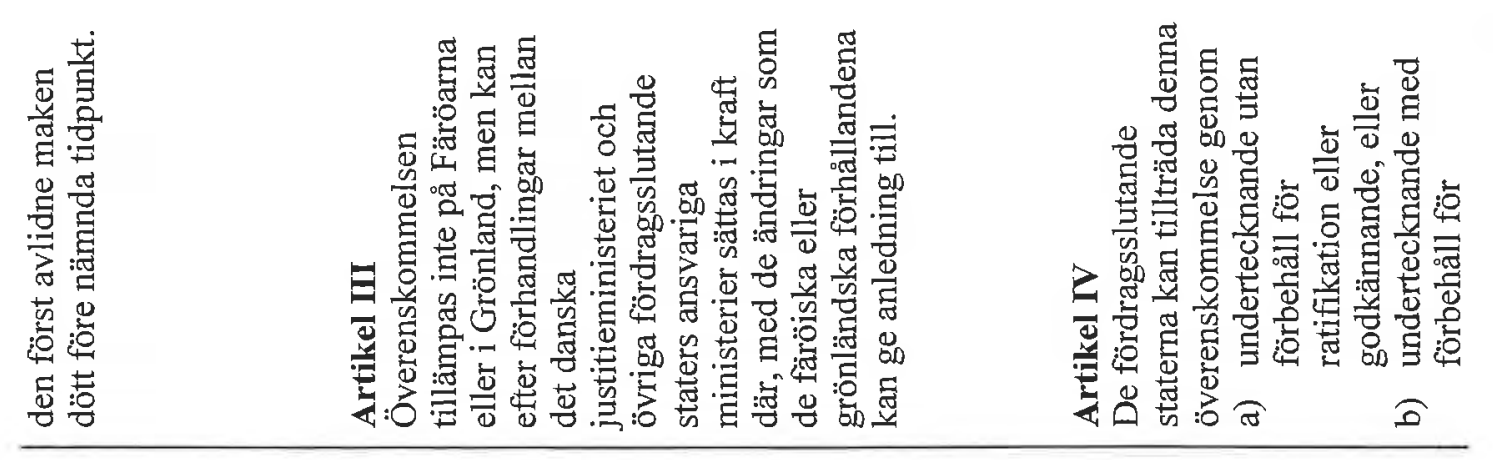

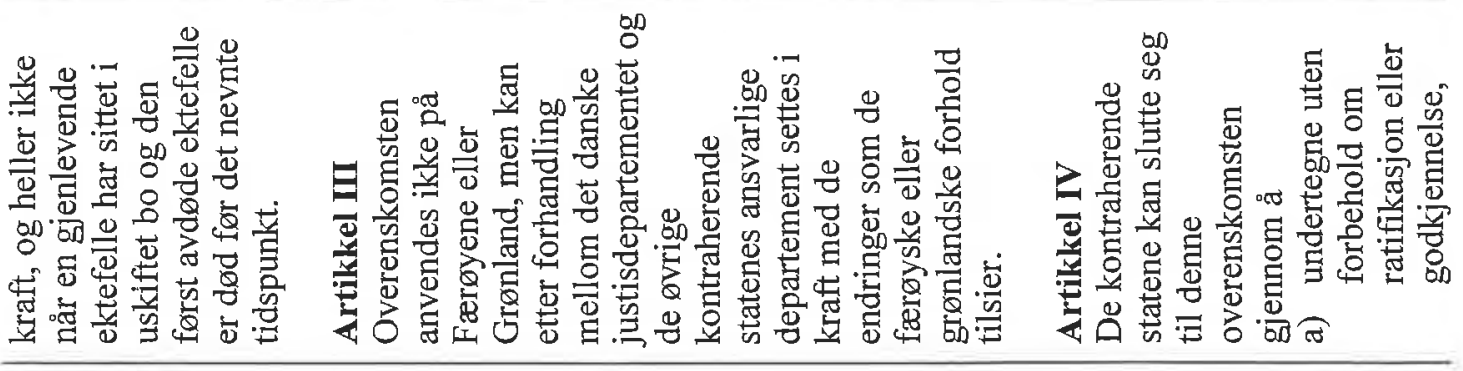

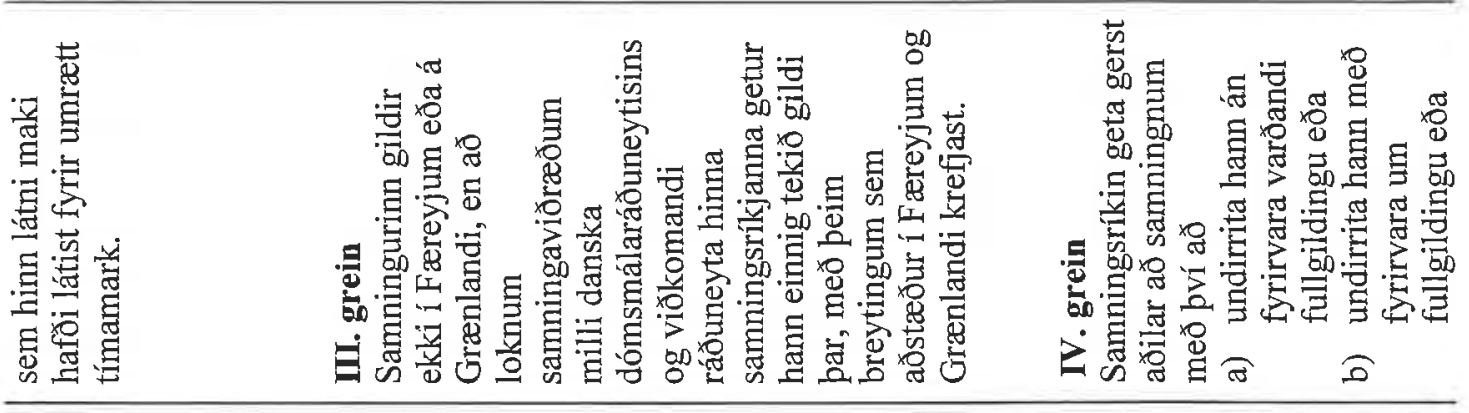
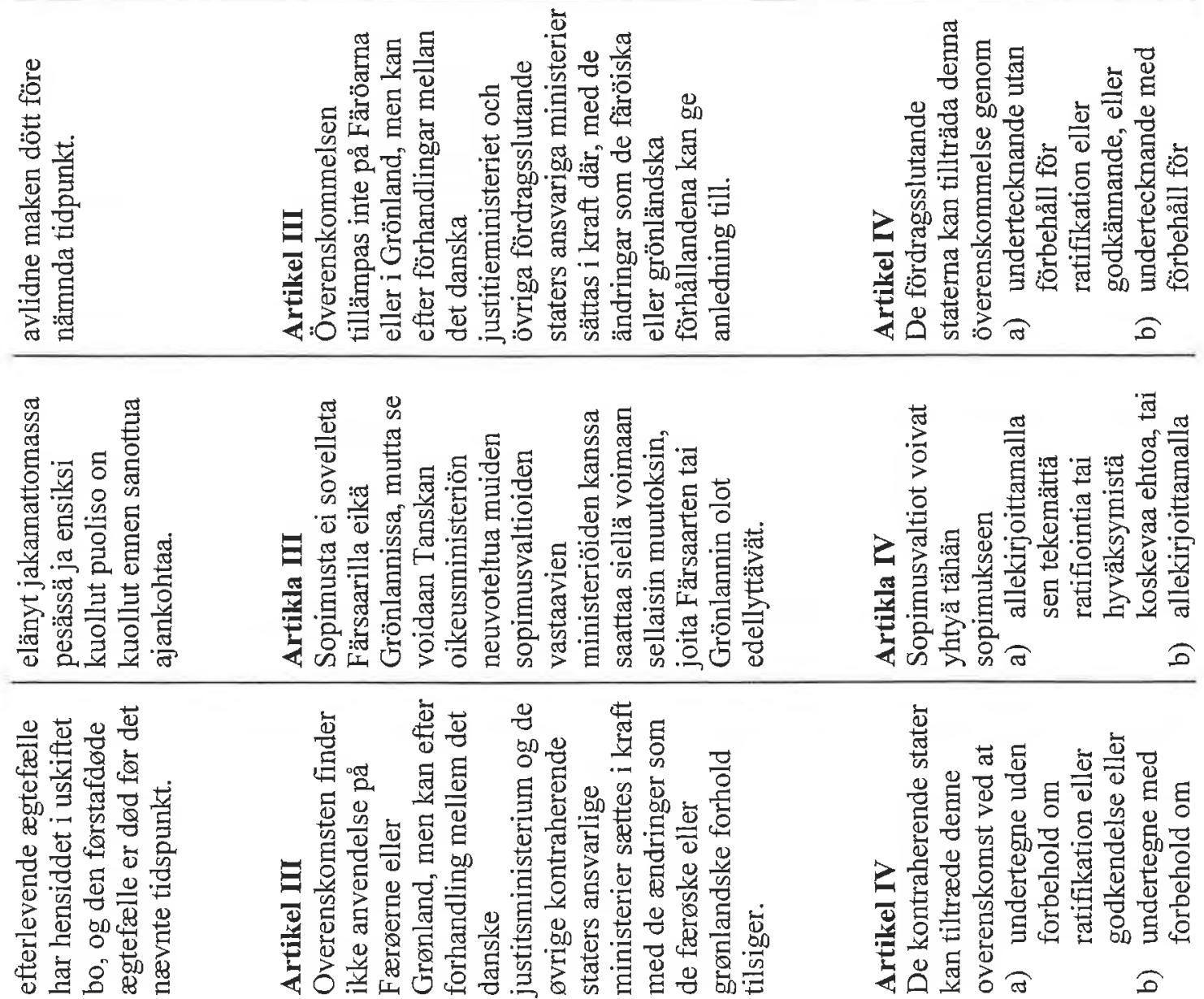

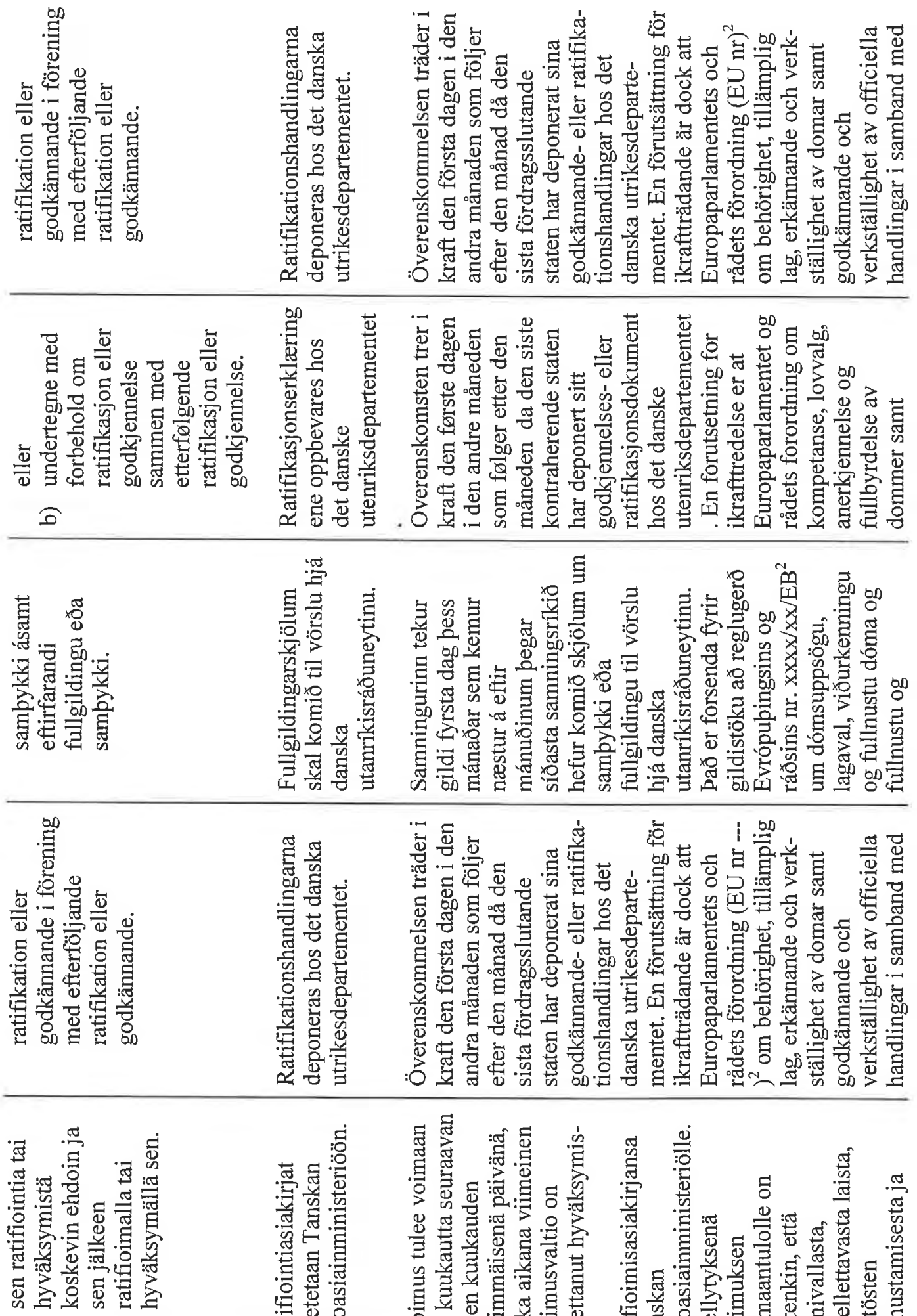

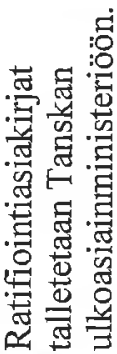
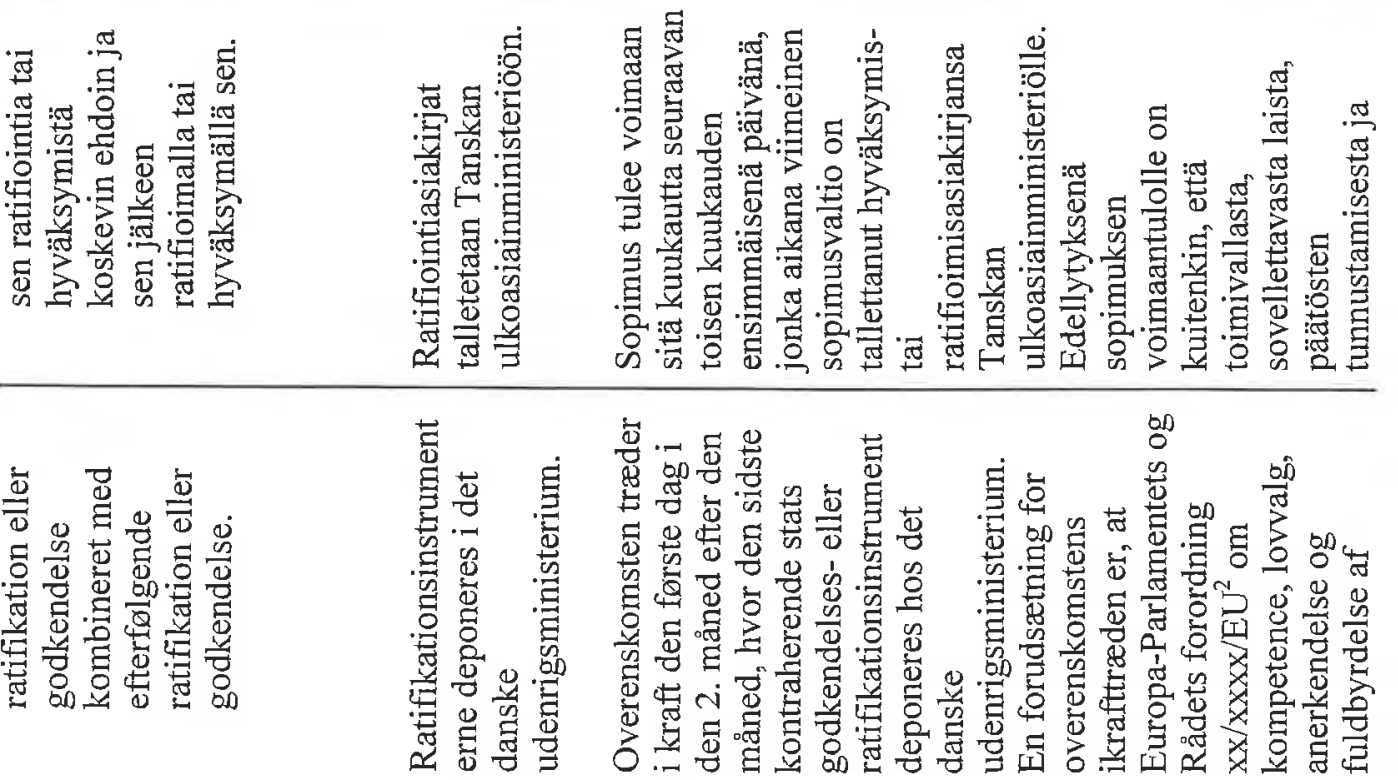

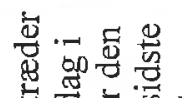

bD

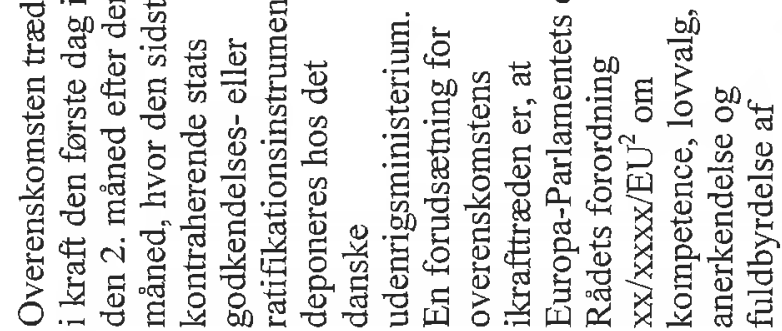



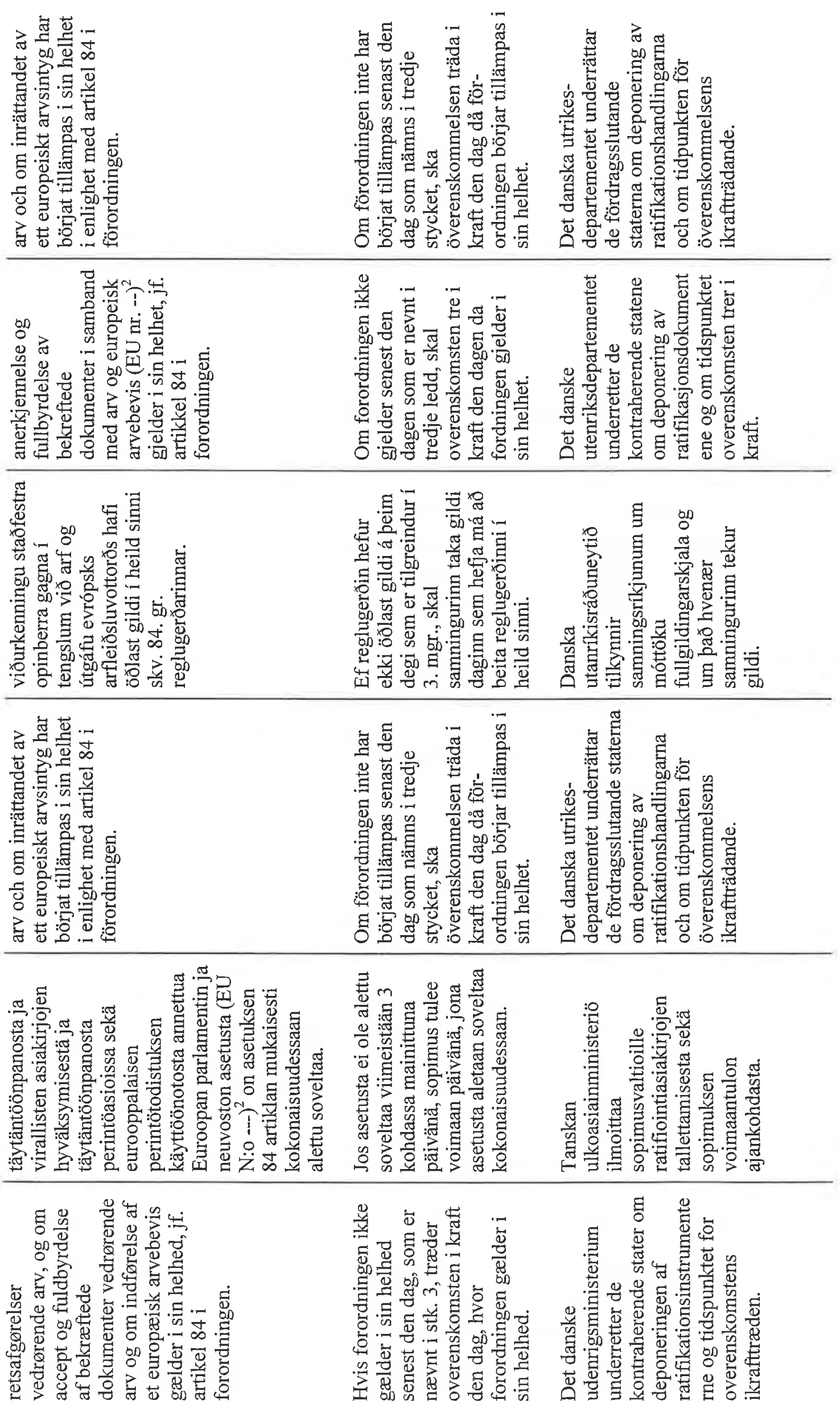

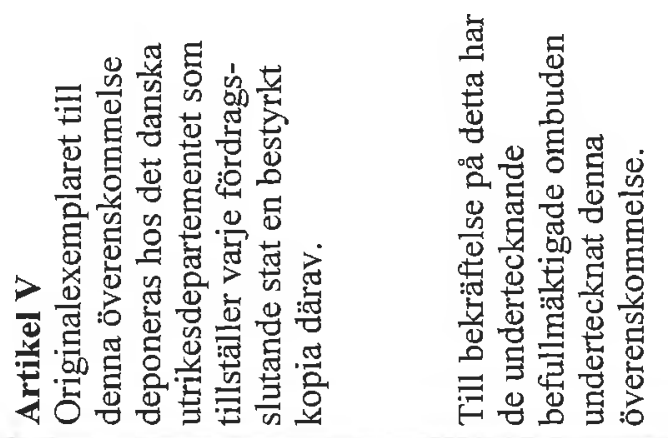

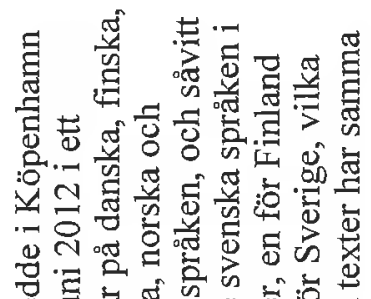

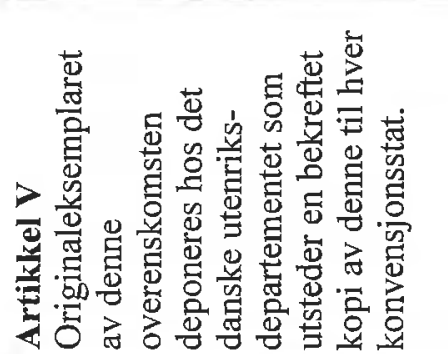

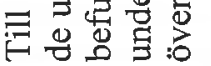

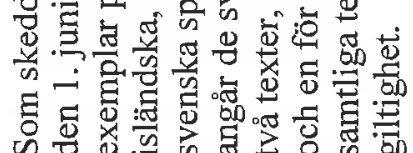

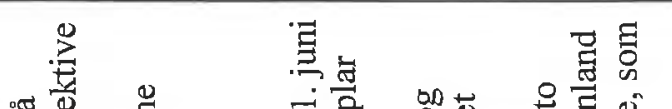

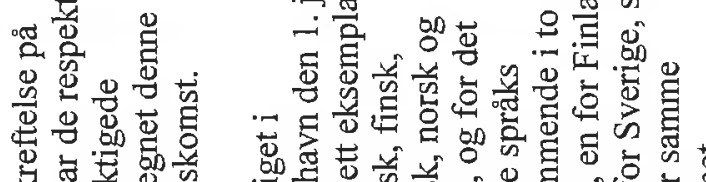

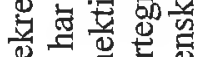

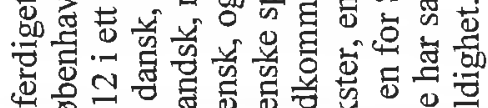

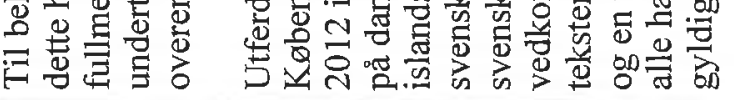

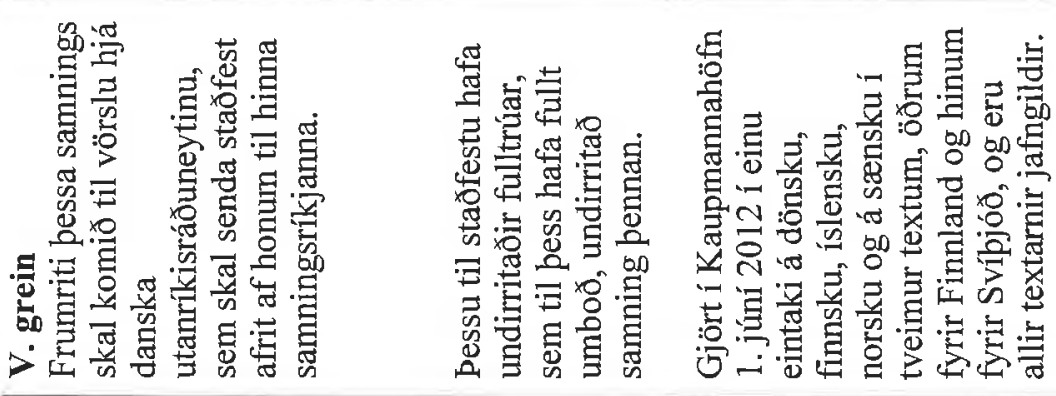
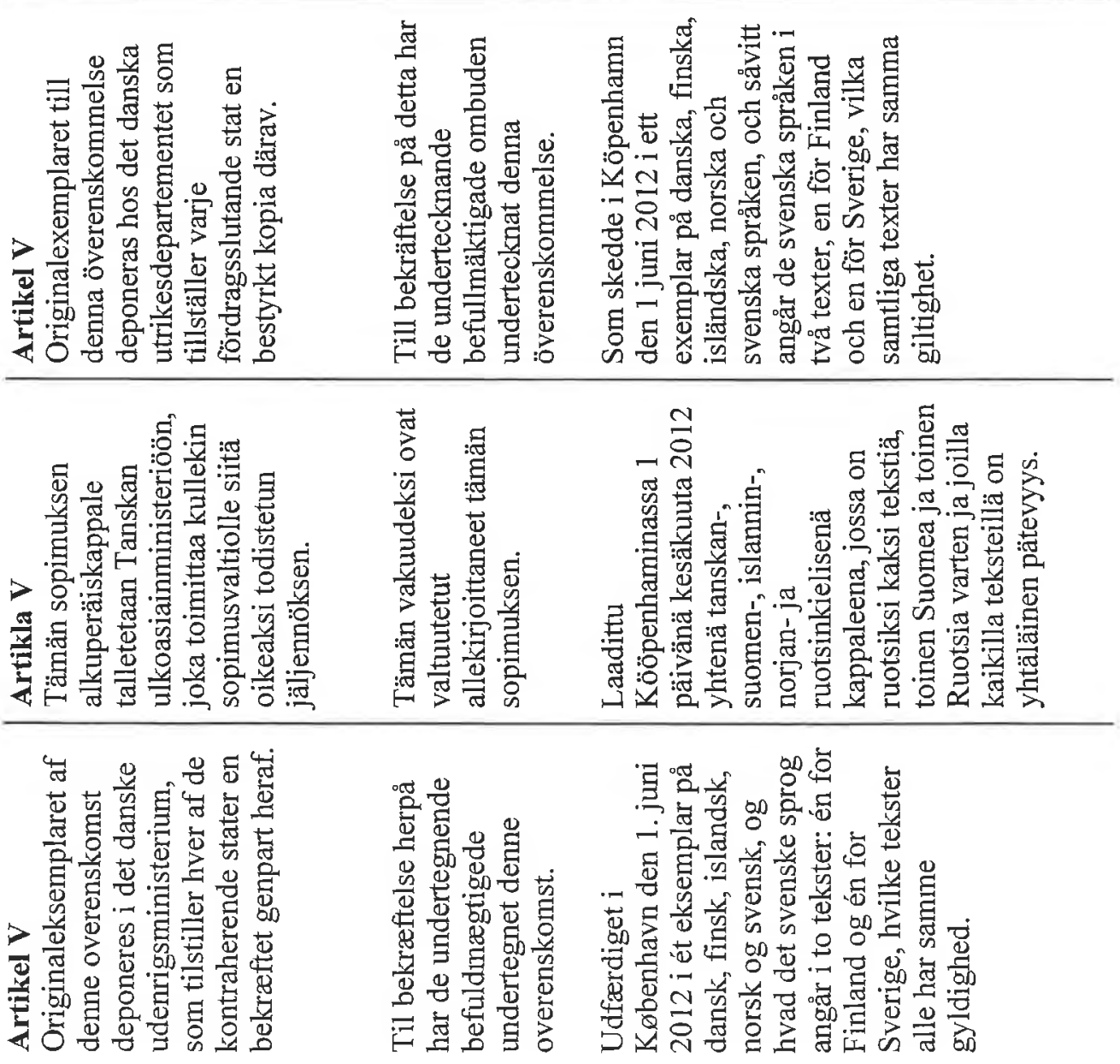

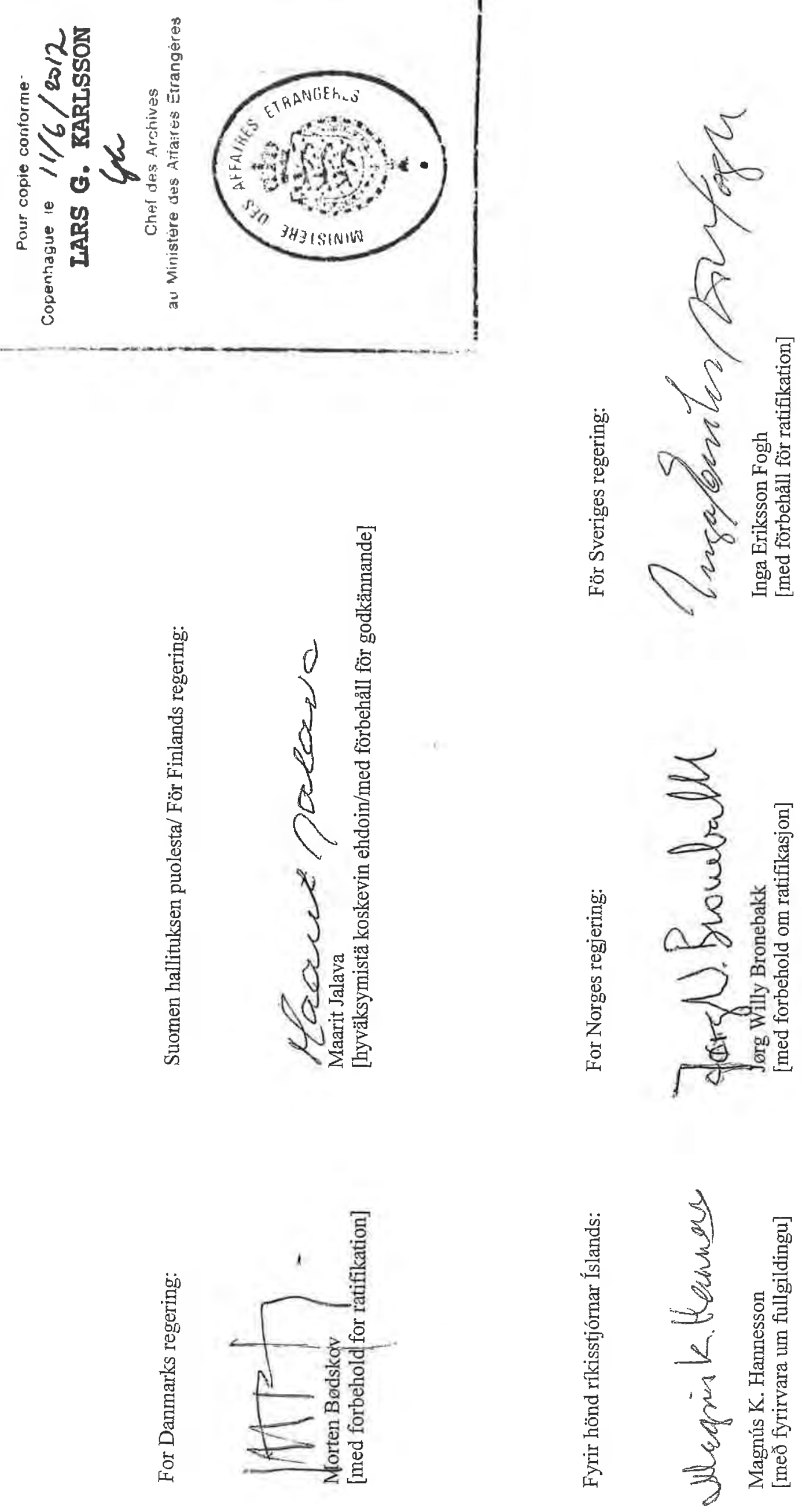
Nordiska ministerrådet

Ved Stranden 18

DK-1061 København K

www.norden.org

Den nordiska konventionen om arv, testamente och boutredning (antagen i Köpenhamn 19.11.1934)

Den 1 juni 2012 undertecknades en överenskommelse om ändring av konventionen mellan Sverige, Danmark, Finland, Island och Norge undertecknad i Köpenhamn den 19 november 1934 om arv, testamente och boutredning (den nordiska arvskonventionen). Ändringsöverenskommelsen byggde på förslag från den nordiska expertgruppen för familjerättsfrågor, som består av representanter för ansvariga departement i de nordiska länderna. Publikationen innehåller resultatet av expertgruppens överväganden i form av en förklaranderapport."

TemaNord 2013:528

ISBN 978-92-893-2541-7

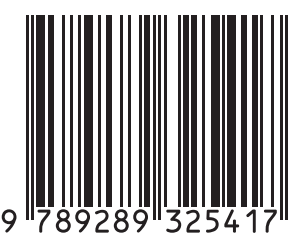

